\title{
Catalytic Asymmetric Hydrogenation of 2,3,5-Trisubstituted Pyrroles
}

\author{
Ryoichi Kuwano, Manabu Kashiwabara, Masato Ohsumi, and Hiroki Kusano \\ Department of Chemistry, Graduate School of Sciences, Kyushu University, 6-10-1 Hakozaki, Higashi-ku, \\ Fukuoka 812-8581, Japan
}

\section{Supporting Information}

General and Materials. All NMR spectra were measured with Bruker AVANCE 400 (9.4 T magnet) spectrometer. In ${ }^{1} \mathrm{H}$ NMR spectra, chemical shifts (ppm) referenced to internal tetramethylsilane $(0.00 \mathrm{ppm}$, in $\left.\mathrm{CDCl}_{3}\right)$ or residual solvent $\left(7.15 \mathrm{ppm}\right.$, in $\left.\mathrm{C}_{6} \mathrm{D}_{6}\right)$. In ${ }^{13} \mathrm{C}$ NMR spectra, chemical shifts (ppm) referenced to the carbon signal of the deuterated solvents $\left(77.0 \mathrm{ppm}\right.$ in $\mathrm{CDCl}_{3}$ or $128.0 \mathrm{ppm}$ in $\left.\mathrm{C}_{6} \mathrm{D}_{6}\right)$. IR spectra were measured with JASCO FT/IR-4100. Elemental and high resolution mass (HRMS) analyses were performed by Service Centre of Elementary Analysis of Organic Compounds and Institute for Materials Chemistry and Engineering (ICME) in Kyushu University, respectively. Flash column chromatographies and medium-pressure liquid chromatographies (MPLC) were performed with silica gel 60 (230-400 mesh, Merck) and C.I.G. pre-packed column CPS-223L-1 (Kusano, Tokyo, Japan), respectively.

Acetonitrile $(\mathrm{MeCN})$, ethyl acetate $(\mathrm{EtOAc})$, 2-propanol $(i-\mathrm{PrOH})$, and triethylamine $\left(\mathrm{Et}_{3} \mathrm{~N}\right)$ were dried with calcium hydride. Methanol $(\mathrm{MeOH})$ was dried with $\mathrm{Mg}(\mathrm{OMe})_{2}$. These solvents and reagents were distilled under nitrogen atmosphere. Tetrahydrofuran (THF) (HPLC grade, without inhibitor) was deoxidized by purging with nitrogen for $30 \mathrm{~min}$ and was dried with an alumina column system (GlassContour Co.). $\quad \mathrm{Ru}\left(\eta^{3} \text {-methallyl) }\right)_{2}(\operatorname{cod}),{ }^{1} \quad(S, S)-(R, R)$-PhTRAP, ${ }^{2}$ Methyl $N$-(tert-butoxycarbonyl)pyrrole-2-carboxylate (1a), ${ }^{3}$ were prepared according to literature procedures. All other materials were purchased and used without further purification.

\section{Preparations of $N$-Boc Pyrroles 1.}

\section{General Procedure of $\mathrm{N}$-Boc Protection of Pyrroles.}

Under nitrogen atmosphere, $(\mathrm{Boc})_{2} \mathrm{O}(2.40 \mathrm{~g}, 11 \mathrm{mmol})$ was added to a solution of a pyrrole $(10 \mathrm{mmol})$ and DMAP $(61 \mathrm{mg}, 0.5 \mathrm{mmol})$ in dry $\mathrm{MeCN}(3.3 \mathrm{ml})$ at room temperature. The mixture was stirred until the pyrrole disappeared completely or the reaction mixture ceased evolving carbon dioxide (monitored by a bubbler tube). After water was added, the resulting mixture was extracted with EtOAc. The organic phase was washed with brine, dried with $\mathrm{Na}_{2} \mathrm{SO}_{4}$, and evaporated under reduced pressure. The residue was purified with a flash column chromatography (EtOAc/hexane) to give the desired $N$-Boc-pyrroles 1. 
Methyl $N$-(tert-Butoxycarbonyl)-3,5-dimethylpyrrole-2-carboxylate (1b).

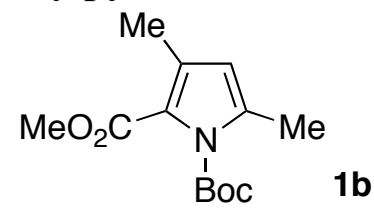

The general procedure was followed with use of methyl 3,5-dimethylpyrrole-2-carboxylate ${ }^{4}$ (1.25 g, 8.2 mmol). The reaction was conducted for $17 \mathrm{~h}$. The crude product was purified with a flash column chromatography $($ EtOAc/hexane $=1 / 10)$ to give $\mathbf{1 b}(1.47 \mathrm{~g}, 71 \%$ yield $)$ as pale yellow oil: ${ }^{1} \mathrm{H}$ NMR (400 $\mathrm{MHz}_{2} \mathrm{CDCl}_{3}$, TMS) $\delta 1.56(\mathrm{~s}, 9 \mathrm{H}), 2.20(\mathrm{~s}, 3 \mathrm{H}), 2.32(\mathrm{~s}, 3 \mathrm{H}), 3.82(\mathrm{~s}, 3 \mathrm{H}), 5.77(\mathrm{~s}, 1 \mathrm{H}) ;{ }^{13} \mathrm{C}\left\{{ }^{1} \mathrm{H}\right\} \mathrm{NMR}(100$ $\left.\mathrm{MHz}, \mathrm{CDCl}_{3}\right) \delta 12.4,14.0,27.6,51.3,84.2,113.0,120.9,130.9,135.8,149.7,161.8$; IR (neat) 2981, 1750, 1712, 1321, 1227, 1162, $1109 \mathrm{~cm}^{-1}$; Anal. Calcd for $\mathrm{C}_{13} \mathrm{H}_{19} \mathrm{NO}_{4}$ : C, 61.64; H, 7.56; N, 5.53. Found: C, 61.70; H, 7.59; N, 5.57.

Methyl $N$-(tert-Butoxycarbonyl)-2,5-dimethylpyrrole-3-carboxylate (1c).

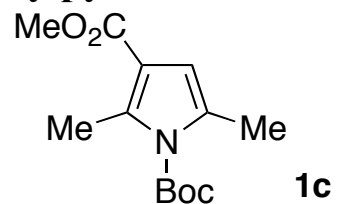

Methyl 2,5-dimethylpyrrole-3-carboxylate ${ }^{6}$ was prepared by the modified procedure reported by Roomi and MacDonald. ${ }^{7}$

Chloroacetone $(4.0 \mathrm{ml}, d 1.16 \mathrm{~g} / \mathrm{ml}, 50 \mathrm{mmol})$ was added carefully to a mixture of methyl acetoacetate (5.4 $\mathrm{ml}, d 1.07 \mathrm{~g} / \mathrm{ml}, 50 \mathrm{mmol}), 28 \% \mathrm{NH}_{3} a q .(25 \mathrm{ml})$, and water $(25 \mathrm{ml})$ at room temperature. After stirred for $17 \mathrm{~h}$, the mixture was extracted five times with EtOAc. The combined organic phase was successively washed with $10 \% \mathrm{NaOH}$ aq. and then with $5 \% \mathrm{HCl}$ aq. The resulting solution was dried with $\mathrm{Na}_{2} \mathrm{SO}_{4}$ and then evaporated under reduced pressure. The residue was purified with a flash column chromatography $($ EtOAc/hexane $=1 / 2)$ to give the desired product $(1.54 \mathrm{~g}, 20 \%)$ as pale yellow oil: ${ }^{1} \mathrm{H} \mathrm{NMR}(400 \mathrm{MHz}$, $\left.\mathrm{CDCl}_{3}, \mathrm{TMS}\right) \delta 2.19$ (s, 3H), 2.48 (s, 3H), 3.78 (s, 3H), 6.18 (d, J=2.7 Hz, 1H), 7.70-8.30 (br, 1H).

The general procedure of $N$-Boc protection was followed with use of the pyrrole prepared above $(1.53 \mathrm{~g}$, $10 \mathrm{mmol}$ ). The reaction was conducted for $9 \mathrm{~h}$. The crude product was purified with a flash column chromatography $($ EtOAc/hexane $=1 / 10)$ to give $1 \mathrm{c}(2.11 \mathrm{~g}, 83 \%$ yield $)$ as a colorless solid: ${ }^{1} \mathrm{H}$ NMR (400 $\left.\mathrm{MHz}, \mathrm{CDCl}_{3}, \mathrm{TMS}\right) \delta 1.61(\mathrm{~s}, 9 \mathrm{H}), 2.34(\mathrm{~s}, 3 \mathrm{H}), 2.71(\mathrm{~s}, 3 \mathrm{H}), 3.79(\mathrm{~s}, 3 \mathrm{H}), 6.22(\mathrm{~s}, 1 \mathrm{H}) ;{ }^{13} \mathrm{C}\left\{{ }^{1} \mathrm{H}\right\} \mathrm{NMR}(100$ $\mathrm{MHz}, \mathrm{CDCl}_{3}$ ) $\delta 14.0,15.8,28.0,51.0,84.6,110.8,114.0,130.2,138.2,149.9,165.5$; IR (nujor) 2979, 1750, 1713, 1335, 1278, 1214, 1171, 1151, $1068 \mathrm{~cm}^{-1}$; Anal. Calcd for $\mathrm{C}_{13} \mathrm{H}_{19} \mathrm{NO}_{4}: \mathrm{C}, 61.64 ; \mathrm{H}, 7.56 ; \mathrm{N}, 5.53$. Found: C, 61.59; H, 7.57; N, 5.55. 


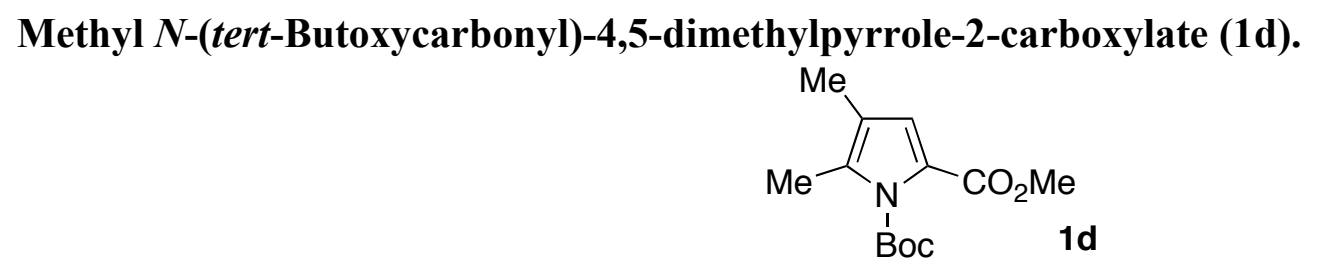

Methyl 4,5-dimethylpyrrole-2-carboxylate was prepared by the modified procedure reported by Wallace. ${ }^{8}$ Under nitrogen atmosphere, ethyl formate $(14.5 \mathrm{ml}, d 0.92 \mathrm{~g} / \mathrm{ml}, 180 \mathrm{mmol})$ was added to a solution of 2-butanone $(10.7 \mathrm{ml}, d 0.81 \mathrm{~g} / \mathrm{ml}, 120 \mathrm{mmol})$ in dry THF $(14 \mathrm{ml})$ at $0^{\circ} \mathrm{C}$. A solution of sodium tert-butoxide $(13.8 \mathrm{~g}, 144 \mathrm{mmol})$ in dry THF $(36 \mathrm{ml})$ was added dropwise to the mixture at $0^{\circ} \mathrm{C}$ for $2 \mathrm{~h}$. After the mixture was stirred at room temperature for $18 \mathrm{~h}$, the colorless precipitation was formed in the yellow solution. The precipitation was collected with filtration, washed with dry THF, and dried in vacuo to give sodium 2-methyl-3-oxobutanalate (12.2 g, 83\%).

A solution of the precipitation $(11.7 \mathrm{~g}, 96 \mathrm{mmol})$ in water $(31 \mathrm{ml})$ was added to a mixture of methyl 2-(hydroxyimino)-3-oxobutanoate 9 (14.5 g, $100 \mathrm{mmol})$, 1,4-dioxane (29 ml), acetic acid (15 ml) and water $(71 \mathrm{ml})$. Six portions of zinc powder $(10.2 \mathrm{~g}, 160 \mathrm{mg}$-atoms $)$ were added to the mixture at $60^{\circ} \mathrm{C}$ and intervals of $15 \mathrm{~min}$. After stirred at $60^{\circ} \mathrm{C}$ for $15 \mathrm{~min}$ and then at $80^{\circ} \mathrm{C}$ for $1.5 \mathrm{~h}$, the resulting mixture was diluted with EtOAc, filtered through a Celite pad, and then extracted four times with EtOAc. The combined organic phase was dried with $\mathrm{Na}_{2} \mathrm{SO}_{4}$, and evaporated under reduced pressure. The residue was purified with a flash column chromatography (EtOAc/hexane $=1 / 10)$. The resulting crude product was recrystallized from EtOAc-hexane to give methyl 4,5-dimethylpyrrole-2-carboxylate (6.05 $\mathrm{g}, 41 \%)$ as colorless crystals: ${ }^{1} \mathrm{H}$ NMR $\left(400 \mathrm{MHz}, \mathrm{CDCl}_{3}\right.$, TMS) $\delta 2.00(\mathrm{~s}, 3 \mathrm{H}), 2.20(\mathrm{~s}, 3 \mathrm{H}), 3.81(\mathrm{~s}, 3 \mathrm{H}), 6.66(\mathrm{~d}, J=$ $2.4 \mathrm{~Hz}, 1 \mathrm{H}), 8.48-8.78$ (br, $1 \mathrm{H})$.

The general procedure of $N$-Boc protection was followed with use of the pyrrole prepared above $(0.766 \mathrm{~g}$, $5.0 \mathrm{mmol}$ ). The reaction was conducted for $14 \mathrm{~h}$. The crude product was purified with a flash column chromatography $($ EtOAc/hexane $=1 / 10)$ to give $1 \mathbf{d}(1.15 \mathrm{~g}, 91 \%$ yield $)$ as colorless oil: ${ }^{1} \mathrm{H}$ NMR $(400 \mathrm{MHz}$, $\left.\mathrm{CDCl}_{3}, \mathrm{TMS}\right) \delta 1.57(\mathrm{~s}, 9 \mathrm{H}), 1.97(\mathrm{~s}, 3 \mathrm{H}), 2.27(\mathrm{~s}, 3 \mathrm{H}), 3.80(\mathrm{~s}, 3 \mathrm{H}), 6.66(\mathrm{~s}, 1 \mathrm{H}) ;{ }^{13} \mathrm{C}\left\{{ }^{1} \mathrm{H}\right\} \mathrm{NMR}(100 \mathrm{MHz}$, $\left.\mathrm{CDCl}_{3}\right) \delta 10.8,11.3,27.5,51.4,84.4,117.5,121.1,122.6,133.2,149.8,161.0$; IR (neat) 2981, 1749, 1714, 1370, 1315, 1219, 1151, $1087 \mathrm{~cm}^{-1}$; Anal. Calcd for $\mathrm{C}_{13} \mathrm{H}_{19} \mathrm{NO}_{4}$ : C, 61.64; H, 7.56; N, 5.53. Found: C, 61.83; H, 7.58; N, 5.47 .

\section{Methyl $N$-(tert-Butoxycarbonyl)-4,5,6,7-tetrahydroindole-2-carboxylate (1e).}

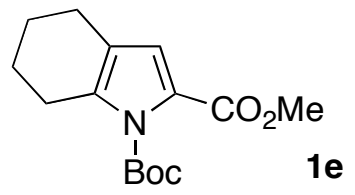

The general procedure was followed with use of methyl 4,5,6,7-tetrahydroindole-2-carboxylate ${ }^{5}$ (627 mg, $3.5 \mathrm{mmol}$ ). The reaction was conducted for $18 \mathrm{~h}$. The crude product was purified with a flash column chromatography $($ EtOAc/hexane $=1 / 10)$ to give 1 e $(901 \mathrm{mg}, 92 \%$ yield $)$ as a colorless solid: ${ }^{1} \mathrm{H}$ NMR $(400$ 
$\left.\mathrm{MHz}, \mathrm{CDCl}_{3}, \mathrm{TMS}\right) \delta 1.57(\mathrm{~s}, 9 \mathrm{H}), 1.67-1.75(\mathrm{~m}, 2 \mathrm{H}), 1.75-1.83(\mathrm{~m}, 4 \mathrm{H}), 2.43(\mathrm{t}, J=6.0 \mathrm{~Hz}, 2 \mathrm{H}), 2.73(\mathrm{t}, J$ $=6.2 \mathrm{~Hz}, 2 \mathrm{H}), 3.80(\mathrm{~s}, 3 \mathrm{H}), 6.65(\mathrm{~s}, 1 \mathrm{H}) ;{ }^{13} \mathrm{C}\left\{{ }^{1} \mathrm{H}\right\} \mathrm{NMR}\left(100 \mathrm{MHz}, \mathrm{CDCl}_{3}\right) \delta$ 22.72, 22.73, 22.9, 23.9, 27.6, 51.5, 84.2, 119.9, 120.2, 123.3, 136.3, 149.3, 161.3; IR (neat) 1746, 1719, $1215 \mathrm{~cm}^{-1}$; Anal. Calcd for $\mathrm{C}_{15} \mathrm{H}_{21} \mathrm{NO}_{4}$ : C, 64.50; H, 7.58; N, 5.01. Found: C, 64.25; H, 7.57; N, 5.02.

\section{N-(tert-Butoxycarbonyl)-3-methyl-5-phenyl-2-propylpyrrole (1f).}

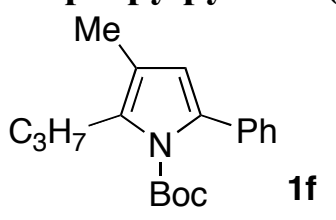

Under nitrogen atmosphere, triethylamine $(4.2 \mathrm{ml}, d 0.726 \mathrm{~g} / \mathrm{ml}, 30 \mathrm{mmol}), 1$-phenyl-2-buten-1-one (8.01 $\mathrm{g}, \quad 55 \mathrm{mmol})$, and butyraldehyde $(3.60 \mathrm{~g}, 50 \mathrm{mmol})$ were added to a solution of 3-benzyl-5-(2-hydroxyethyl)-4-methylthiazolium chloride (2.70 g, $10 \mathrm{mmol})$ in EtOH (70 ml). After stirred at $80^{\circ} \mathrm{C}$ for $67 \mathrm{~h}$, the reaction mixture was evaporated under reduced pressure. The residue was dissolved in EtOAc. The resulting solution was successively washed with $5 \% \mathrm{HCl} a q$., with sat. $\mathrm{NaHCO}_{3} a q$., and twice with water. The organic phase was dried with $\mathrm{MgSO}_{4}$, and then evaporated under reduced pressure. The residue was purified with a flash column chromatography (EtOAc/hexane $=1 / 20)$ to give 3-methyl-1-phenyl-1,4-heptanedione (4.22 g, 39\%) as yellow oil: ${ }^{1} \mathrm{H}$ NMR (400 MHz, $\left.\mathrm{CDCl}_{3}, \mathrm{TMS}\right) \delta 0.94$ (t, $J=7.4 \mathrm{~Hz}, 3 \mathrm{H}), 1.18(\mathrm{~d}, J=7.24 \mathrm{~Hz}, 3 \mathrm{H}), 1.65$ (sextet, $J=7.4 \mathrm{~Hz}, 2 \mathrm{H}), 2.59$ (dt, $J=17.3,7.4 \mathrm{~Hz}, 1 \mathrm{H})$, $2.64(\mathrm{dt}, J=17.3,7.5 \mathrm{~Hz}, 1 \mathrm{H}), 2.92$ (dd, $J=4.5,17.9 \mathrm{~Hz}, 1 \mathrm{H}), 3.23$ (ddq, $J=4.5,8.9,7.2 \mathrm{~Hz}, 1 \mathrm{H}), 3.55$ (dd, $J=8.9,17.9 \mathrm{~Hz}, 1 \mathrm{H}), 7.45(\mathrm{t}, J=7.6 \mathrm{~Hz}, 2 \mathrm{H}), 7.56(\mathrm{dt}, J=7.4,1.2 \mathrm{~Hz}, 1 \mathrm{H}), 7.93-7.98(\mathrm{~m}, 2 \mathrm{H})$.

A solution of 3-methyl-1-phenyl-1,4-heptanedione (4.22 g, $19 \mathrm{mmol})$ and ammonium acetate (12.4 g, 160 mmol) in acetic acid $(25 \mathrm{ml})$ was stirred under reflux for $16 \mathrm{~h}$. After diluted with sat. $\mathrm{NaHCO}_{3} a q$., the resulting mixture was extracted four times with EtOAc. The combined organic layer was dried with $\mathrm{Na}_{2} \mathrm{SO}_{4}$, and then evaporated under reduced pressure. The residue was purified with a flash column chromatography $($ EtOAc/hexane $=1 / 50)$ to give 3-methyl-5-phenyl-2-propylpyrrole $(1.75 \mathrm{~g}, 45 \%)$ as yellow oil: ${ }^{1} \mathrm{H}$ NMR (400 MHz, $\left.\mathrm{CDCl}_{3}, \mathrm{TMS}\right) \delta 0.98(\mathrm{t}, J=7.34 \mathrm{~Hz}, 3 \mathrm{H}), 1.63$ (sextet, $J=7.5 \mathrm{~Hz}, 2 \mathrm{H}$ ), 2.06 (s, 3H), $2.56(\mathrm{t}, J=7.5 \mathrm{~Hz}, 2 \mathrm{H}), 6.29$ (d, $J=2.8 \mathrm{~Hz}, 1 \mathrm{H}), 7.13$ (t, $J=7.3 \mathrm{~Hz}, 1 \mathrm{H}), 7.32$ (t, $J=7.8 \mathrm{~Hz}, 2 \mathrm{H}), 7.38-7.42$ (m, 2H), 7.81-8.01 (br, 1H).

The general procedure of $N$-Boc protection was followed with use of 3-methyl-5-phenyl-2-propylpyrrole (203 mg, $1.0 \mathrm{mmol}$ ). The reaction was conducted for $47 \mathrm{~h}$. The crude product was purified with a flash column chromatography $($ EtOAc/hexane $=1 / 50)$ to give $\mathbf{1 f}(78 \mathrm{mg}, 26 \%$ yield $)$ as pale yellow oil: ${ }^{1} \mathrm{H}$ NMR (400 MHz, $\left.\mathrm{CDCl}_{3}, \mathrm{TMS}\right) \delta 0.96(\mathrm{t}, J=7.4 \mathrm{~Hz}, 3 \mathrm{H}), 1.24$ (s, 9H), 1.59 (sextet, $\left.J=7.5 \mathrm{~Hz}, 2 \mathrm{H}\right), 2.02$ (s, 3H), $2.77(\mathrm{t}, J=7.5 \mathrm{~Hz}, 2 \mathrm{H}), 6.00(\mathrm{~s}, 1 \mathrm{H}), 7.21-7.34(\mathrm{~m}, 5 \mathrm{H}) ;{ }^{13} \mathrm{C}\left\{{ }^{1} \mathrm{H}\right\} \mathrm{NMR}\left(100 \mathrm{MHz}, \mathrm{CDCl}_{3}\right) \delta 11.1,13.9$, 23.6, 27.3, 27.6, 83.0, 114.7, 118.0, 126.4, 127.7, 128.1, 133.1, 133.5, 135.4, 150.3; IR (neat) 2962, 1738, $1321,1149 \mathrm{~cm}^{-1}$; Anal. Calcd for $\mathrm{C}_{19} \mathrm{H}_{25} \mathrm{NO}_{2}$ : C, 76.22; H, 8.42; N, 4.68. Found: C, 76.33; H, 8.50; N, 4.58. 
$N$-(tert-Butoxycarbonyl)-2,3,5-triphenylpyrrole (1g).

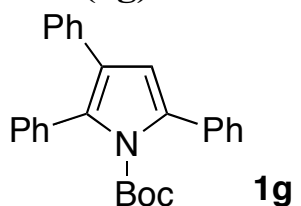

The general procedure was followed with use of 2,3,5-triphenylindole ${ }^{10}$ (881 $\left.\mathrm{mg}, 3.0 \mathrm{mmol}\right)$. The reaction was conducted for $20 \mathrm{~h}$. The crude product was purified with a MPLC $($ EtOAc/hexane $=1 / 5)$ to give 1 g (643 mg, 55\% yield) as a colorless solid: ${ }^{1} \mathrm{H}$ NMR (400 MHz, $\left.\mathrm{CDCl}_{3}, \mathrm{TMS}\right) \delta 1.13(\mathrm{~s}, 9 \mathrm{H}), 6.48(\mathrm{~s}$,

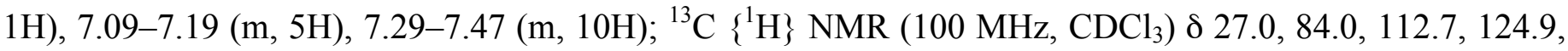
126.0, 127.3, 127.7, 127.96, 127.99, 128.06, 128.12, 128.5, 130.9, 131.2, 133.4, 133.8, 135.1, 135.2, 149.7; IR (thin film) 1749, 1305, $1139 \mathrm{~cm}^{-1}$; Anal. Calcd for $\mathrm{C}_{27} \mathrm{H}_{25} \mathrm{NO}_{2}: \mathrm{C}, 82.00 ; \mathrm{H}, 6.37 ; \mathrm{N}, 3.54$. Found: C, $82.11 ; \mathrm{H}, 6.28 ; \mathrm{N}, 3.54$.

\section{N-(tert-Butoxycarbonyl)-5-(4-fluorophenyl)-2,3-diphenylpyrrole (1h).}

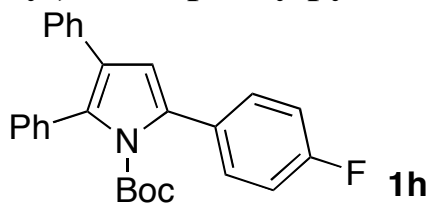

Under nitrogen atmosphere, benzaldehyde $(1.09 \mathrm{~g}, 10 \mathrm{mmol})$ and triethylamine $(630 \mathrm{mg}, 6.2 \mathrm{mmol})$ were added to a solution of 1-(4-fluorophenyl)-3-phenyl-2-propen-1-one (2.49 g, $11 \mathrm{mmol})$ and 3-benzyl-5-(2hydroxyethyl)-4-methylthiazolium chloride $(545 \mathrm{mg}, 2.0 \mathrm{mmol})$ in $\mathrm{EtOH}(5.0 \mathrm{ml})$. After stirred at $80^{\circ} \mathrm{C}$ for $48 \mathrm{~h}$, the reaction mixture was evaporated under reduced pressure. The residue was dissolved in EtOAc. The resulting solution was successively washed with $5 \% \mathrm{HCl} a q$., with sat. $\mathrm{NaHCO}_{3} a q$., and with brine. The organic phase was dried with $\mathrm{MgSO}_{4}$, and then evaporated under reduced pressure. The residue was purified with a flash column chromatography (EtOAc/hexane $=1 / 10$ ) to give 4-(4-fluorophenyl)-1,2diphenyl-1,4-butanedione (2.03 g, 59\%) as a colorless solid: ${ }^{1} \mathrm{H}$ NMR (400 MHz, $\left.\mathrm{CDCl}_{3}, \mathrm{TMS}\right) \delta 3.26$ (dd, $J$ $=3.7,17.9 \mathrm{~Hz}, 1 \mathrm{H}), 4.18(\mathrm{dd}, J=10.1,17.9 \mathrm{~Hz}, 1 \mathrm{H}), 5.31(\mathrm{dd}, J=3.7,10.1 \mathrm{~Hz}, 1 \mathrm{H}), 7.12(\mathrm{t}, J=8.6 \mathrm{~Hz}, 2 \mathrm{H})$, 7.21-7.34 (m, 5H), 7.40 (t, $J=7.6 \mathrm{~Hz}, 2 \mathrm{H}), 7.49$ (t, $J=7.4 \mathrm{~Hz}, 1 \mathrm{H}), 7.98-8.05$ (m, 4H).

The procedure for preparing 3-methyl-5-phenyl-2-propylpyrrole was followed with use of 4-(4-fluorophenyl)-1,2-diphenyl-1,4-butanedione (1.13 g, $3.4 \mathrm{mmol})$. The crude product was purified with a flash column chromatography $($ EtOAc/hexane $=1 / 10)$ to give 5-(4-fluorophenyl)-2,3-diphenylpyrrole (929 mg, 87\%) as a colorless solid: ${ }^{1} \mathrm{H}$ NMR (400 MHz, $\mathrm{CDCl}_{3}$, TMS) $\delta 6.63(\mathrm{~d}, J=2.9 \mathrm{~Hz}, 1 \mathrm{H}), 7.10(\mathrm{t}, J=8.7$ $\mathrm{Hz}, 2 \mathrm{H}), 7.19-7.42$ (m, 10H), 7.48-7.54 (m, 2H), 8.30-8.38 (br, 1H).

The general procedure of $\mathrm{N}$-Boc protection was followed with use of 5-(4-fluorophenyl)-2,3diphenylpyrrole $(630 \mathrm{mg}, 2.0 \mathrm{mmol})$. The reaction was conducted for $24 \mathrm{~h}$. The crude product was purified with a flash column chromatography (EtOAc/hexane $=1 / 10)$ to give $\mathbf{1 h}(676 \mathrm{mg}, 81 \%)$ as a colorless solid: ${ }^{1} \mathrm{H}$ NMR (400 MHz, $\mathrm{CDCl}_{3}$, TMS) $\delta 1.13(\mathrm{~s}, 9 \mathrm{H}), 6.44(\mathrm{~s}, 1 \mathrm{H}), 7.06-7.21(\mathrm{~m}, 7 \mathrm{H}), 7.31-7.37$ $(\mathrm{m}, 5 \mathrm{H}), 7.60(\mathrm{dd}, J=5.4,8.7 \mathrm{~Hz}, 2 \mathrm{H}) ;{ }^{13} \mathrm{C}\left\{{ }^{1} \mathrm{H}\right\} \mathrm{NMR}\left(100 \mathrm{MHz}, \mathrm{CDCl}_{3}\right) \delta 27.1,84.1,112.9,114.9(\mathrm{~d}, J=$ 
$22 \mathrm{~Hz}), 125.0,126.1,127.7,128.02,128.08,128.10,129.9$ (d, $J=3 \mathrm{~Hz}), 130.2$ (d, $J=8 \mathrm{~Hz}), 130.8,131.2$, 133.4, 134.1, 134.9, 149.7, 162.2 (d, $J=247 \mathrm{~Hz}$ ); IR (thin film) 1749, 1496, 1306, $1138 \mathrm{~cm}^{-1}$; Anal. Calcd for $\mathrm{C}_{27} \mathrm{H}_{24} \mathrm{NO}_{2} \mathrm{~F}: \mathrm{C}, 78.43 ; \mathrm{H}, 5.85 ; \mathrm{N}, 3.39$. Found: C, 78.31; H, 5.95; N, 3.36.

\section{$N$-(tert-Butoxycarbonyl)-5-(4-methoxyphenyl)-2,3-diphenylpyrrole (1i).}

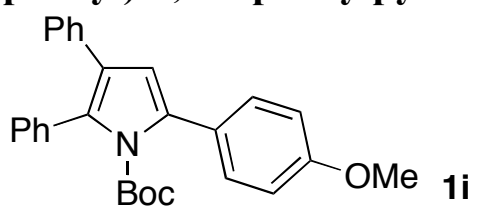

The procedure for preparing 4-(4-fluorophenyl)-1,2-diphenyl-1,4-butanedione was followed with use of 1-(4-methoxyphenyl)-3-phenyl-2-propen-1-one $(2.64 \mathrm{~g}, 11 \mathrm{mmol})$ and benzaldehyde (1.08 $\mathrm{g}, 10 \mathrm{mmol})$. The reaction was conducted for $48 \mathrm{~h}$. The crude product was purified with a flash column chromatography $($ EtOAc/hexane $=1 / 10)$ to give 4-(4-methoxyphenyl)-1,2-diphenyl-1,4-butanedione (1.36 g, 39\%) as a colorless solid: ${ }^{1} \mathrm{H}$ NMR (400 MHz, $\mathrm{CDCl}_{3}$, TMS) $\delta 3.27$ (dd, $\left.J=3.7,17.8 \mathrm{~Hz}, 1 \mathrm{H}\right), 3.86$ (s, $3 \mathrm{H}$ ), 4.17 (dd, $J$ $=10.1,17.8 \mathrm{~Hz}, 1 \mathrm{H}), 5.32(\mathrm{dd}, J=3.7,10.1 \mathrm{~Hz}, 1 \mathrm{H}), 6.91(\mathrm{~d}, J=8.9 \mathrm{~Hz}, 2 \mathrm{H}), 7.22(\mathrm{t}, J=7.2 \mathrm{~Hz}, 1 \mathrm{H}), 7.30$ $(\mathrm{t}, J=7.6 \mathrm{~Hz}, 2 \mathrm{H}), 7.34-7.43(\mathrm{~m}, 4 \mathrm{H}), 7.49(\mathrm{t}, J=7.4 \mathrm{~Hz}, 1 \mathrm{H}), 7.96(\mathrm{~d}, J=8.9 \mathrm{~Hz}, 2 \mathrm{H}), 8.01-8.06(\mathrm{~m}, 2 \mathrm{H})$.

The procedure for preparing 3-methyl-5-phenyl-2-propylpyrrole was followed with use of 4-(4-methoxyphenyl)-1,2-diphenyl-1,4-butanedione (902 $\mathrm{mg}, 2.6 \mathrm{mmol})$. The crude product was recrystallized from hexane to give 5-(4-methoxyphenyl)-2,3-diphenylpyrrole (560 g, 66\%) as a colorless crystal: ${ }^{1} \mathrm{H}$ NMR (400 MHz, $\mathrm{CDCl}_{3}$, TMS) $\delta 3.85$ (s, 3H), 6.59 (d, $\left.J=2.9 \mathrm{~Hz}, 1 \mathrm{H}\right), 6.95(\mathrm{~d}, J=8.8 \mathrm{~Hz}, 2 \mathrm{H})$, 7.18-7.34 (m, 7H), 7.38-7.42 (m, 3H), 7.48 (d, $J=8.8 \mathrm{~Hz}, 2 \mathrm{H}), 8.27-8.37$ (br, 1H).

The general procedure of $\mathrm{N}$-Boc protection was followed with use of 5-(4-methoxyphenyl)-2,3diphenylpyrrole $(540 \mathrm{mg}, 1.7 \mathrm{mmol})$. The reaction was conducted for $24 \mathrm{~h}$. The crude product was purified with a flash column chromatography (EtOAc/hexane $=1 / 10)$ to give $\mathbf{1 i}(393 \mathrm{mg}, 56 \%)$ as a colorless solid: ${ }^{1} \mathrm{H}$ NMR (400 MHz, $\mathrm{CDCl}_{3}$, TMS) $\delta 1.18(\mathrm{~s}, 9 \mathrm{H}), 3.88(\mathrm{~s}, 3 \mathrm{H}), 6.46(\mathrm{~s}, 1 \mathrm{H}), 6.98(\mathrm{~d}, J=8.7 \mathrm{~Hz}, 2 \mathrm{H})$, 7.13-7.25 (m, 5H), 7.35-7.40 (m, 5H), $7.42(\mathrm{~d}, J=8.7 \mathrm{~Hz}, 2 \mathrm{H}) ;{ }^{13} \mathrm{C}\left\{{ }^{1} \mathrm{H}\right\}$ NMR $\left(100 \mathrm{MHz}, \mathrm{CDCl}_{3}\right) \delta 27.1$, 55.3, 83.8, 112.3, 113.4, 124.8, 125.9, 126.3, 127.6, 127.99, 128.04, 128.1, 129.8, 130.7, 130.8, 133.6, 135.0, 135.2, 149.9, 159.0; IR (thin film) 1748, 1496, 1305, 1250, $1135 \mathrm{~cm}^{-1}$; Anal. Calcd for $\mathrm{C}_{28} \mathrm{H}_{27} \mathrm{NO}_{3}: \mathrm{C}, 79.03$; H, 6.40; N, 3.29. Found: C, 79.04; H, 6.45; N, 3.24.

\section{$N$-(tert-Butoxycarbonyl)-2-[4-(trifluoromethyl)phenyl]-3,5-diphenylpyrrole (1j).}

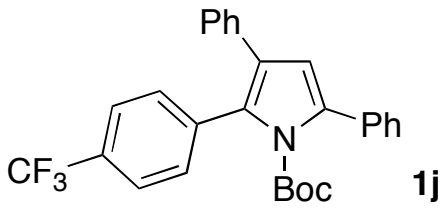

The procedure for preparing 4-(4-fluorophenyl)-1,2-diphenyl-1,4-butanedione was followed with use of 1,3-diphenyl-2-propen-1-one (11.5 g, $55 \mathrm{mmol})$ and 4-(trifluoromethyl)benzaldehyde (8.59 g, $49 \mathrm{mmol})$. The reaction was conducted for $89 \mathrm{~h}$. The crude product was purified with a flash column chromatography 
$($ EtOAc/hexane $=1 / 20)$ to give 2,4-diphenyl-1-[4-(trifluoromethyl)phenyl]-1,4-butanedione $(18.2 \mathrm{~g}, 96 \%)$ as yellow viscous oil: ${ }^{1} \mathrm{H} \mathrm{NMR}\left(400 \mathrm{MHz}, \mathrm{CDCl}_{3}, \mathrm{TMS}\right) \delta 3.34$ (dd, $\left.J=3.5,18.1 \mathrm{~Hz}, 1 \mathrm{H}\right), 4.23(\mathrm{dd}, J=10.3$, $18.1 \mathrm{~Hz}, 1 \mathrm{H}), 5.28(\mathrm{dd}, J=3.5,10.3 \mathrm{~Hz}, 1 \mathrm{H}), 7.23-7.36(\mathrm{~m}, 5 \mathrm{H}), 7.46(\mathrm{t}, J=7.7 \mathrm{~Hz}, 2 \mathrm{H}), 7.57(\mathrm{t}, J=7.4 \mathrm{~Hz}$, $1 \mathrm{H}), 7.67(\mathrm{~d}, J=8.2 \mathrm{~Hz}, 2 \mathrm{H}), 7.96-8.00(\mathrm{~m}, 2 \mathrm{H}), 8.12(\mathrm{~d}, J=8.2 \mathrm{~Hz}, 2 \mathrm{H})$.

The procedure for preparing 3-methyl-5-phenyl-2-propylpyrrole was followed with use of 2,4-diphenyl-1-[4-(trifluoromethyl)phenyl]-1,4-butanedione (18.2 g, $48 \mathrm{mmol})$. The crude product was purified with a flash column chromatography (EtOAc/hexane $=1 / 20)$ to give 2-[4-(trifluoromethyl)phenyl]3,5-diphenylpyrrole (11.5 g, 67\%) as a colorless solid: ${ }^{1} \mathrm{H}$ NMR (400 $\mathrm{MHz}, \mathrm{CDCl}_{3}$, TMS) $\delta 6.70(\mathrm{~d}, J=2.8$ $\mathrm{Hz}, 1 \mathrm{H}), 7.23-7.31(\mathrm{~m}, 2 \mathrm{H}), 7.33(\mathrm{t}, J=7.5 \mathrm{~Hz}, 2 \mathrm{H}), 7.36-7.41(\mathrm{~m}, 2 \mathrm{H}), 7.42(\mathrm{t}, J=7.8 \mathrm{~Hz}, 2 \mathrm{H}), 7.48(\mathrm{~d}, J=$ $8.2 \mathrm{~Hz}, 2 \mathrm{H}), 7.53-7.59$ (m, 4H), 8.41-8.49 (br, 1H).

The general procedure of $N$-Boc protection was followed with use of 2-[4-(trifluoromethyl)phenyl]3,5-diphenylpyrrole $(2.18 \mathrm{~g}, 6.0 \mathrm{mmol})$. The reaction was conducted for $21 \mathrm{~h}$. The crude product was purified with a flash column chromatography $($ EtOAc/hexane $=1 / 20)$ to give $\mathbf{1 j}(2.36 \mathrm{~g}, 85 \%)$ as a colorless solid: ${ }^{1} \mathrm{H}$ NMR (400 MHz, $\mathrm{CDCl}_{3}$, TMS) $\delta 1.13(\mathrm{~s}, 9 \mathrm{H}), 6.46(\mathrm{~s}, 1 \mathrm{H}), 7.10-7.23(\mathrm{~m}, 5 \mathrm{H}), 7.32-7.48(\mathrm{~m}, 7 \mathrm{H})$, $7.60(\mathrm{~d}, J=8.1 \mathrm{~Hz}, 2 \mathrm{H}) ;{ }^{13} \mathrm{C}\left\{{ }^{1} \mathrm{H}\right\} \mathrm{NMR}\left(100 \mathrm{MHz}, \mathrm{CDCl}_{3}\right) \delta 27.0,84.4,113.3,124.2(\mathrm{q}, J=272 \mathrm{~Hz}), 124.9$ $(\mathrm{q}, J=4 \mathrm{~Hz}), 126.2,126.4,127.5,128.0,128.2,128.3,128.6,129.46,129.52$ (q, $J=32 \mathrm{~Hz}), 131.1,133.7$, 134.6, 136.0, 137.2, 149.4; IR (thin film) 1750, 1325, $1136 \mathrm{~cm}^{-1}$; Anal. Calcd for $\mathrm{C}_{28} \mathrm{H}_{24} \mathrm{NO}_{2} \mathrm{~F}_{3}$ : C, 72.56; $\mathrm{H}$, 5.22; N, 3.02. Found: C, 72.57; H, 5.27; N, 3.06.

\section{$N$-(tert-Butoxycarbonyl)-2-(4-methoxyphenyl)-3,5-diphenylpyrrole (1k).}

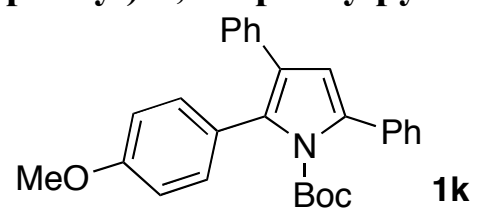

The procedure for preparing 4-(4-fluorophenyl)-1,2-diphenyl-1,4-butanedione was followed with use of 1,3-diphenyl-2-propen-1-one (2.29 g, $11.0 \mathrm{mmol})$ and 4-methoxybenzaldehyde (1.42 g, $10.4 \mathrm{mmol})$. The reaction was conducted for $72 \mathrm{~h}$. The crude product was purified with a flash column chromatography $($ EtOAc/hexane $=1 / 5)$ to give 2,4-diphenyl-1-(4-methoxyphenyl)-1,4-butanedione (2.32 g, 65\%) as yellow viscous oil: ${ }^{1} \mathrm{H}$ NMR (400 MHz, $\left.\mathrm{CDCl}_{3}, \mathrm{TMS}\right) \delta 3.27(\mathrm{dd}, J=3.8,18.0 \mathrm{~Hz}, 1 \mathrm{H}), 3.81(\mathrm{~s}, 3 \mathrm{H}), 4.20(\mathrm{dd}, J=$ 9.9, $18.0 \mathrm{~Hz}, 1 \mathrm{H}), 5.29$ (dd, $J=3.8,9.9 \mathrm{~Hz}, 1 \mathrm{H}), 6.87$ (d, J=8.9 Hz, 2H), 7.21 (t, J= 7.2 Hz, 1H), 7.30 (t, $J$ $=7.6 \mathrm{~Hz}, 2 \mathrm{H}), 7.36(\mathrm{~d}, J=7.7 \mathrm{~Hz}, 2 \mathrm{H}), 7.44(\mathrm{t}, J=7.8 \mathrm{~Hz}, 2 \mathrm{H}), 7.54(\mathrm{t}, J=7.0 \mathrm{~Hz}, 1 \mathrm{H}), 7.98(\mathrm{~d}, J=8.2 \mathrm{~Hz}$, $2 \mathrm{H}), 8.02(\mathrm{~d}, J=8.9 \mathrm{~Hz}, 2 \mathrm{H})$.

The procedure for preparing 3-methyl-5-phenyl-2-propylpyrrole was followed with use of 2,4-diphenyl-1-(4-methoxyphenyl)-1,4-butanedione (2.32 g, $6.7 \mathrm{mmol})$. The crude product was purified with a flash column chromatography (EtOAc/hexane $=1 / 10)$ to give 2-(4-methoxyphenyl)-3,5diphenylpyrrole $(1.94 \mathrm{~g}, 88 \%)$ as a colorless solid: ${ }^{1} \mathrm{H}$ NMR (400 MHz, $\mathrm{CDCl}_{3}$, TMS) $\delta 3.82(\mathrm{~s}, 3 \mathrm{H})$, 6.69 (s, 1H), 6.88 (d, $J=8.6 \mathrm{~Hz}, 2 \mathrm{H}), 7.17-7.57$ (m, 12H), 8.30-8.40 (br, 1H). 
The general procedure of $N$-Boc protection was followed with use of 2-(4-methoxyphenyl)-3,5diphenylpyrrole $(251 \mathrm{mg}, 0.77 \mathrm{mmol})$. The reaction was conducted for $24 \mathrm{~h}$. The crude product was purified with a flash column chromatography $(\mathrm{EtOAc} / \mathrm{hexane}=1 / 10)$ to give $\mathbf{1 k}(246 \mathrm{mg}, 75 \%)$ as a colorless solid: ${ }^{1} \mathrm{H}$ NMR (400 MHz, $\mathrm{CDCl}_{3}$, TMS) $\delta 1.15$ (s, 9H), $3.83(\mathrm{~s}, 3 \mathrm{H}), 6.47$ (s, 1H), 6.89 (d, $J=8.7$ $\mathrm{Hz}, 2 \mathrm{H}), 7.09-7.21(\mathrm{~m}, 5 \mathrm{H}), 7.24-7.35(\mathrm{~m}, 3 \mathrm{H}), 7.35-7.46(\mathrm{~m}, 4 \mathrm{H}) ;{ }^{13} \mathrm{C}\left\{{ }^{1} \mathrm{H}\right\} \mathrm{NMR}\left(100 \mathrm{MHz}, \mathrm{CDCl}_{3}\right) \delta$ 27.1, 55.2, 83.9, 112.5, 113.5, 124.8, 125.5, 125.9, 127.2, 127.97, 128.04, 128.06, 128.3, 131.2, 132.2, 134.0, 134.9, 135.2, 149.8, 159.2; IR (thin film) 2979, 1748, 1510, 1489, 1305, 1248, $1139 \mathrm{~cm}^{-1}$; Anal. Calcd for $\mathrm{C}_{28} \mathrm{H}_{27} \mathrm{NO}_{3}$ : C, 79.03; H, 6.40; N, 3.29. Found: C, 78.86; H, 6.66; N, 3.24.

\section{Asymmetric Hydrogenation of Pyrroles (1).}

General Procedure. Under nitrogen atmosphere, dry EtOAc $(1.0 \mathrm{ml})$ and $\operatorname{dry}^{2} \mathrm{Et}_{3} \mathrm{~N}(5.1 \mathrm{mg}, 50 \mu \mathrm{mol})$ was added to a mixture of $\mathrm{Ru}\left(\eta^{3}-\text { methallyl }\right)_{2}(\mathrm{cod})(1.6 \mathrm{mg}, 5.0 \mu \mathrm{mol})$ and $(S, S)-(R, R)-\operatorname{PhTRAP}(4.4 \mathrm{mg}, 5.5$ $\mu \mathrm{mol})$. After stirred at room temperature for $10 \mathrm{~min}$, the mixture was transferred through cannula into a pyrrole $1(0.20 \mathrm{mmol})$ in a test tube. The test tube was inserted into a nitrogen-filled stainless steel autoclave, and the autoclave was sealed immediately. Hydrogen gas was introduced into the autoclave until the pressure gauge indicated over $50 \mathrm{~atm}$, and then the pressure was carefully released to $1 \mathrm{~atm}$. This procedure was repeated twice, and finally the inside of the autoclave was pressurized with hydrogen to 50 atm. After the mixture was stirred at $80^{\circ} \mathrm{C}$ for $24 \mathrm{~h}$, the autoclave was allowed to cool to room temperature. Excess hydrogen was released carefully, and then the resulting reaction mixture was evaporated under reduced pressure. The residue was analyzed with ${ }^{1} \mathrm{H}$ NMR in order to determine its composition, and then purified with a MPLC (EtOAc/hexane) after passed through a short silica gel column.

\section{Methyl (S)-N-(tert-Butoxycarbonyl)pyrrolidine-2-carboxylate (2a) (eq 1).}

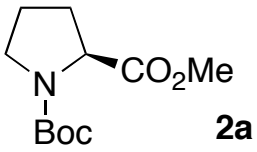

Under nitrogen atmosphere, dry $i$-PrOH $(1.0 \mathrm{ml})$ and dry $\mathrm{Et}_{3} \mathrm{~N}(5.1 \mathrm{mg}, 50 \mu \mathrm{mol})$ was added mixture of $\mathrm{Ru}\left(\eta^{3} \text {-methallyl }\right)_{2}(\mathrm{cod})(1.6 \mathrm{mg}, 5.0 \mu \mathrm{mol})$ and $(S, S)-(R, R)$-PhTRAP $(4.4 \mathrm{mg}, 5.5 \mu \mathrm{mol})$. After stirred at room temperature for $10 \mathrm{~min}$, the mixture was transferred through cannula into a mixture of pyrrole 1a in a test tube. The mixture was treated with 50 atm of hydrogen gas along the general procedure. The residue was purified with a short silica gel column $($ EtOAc/hexane $=1 / 2)$ to give the desired compound $2 \mathbf{a}(113 \mathrm{mg}$, 92\%) as colorless oil: $[\alpha]_{\mathrm{D}}{ }^{27}=-48.9(c$ 0.364, MeOH$)$, lit. ${ }^{11}[\alpha]_{\mathrm{D}}=-61.5(c 0.34, \mathrm{MeOH}) ;{ }^{1} \mathrm{H}$ NMR $(400$ $\left.\mathrm{MHz}, \mathrm{CDCl}_{3}, \mathrm{TMS}\right) \delta 1.41$ and 1.46 (a pair of s, 9H), 1.79-2.02 (m, 3H), 2.12-2.29 (m, 1H), 3.35-3.60 (m, 2H), $3.72(\mathrm{~s}, 3 \mathrm{H}), 4.22$ and 4.33 (a pair of dd, $J=4.2,8.5 \mathrm{~Hz}$ and $J=3.2,8.5 \mathrm{~Hz}, 1 \mathrm{H}) ;{ }^{13} \mathrm{C}\left\{{ }^{1} \mathrm{H}\right\} \mathrm{NMR}(100$ $\mathrm{MHz}, \mathrm{CDCl}_{3}$ ) $\delta 23.7$ and 24.3 (a pair of s), 28.3 and 28.4 (a pair of s), 30.9 and 29.9 (a pair of s), 46.3 and 46.5 (a pair of s), 51.9 and 52.1 (a pair of s), 59.1 and 58.7 (a pair of s), 79.83 and 79.78 (a pair of s), 153.8 and 154.4 (a pair of s), 173.7 and 173.5 (a pair of s). 
The enantiomeric excess of $\mathbf{2 a}$ was determined to be $79 \%$ ee by capillary GC analysis with Chirasil-DEX $\mathrm{CB}(0.25 \mathrm{~mm} \phi \times 25 \mathrm{~m}, \mathrm{df}=0.25 \mu \mathrm{m}): \mathrm{N}_{2}, 33 \mathrm{~cm} / \mathrm{sec}$ flow, at $120^{\circ} \mathrm{C},(R) t_{1}=32.8 \mathrm{~min},(S) t_{2}=34.0 \mathrm{~min}$.

\section{Methyl (-)-N-(tert-Butoxycarbonyl)-3,5-dimethylpyrrolidine-2-carboxylate $\quad$ (2b) and Methyl (-)-N-(tert-Butoxycarbonyl)-3,5-dimethyl-4,5-dihydropyrrole-2-carboxylate (3b) (Table 1, entry 1$)$.

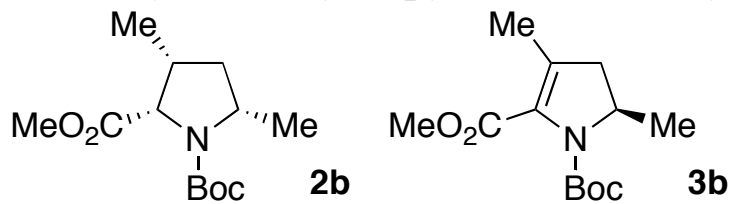

The general procedure was followed with use of pyrrole $1 \mathbf{b}(52.2 \mathrm{mg}, 0.21 \mathrm{mmol})$. The crude product was purified with a MPLC (EtOAc/hexane $=1 / 2)$ after passed through a short silica gel column $($ EtOAc/hexane $=1 / 3)$ to give $\mathbf{2 b}(27.1 \mathrm{mg}, 52 \%)$ as colorless oil and $\mathbf{3 b}(21.7 \mathrm{mg}, 42 \%)$ as colorless oil. (-)-2b: $[\alpha]_{\mathrm{D}}{ }^{27}=-9.5\left(c 0.99, \mathrm{CHCl}_{3}\right) ;{ }^{1} \mathrm{H} \mathrm{NMR}\left(400 \mathrm{MHz}, \mathrm{CDCl}_{3}, \mathrm{TMS}\right) \delta 0.97(\mathrm{~d}, J=6.9 \mathrm{~Hz}, 3 \mathrm{H})$, 1.37-1.52 (m, 13H), 2.15 (dt, $J=13.0,6.7 \mathrm{~Hz}, 1 \mathrm{H}), 2.31-2.45$ (br m, 1H), 3.72 (s, 3H), 3.69-3.88 (br m, 1H), 4.29 and 4.40 (a pair of d, $J=8.5 \mathrm{~Hz}$ and $J=8.4 \mathrm{~Hz}, 1 \mathrm{H}) ;{ }^{13} \mathrm{C}\left\{{ }^{1} \mathrm{H}\right\} \mathrm{NMR}\left(100 \mathrm{MHz}, \mathrm{CDCl}_{3}\right) \delta 14.83$ and 14.75 (a pair of s), 20.1 and 21.2 (a pair of s), 28.37 and 28.45 (a pair of s), 35.2 and 35.0 (a pair of s), 40.8 and 41.4 (a pair of s), 51.46 and 51.50 (a pair of s), 54.0 and 54.2 (a pair of s), 64.9 and 64.4 (a pair of s), 79.6 and 79.7 (a pair of s), 153.5 and 154.5 (a pair of s), 172.7; IR (neat) 2972, 1746, 1698, 1391, $1177 \mathrm{~cm}^{-1}$; Anal. Calcd for $\mathrm{C}_{13} \mathrm{H}_{23} \mathrm{NO}_{4}$ : C, 60.68; H, 9.01; N, 5.44. Found: C, 60.78; H, 8.90; N, 5.37. $\quad(-)-3 \mathbf{b}:[\alpha]_{\mathrm{D}}^{27}=$ -66.1 (c 1.01, $\left.\mathrm{CHCl}_{3}\right) ;{ }^{1} \mathrm{H}$ NMR (400 MHz, $\left.\mathrm{CDCl}_{3}, \mathrm{TMS}\right) \delta 1.25$ (d, J=6.5 Hz, 3H), 1.44 (s, $\left.9 \mathrm{H}\right), 1.88$ (s, $3 \mathrm{H}), 1.92(\mathrm{~d}, J=17.2 \mathrm{~Hz}, 1 \mathrm{H}), 2.98(\mathrm{ddq}, J=9.3,17.2,1.6 \mathrm{~Hz}, 1 \mathrm{H}), 3.81(\mathrm{~s}, 3 \mathrm{H}), 4.23-4.33(\mathrm{~m}, 1 \mathrm{H}) ;{ }^{13} \mathrm{C}$ $\left\{{ }^{1} \mathrm{H}\right\}$ NMR $\left(100 \mathrm{MHz}, \mathrm{CDCl}_{3}\right) \delta 13.7,21.8,28.2,42.7,51.6,54.7,80.6,128.0,128.6,152.9,163.5$; IR (neat) 2978, 1731, 1703, 1394, 1368, 1295, $1171 \mathrm{~cm}^{-1}$; HRMS (FAB) Calcd for $\mathrm{C}_{13} \mathrm{H}_{22} \mathrm{NO}_{4}: 256.1549$. Found: $m / z$ $=256.1531(\mathrm{M}+\mathrm{H})^{+}$.

The enantiomeric excesses of (-)-2b and (-)-3b were determined to be $11 \%$ ee and $75 \%$ ee by capillary GC analysis with Chirasil-DEX CB $(0.25 \mathrm{~mm} \phi \times 25 \mathrm{~m}, \mathrm{df}=0.25 \mu \mathrm{m}): \mathrm{N}_{2}, 33 \mathrm{~cm} / \mathrm{sec}$ flow, at $110^{\circ} \mathrm{C} . \quad 2 \mathbf{b}$ : $(+) t_{1}=62.2 \mathrm{~min},(-) t_{2}=65.0 \mathrm{~min} . \quad 3 \mathbf{b}:(-) t_{1}=87.1 \mathrm{~min},(+) t_{2}=91.2 \mathrm{~min}$.

\section{Methyl (-)- N-(tert-Butoxycarbonyl)-2,5-dimethylpyrrolidine-3-carboxylate (2c) (Table 1, entry 2).

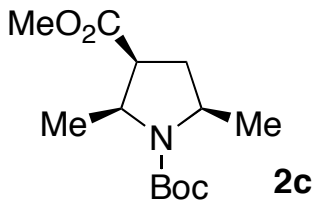

The general procedure was followed with use of pyrrole 1c $(50.9 \mathrm{mg}, 0.20 \mathrm{mmol})$. The crude product was purified with a MPLC (EtOAc/hexane $=1 / 3$ ) after passed through a short silica gel column $($ EtOAc/hexane $=1 / 3)$ to give $2 \mathrm{c}(46.8 \mathrm{mg}, 91 \%)$ as colorless oil: $[\alpha]_{\mathrm{D}}{ }^{26}=-0.94\left(c 1.06, \mathrm{CHCl}_{3}\right) ;{ }^{1} \mathrm{H} \mathrm{NMR}$ (400 MHz, $\left.\mathrm{CDCl}_{3}, \mathrm{TMS}\right) \delta 1.06(\mathrm{~d}, J=6.6 \mathrm{~Hz}, 3 \mathrm{H}), 1.34$ (br d, $\left.J=5.7 \mathrm{~Hz}, 3 \mathrm{H}\right), 1.46$ (s, 9H), 2.02 (br q, $J=$ $11.3 \mathrm{~Hz}, 1 \mathrm{H}), 2.24(\mathrm{dt}, J=13.8,7.1 \mathrm{~Hz}, 1 \mathrm{H}), 3.02(\mathrm{dt}, J=12.9,7.4 \mathrm{~Hz}), 3.70(\mathrm{~s}, 3 \mathrm{H}), 3.65-3.82(\mathrm{br} \mathrm{m}, 1 \mathrm{H})$, 
4.10-4.42 (br m, 1H); ${ }^{13} \mathrm{C}\left\{{ }^{1} \mathrm{H}\right\}$ NMR (100 MHz, $\mathrm{CDCl}_{3}$ ) $\delta 17.4$ (br s), 22.2 and 22.9 (a pair of br s), 28.5, 33.5 and 34.1 (a pair of br s), 46.0 (br s), 51.8, 52.7, 55.0, 79.3, 154.0 (br s), 171.9; IR (neat) 2975, 1742, 1688, 1389, 1303, 1257, $1176 \mathrm{~cm}^{-1}$; Anal. Calcd for $\mathrm{C}_{13} \mathrm{H}_{23} \mathrm{NO}_{4}$ : C, 60.68; H, 9.01; N, 5.44. Found: C, 60.78; H, 9.04; N, 5.48 .

The relative configuration of $\mathbf{2 c}$ was determined as follows. All peaks in the above ${ }^{1} \mathrm{H}$ NMR spectrum were assigned with the ${ }^{1} \mathrm{H}-{ }^{1} \mathrm{H}$ COSY spectrum as shown in Figure $\mathrm{S}-1$ (a). The ${ }^{1} \mathrm{H}\left\{{ }^{1} \mathrm{H}\right\}$-NOE experiment of 2c was summarized in Figure S-1 (b), indicating that the configuration is all-cis.
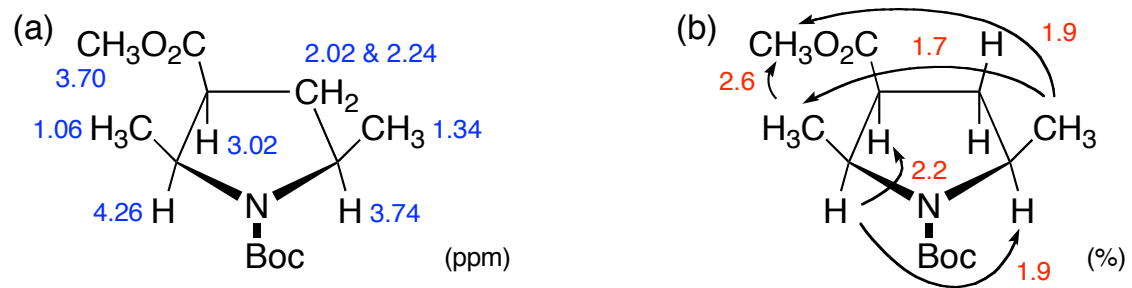

Figure S-1. Assignment of relative configuration of 2c.

The enantiomeric excess of (-)-2c was determined to be $74 \%$ ee by HPLC analysis with Chiralcel OJ-H (4.6 $\mathrm{mm} \phi \times 250 \mathrm{~mm}): 2 \%$ 2-propanol in hexane, $0.5 \mathrm{ml} / \mathrm{min}$ flow, at $35^{\circ} \mathrm{C}$, UV $230 \mathrm{~nm}$ detection, $(-) t_{1}=$ $11.4 \mathrm{~min},(+) t_{2}=12.6 \mathrm{~min}$.

\section{Methyl (-)-N-(tert-Butoxycarbonyl)-4,5-dimethylpyrrolidine-2-carboxylate (2d) (Table 1, entry 3).

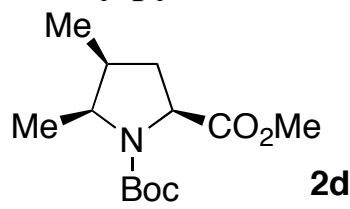

The general procedure was followed with use of pyrrole $1 \mathbf{d}(52.1 \mathrm{mg}, 0.21 \mathrm{mmol})$. The crude product was purified with a MPLC (EtOAc/hexane $=1 / 3)$ after passed through a short silica gel column $($ EtOAc/hexane $=1 / 3)$ to give $2 \mathbf{d}(45.1 \mathrm{mg}, 85 \%)$ as colorless oil: $[\alpha]_{\mathrm{D}}{ }^{27}=-38.6\left(\mathrm{c} 1.00, \mathrm{CHCl}_{3}\right) ;{ }^{1} \mathrm{H} \mathrm{NMR}$ (400 MHz, $\left.\mathrm{CDCl}_{3}, \mathrm{TMS}\right) \delta 0.98(\mathrm{~d}, J=6.3 \mathrm{~Hz}, 3 \mathrm{H}$ ), 1.13 and 1.10 (a pair of d, $J=6.7 \mathrm{~Hz}$ and $J=6.8 \mathrm{~Hz}$, $3 \mathrm{H}), 1.40$ and 1.46 (a pair of s, 9H), 1.54-1.71 (br m, 1H), 2.21-2.36 (m, 2H), $3.72(\mathrm{~s}, 3 \mathrm{H}), 3.98$ (a pair of quint, $J=6.7 \mathrm{~Hz}$ and $J=6.6 \mathrm{~Hz}, 1 \mathrm{H}$ ), 4.15 and 4.21 (a pair of dd, $J=7.1,10.1 \mathrm{~Hz}$ and $J=7.5,9.9 \mathrm{~Hz}, 1 \mathrm{H}$ ); ${ }^{13} \mathrm{C}\left\{{ }^{1} \mathrm{H}\right\}$ NMR (100 MHz, $\mathrm{CDCl}_{3}$ ) $\delta 13.8$ and 13.9 (a pair of s), 14.0 and 14.5 (a pair of s), 28.3 and 28.4 (a pair of s), 35.7 and 36.3 (a pair of s), 36.1 and 35.3 (a pair of s), 51.8 and 52.0 (a pair of s), 56.7 and 56.9 (a pair of s), 59.4 and 58.9 (a pair of s), 79.65 and 79.60 (a pair of s), 153.2 and 154.0 (a pair of s), 174.0 and 173.7 (a pair of s); IR (neat) 2975, 1755, 1699, 1391, 1256, 1176, $1127 \mathrm{~cm}^{-1}$; Anal. Calcd for $\mathrm{C}_{13} \mathrm{H}_{23} \mathrm{NO}_{4}: \mathrm{C}_{\text {, }}$ $60.68 ; \mathrm{H}, 9.01 ; \mathrm{N}, 5.44$. Found: C, 60.64; H, 8.95; N, 5.42 .

The relative configuration of $\mathbf{2 d}$ was determined as follows. All peaks in the above ${ }^{1} \mathrm{H}$ NMR spectrum were assigned with the ${ }^{1} \mathrm{H}-{ }^{1} \mathrm{H}$ COSY spectrum as shown in Figure S-2 (a). The ${ }^{1} \mathrm{H}\left\{{ }^{1} \mathrm{H}\right\}-\mathrm{NOE}$ experiment of 2d was summarized in Figure S-2 (b), indicating that the configuration is all-cis. 

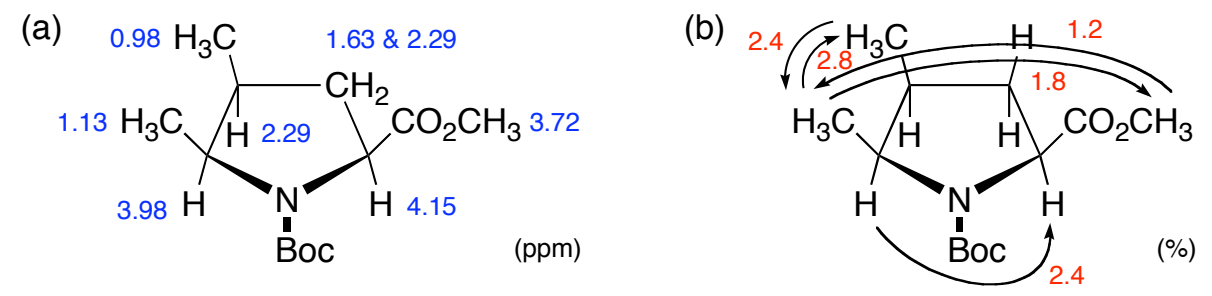

Figure S-2. Assignment of relative configuration of $\mathbf{2 d}$.

The enantiomeric excess of (-)-2d was determined to be $96 \%$ ee by capillary GC analysis with Chirasil-DEX CB $(0.25 \mathrm{~mm} \phi \times 25 \mathrm{~m}, \mathrm{df}=0.25 \mu \mathrm{m}): \mathrm{N}_{2}, 33 \mathrm{~cm} / \mathrm{sec}$ flow, at $130^{\circ} \mathrm{C},(+) t_{1}=29.1 \mathrm{~min},(-) t_{2}$ $=31.0 \mathrm{~min}$.

\section{Methyl (S)-N-(tert-Butoxycarbonyl)-2,3,4,5,6,7-hexahydroindole-2-carboxylate (3e) (Table 1, entry 4).}

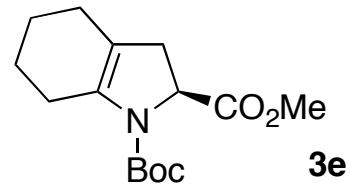

The general procedure was followed with use of pyrrole $1 \mathrm{e}(56.0 \mathrm{mg}, 0.20 \mathrm{mmol})$. The crude product was purified with a MPLC (EtOAc/hexane $=1 / 3)$ after passed through a short silica gel column $($ EtOAc/hexane $=1 / 3)$ to give $\mathbf{3 e}(39.2 \mathrm{mg}, 70 \%)$ as a colorless solid and $\mathbf{2 e}(4.6 \mathrm{mg}, 8 \%)$. (-)-3e: $[\alpha]_{\mathrm{D}}{ }^{29}$ $=-94.5\left(c 1.02, \mathrm{CHCl}_{3}\right) ;{ }^{1} \mathrm{H}$ NMR $\left(400 \mathrm{MHz}, \mathrm{C}_{6} \mathrm{D}_{6}\right) \delta 1.27-1.47(\mathrm{~m}, 4 \mathrm{H}), 1.41(\mathrm{~s}, 9 \mathrm{H}), 1.57-1.74(\mathrm{~m}, 2 \mathrm{H})$, 2.21 (br d, $J=15.5 \mathrm{~Hz}, 1 \mathrm{H}), 2.42$ (br t, $J=13.7 \mathrm{~Hz}, 1 \mathrm{H}), 2.60-3.00$ (br, 2H), 3.37 (s, 3H), 4.30-4.95 (br, $1 \mathrm{H}) ;{ }^{13} \mathrm{C}\left\{{ }^{1} \mathrm{H}\right\}$ NMR (100 MHz, $\left.\mathrm{C}_{6} \mathrm{D}_{6}\right) \delta 22.5,23.0$ (br s), 24.7, 25.1 (br s), 28.4, 36.4 (br s), 51.5, 59.4, 79.7 (br s), 112.7 (br s), 137.0 (br s), 151.6 (br s), 172.7; IR (thin film) 2933, 1759, 1715, 1686, 1402, $1150 \mathrm{~cm}^{-1}$; Anal. Calcd for $\mathrm{C}_{15} \mathrm{H}_{23} \mathrm{NO}_{4}$ : C, 64.03; H, 8.24; N, 4.98. Found: C, 63.93; H, 8.18; N, 4.93.

The enantiomeric excess of (-)-3e was determined to be $95 \%$ ee by capillary GC analysis with Chirasil-DEX CB $(0.25 \mathrm{~mm} \phi \times 25 \mathrm{~m}, \mathrm{df}=0.25 \mu \mathrm{m}): \mathrm{N}_{2}, 33 \mathrm{~cm} / \mathrm{sec}$ flow, at $160^{\circ} \mathrm{C},(S) t_{1}=33.3 \mathrm{~min},(R) t_{2}$ $=36.0 \mathrm{~min}$. The diastereomeric and enantiomeric excesses of $2 \mathrm{e}$ were determined to be $89 \%$ de, $91 \%$ ee (major), and 44\% ee (minor) by capillary GC analysis with Chirasil-DEX CB $(0.25 \mathrm{~mm} \phi \times 25 \mathrm{~m}, \mathrm{df}=0.25$ $\mu \mathrm{m}): \mathrm{N}_{2}, 33 \mathrm{~cm} / \mathrm{sec}$ flow, at $150^{\circ} \mathrm{C}$. Major diastereomer: $(2 R, 3 \mathrm{a} R, 7 \mathrm{a} R) t_{1}=47.4 \mathrm{~min},(2 S, 3 \mathrm{a} S, 7 \mathrm{a} S) t_{2}=$ $49.7 \mathrm{~min}$. Minor diastereomer: $t_{1}=46.1 \mathrm{~min}, t_{2}=53.2 \mathrm{~min}$.

The stereochemistry was assigned by the specific rotation of methyl $N$-(tert-butoxycarbonyl)octahydroindole-2-carboxylate $\mathbf{2} \mathbf{e}^{12}$ derived from the hydrogenation product (-)-3e.

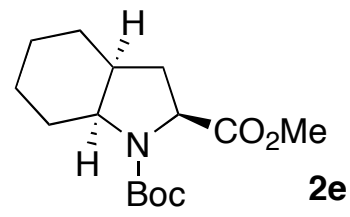

Under nitrogen atmosphere, a mixture of (-)-3e (95\% ee, $45.4 \mathrm{mg}, 0.16 \mathrm{mmol})$ and $5 \%$ palladium on carbon (34 mg) was dissolved in dry $\mathrm{MeOH}$ in a test tube. The test tube was inserted into a nitrogen-filled 
stainless steel autoclave, and the autoclave was sealed immediately. Hydrogen gas was introduced into the autoclave until the pressure gauge indicated over $50 \mathrm{~atm}$, and then the pressure was carefully released to 1 atm. The inside of the autoclave was pressurized with hydrogen to $50 \mathrm{~atm}$. The reaction mixture was vigorously stirred at room temperature for $24 \mathrm{~h}$. The resulting suspension was filtered through a Celite pad and evaporated under reduced pressure. The residue was purified with a flash column chromatography $($ EtOAc/hexane $=1 / 4)$ to give $2 \mathrm{e}(38.2 \mathrm{mg}, 84 \%)$ as colorless oil: $[\alpha]_{\mathrm{D}}^{25}=-36.8\left(c 1.02, \mathrm{CHCl}_{3}\right)$, lit. $^{12}[\alpha]_{\mathrm{D}}{ }^{22}$ $=-32.7\left(c 1.21, \mathrm{CHCl}_{3}\right) ;{ }^{1} \mathrm{H}$ NMR $\left(400 \mathrm{MHz}, \mathrm{CDCl}_{3}, \mathrm{TMS}\right) \delta 1.08-1.52(\mathrm{~m}, 4 \mathrm{H}), 1.40$ and 1.45 (a pair of s, $9 \mathrm{H}), 1.54-1.75(\mathrm{~m}, 3 \mathrm{H}), 1.91-2.18(\mathrm{~m}, 3 \mathrm{H}), 2.23-2.37(\mathrm{~m}, 1 \mathrm{H}), 3.67-3.87(\mathrm{~m}, 1 \mathrm{H}), 3.73(\mathrm{~s}, 3 \mathrm{H}), 4.19$ and $4.26(\mathrm{dd}, J=7.9,9.7 \mathrm{~Hz}$ and $J=7.7,10.1 \mathrm{~Hz}, 1 \mathrm{H}) ;{ }^{13} \mathrm{C}\left\{{ }^{1} \mathrm{H}\right\} \mathrm{NMR}\left(100 \mathrm{MHz}, \mathrm{CDCl}_{3}\right) \delta 20.6$ and 20.5 (a pair of s), 23.7 and 23.8 (a pair of s), 25.8 and 25.9 (a pair of s), 27.5 and 27.9 (a pair of s), 28.3 and 28.5 (a pair of s), 32.5 and 31.7 (a pair of s), 36.4 and 37.1 (a pair of s), 51.9 and 52.1 (a pair of s), 57.1 and 57.4 (a pair of s), 59.3 and 58.8 (a pair of s), 79.64 and 79.55 (a pair of s), 153.3 and 154.0 (a pair of s), 174.1 and 173.9 (a pair of s).

The specific rotation indicated the absolute configuration of (-)-3e to be $S$.

\section{(-)-N-(tert-Butoxycarbonyl)-3-methyl-5-phenyl-2-propylpyrrolidine (2f) (Table 1, entry 5).

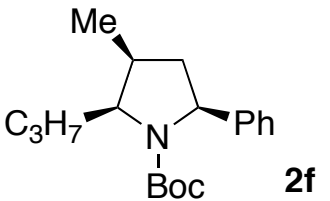

The general procedure was followed with use of pyrrole $\mathbf{1 f}(62 \mathrm{mg}, 0.21 \mathrm{mmol})$. The crude product was purified with a short silica gel column $($ EtOAc/hexane $=1 / 10)$ to give $\mathbf{2 f}(60 \mathrm{mg}, 96 \%)$ as colorless oil: $[\alpha]_{\mathrm{D}}{ }^{25}$ $=-43.0\left(c\right.$ 0.97, $\left.\mathrm{CHCl}_{3}\right) ;{ }^{1} \mathrm{H}$ NMR $\left(400 \mathrm{MHz}, \mathrm{CDCl}_{3}, \mathrm{TMS}\right) \delta$ 0.92-1.66 (m, 20H), 2.21-2.41 (m, 2H), 3.88-4.09 (br, 1H), 4.50-4.95 (br, 1H), 7.15-7.22 (m, 3H), $7.28(\mathrm{t}, J=7.5 \mathrm{~Hz}, 2 \mathrm{H}) ;{ }^{13} \mathrm{C}\left\{{ }^{1} \mathrm{H}\right\}$ NMR $(100$ $\mathrm{MHz}, \mathrm{CDCl}_{3}$ ) $\delta 14.2,14.6,20.3$ (br s), 28.1 (br s), 33.5 (br s), 36.4 (br s), 42.7 and 42.0 (a pair of br s), 61.2 (br s), 62.6 and 62.2 (a pair of br s), 78.9 (br s), 125.4 (br s), 126.2, 128.1 (br s), 145.5 and 144.9 (a pair of br s), 155.3 (br s); IR (neat) 2959, 1697, 1384, $1169 \mathrm{~cm}^{-1}$; Anal. Calcd for $\mathrm{C}_{19} \mathrm{H}_{29} \mathrm{NO}_{2}: \mathrm{C}, 75.21 ; \mathrm{H}, 9.63 ; \mathrm{N}$, 4.62. Found: C, 75.29; H, 9.70; N, 4.58 .

The enantiomeric excess of (-)-2f was determined to be $93 \%$ ee by HPLC analysis with Chiralpak AD-H (4.6 $\mathrm{mm} \phi \times 250 \mathrm{~mm}): 4 \%$ 2-propanol in hexane, $0.5 \mathrm{ml} / \mathrm{min}$ flow, at $35^{\circ} \mathrm{C}$, UV $220 \mathrm{~nm}$ detection, $(-) t_{1}=$ $7.7 \mathrm{~min},(+) t_{2}=8.8 \mathrm{~min}$.

\section{(-)-N-(tert-Butoxycarbonyl)-2,3,5-triphenyl-4,5-dihydropyrrole (3g) (Table 1, entry 6).}

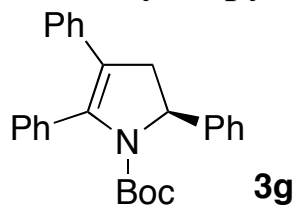


The general procedure was followed with use of pyrrole $1 \mathrm{~g}(80.1 \mathrm{mg}, 0.20 \mathrm{mmol})$. The crude product was purified with a short silica gel column $($ EtOAc/hexane $=1 / 3)$ to give $\mathbf{3 g}(80.6 \mathrm{mg},>99 \%)$ as a colorless solid: $[\alpha]_{\mathrm{D}}{ }^{28}=-300.8\left(c 0.99, \mathrm{CHCl}_{3}\right) ;{ }^{1} \mathrm{H}$ NMR $\left(400 \mathrm{MHz}, \mathrm{CDCl}_{3}, \mathrm{TMS}\right) \delta 1.08(\mathrm{~s}, 9 \mathrm{H}), 2.71$ (dd, $J=2.4$, $15.6 \mathrm{~Hz}, 1 \mathrm{H}), 3.89$ (dd, $J=10.5,15.6 \mathrm{~Hz}, 1 \mathrm{H}), 5.43$ (dd, $J=2.4,10.5 \mathrm{~Hz}, 1 \mathrm{H}), 6.91-6.95$ (m, 2H), 7.02-7.12 $(\mathrm{m}, 3 \mathrm{H}), 7.26(\mathrm{t}, J=7.3 \mathrm{~Hz}, 1 \mathrm{H}), 7.30-7.38(\mathrm{~m}, 7 \mathrm{H}), 7.46(\mathrm{~d}, J=7.5 \mathrm{~Hz}, 2 \mathrm{H}) ;{ }^{13} \mathrm{C}\left\{{ }^{1} \mathrm{H}\right\} \mathrm{NMR}(100 \mathrm{MHz}$, $\left.\mathrm{CDCl}_{3}\right) \delta 27.8,41.8,61.5,80.2,119.0,125.5,126.0,127.1,127.2,127.8,127.9,128.2,128.7,129.0,134.6$, 136.0, 137.8, 144.3, 152.7; IR (thin film) 2977, 1692, 1387, 1366, $1167 \mathrm{~cm}^{-1}$; HRMS (FAB) Calcd for $\mathrm{C}_{27} \mathrm{H}_{27} \mathrm{NO}_{2}$ : 397.2042. Found: $m / z=397.2031 \mathrm{M}^{+}$.

The enantiomeric excess of (S)-3g was determined to be $99.7 \%$ ee by HPLC analysis with Chiralpak $\mathrm{AD}-\mathrm{H}(4.6 \mathrm{~mm} \phi \times 250 \mathrm{~mm}): 2 \%$ 2-propanol in hexane, $0.5 \mathrm{ml} / \mathrm{min}$ flow, at $35^{\circ} \mathrm{C}, \mathrm{UV} 254 \mathrm{~nm}$ detection, $(+)$ $t_{1}=11.0 \mathrm{~min},(-) t_{2}=17.2 \mathrm{~min}$.

\section{(-)- $N$-(tert-Butoxycarbonyl)-5-(4-fluorophenyl)-2,3-diphenyl-4,5-dihydropyrrole (3h) (Table 1 entry 7).}

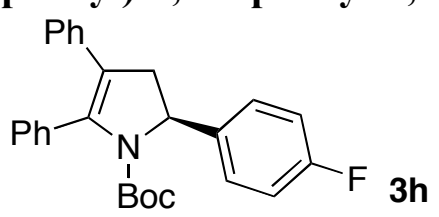

The general procedure was followed with use of pyrrole $1 \mathbf{h}(82.4 \mathrm{mg}, 0.20 \mathrm{mmol})$. The crude product was purified with a short silica gel column $(\mathrm{EtOAc} / \mathrm{hexane}=1 / 3)$ to give $\mathbf{3 h}(82.0 \mathrm{mg}, 99 \%)$ as a colorless solid: $[\alpha]_{\mathrm{D}}{ }^{25}=-207.5\left(c 0.99, \mathrm{CHCl}_{3}\right) ;{ }^{1} \mathrm{H}$ NMR $\left(400 \mathrm{MHz}, \mathrm{CDCl}_{3}, \mathrm{TMS}\right) \delta 1.08(\mathrm{~s}, 9 \mathrm{H}), 2.67$ (dd, $J=2.3$, $15.7 \mathrm{~Hz}, 1 \mathrm{H}), 3.87$ (dd, $J=10.5,15.7 \mathrm{~Hz}, 1 \mathrm{H}), 5.41$ (dd, $J=2.3,10.5 \mathrm{~Hz}, 1 \mathrm{H}), 6.91-6.95$ (m, 2H), 7.01-7.12 $(\mathrm{m}, 5 \mathrm{H}), 7.28-7.34(\mathrm{~m}, 5 \mathrm{H}), 7.46(\mathrm{dd}, J=5.4,8.5 \mathrm{~Hz}, 2 \mathrm{H}) ;{ }^{13} \mathrm{C}\left\{{ }^{1} \mathrm{H}\right\} \mathrm{NMR}\left(100 \mathrm{MHz}, \mathrm{CDCl}_{3}\right) \delta 27.7,41.7$, $60.8,80.3,115.4(\mathrm{~d}, J=21 \mathrm{~Hz}), 118.9,126.1,127.0,127.1(\mathrm{~d}, J=8 \mathrm{~Hz}), 127.8,127.9,128.2,128.9,134.4$, 135.8, 137.6, 140.1 (d, $J=3 \mathrm{~Hz}), 152.7,162.0(\mathrm{~d}, J=245 \mathrm{~Hz}$ ); IR (thin film) 2975, 1509, 1692, 1388, 1157 $\mathrm{cm}^{-1}$; Anal. Calcd for $\mathrm{C}_{27} \mathrm{H}_{26} \mathrm{NO}_{2} \mathrm{~F}$ : C, 78.05; H, 6.31; N, 3.37. Found: C, 78.14; H, 6.40; N, 3.37.

The enantiomeric excess of (S)-3h was determined to be $99.3 \%$ ee by HPLC analysis with Chiralpak $\mathrm{AD}-\mathrm{H}(4.6 \mathrm{~mm} \phi \times 250 \mathrm{~mm}): 4 \%$ 2-propanol in hexane, $0.5 \mathrm{ml} / \mathrm{min}$ flow, at $35^{\circ} \mathrm{C}, \mathrm{UV} 306 \mathrm{~nm}$ detection, $(+)$ $t_{1}=8.9 \mathrm{~min},(-) t_{2}=13.8 \mathrm{~min}$.

\section{(-)-N-(tert-Butoxycarbonyl)-5-(4-methoxyphenyl)-2,3-diphenyl-4,5-dihydropyrrole (3i) (Table 1 entry} 8).

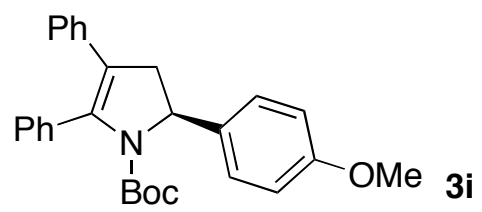

The general procedure was followed with use of pyrrole $1 \mathbf{i}(86.2 \mathrm{mg}, 0.2026 \mathrm{mmol})$. The crude product was purified with a short silica gel column $($ EtOAc/hexane $=1 / 3)$ to give $3 \mathbf{i}(82.9 \mathrm{mg}, 96 \%)$ as a colorless solid: $[\alpha]_{\mathrm{D}}{ }^{26}=-230.4\left(c 1.01, \mathrm{CHCl}_{3}\right) ;{ }^{1} \mathrm{H} \mathrm{NMR}\left(400 \mathrm{MHz}, \mathrm{CDCl}_{3}, \mathrm{TMS}\right) \delta 1.08(\mathrm{~s}, 9 \mathrm{H}), 2.68(\mathrm{dd}, J=2.2$, 
$15.6 \mathrm{~Hz}, 1 \mathrm{H}), 3.78(\mathrm{~s}, 3 \mathrm{H}), 3.85(\mathrm{dd}, J=10.3,15.6 \mathrm{~Hz}, 1 \mathrm{H}), 5.38(\mathrm{dd}, J=2.2,10.3 \mathrm{~Hz}, 1 \mathrm{H}), 6.89(\mathrm{~d}, J=8.6$ $\mathrm{Hz}, 2 \mathrm{H}), 6.91-6.95(\mathrm{~m}, 2 \mathrm{H}), 7.01-7.11(\mathrm{~m}, 3 \mathrm{H}), 7.27-7.33(\mathrm{~m}, 5 \mathrm{H}), 7.39(\mathrm{~d}, J=8.6 \mathrm{~Hz}, 2 \mathrm{H}) ;{ }^{13} \mathrm{C}\left\{{ }^{1} \mathrm{H}\right\} \mathrm{NMR}$ $\left(100 \mathrm{MHz}, \mathrm{CDCl}_{3}\right) \delta$ 27.8, 41.7, 55.2, 61.0, 80.1, 114.0, 119.1, 125.9, 126.7, 127.0, 127.7, 127.8, 128.1, 128.9, 134.6, 136.0, 136.5, 137.6, 152.7, 158.7; IR (thin film) 2974, 1691, 1513, 1388, 1248, $1173 \mathrm{~cm}^{-1}$; Anal. Calcd for $\mathrm{C}_{28} \mathrm{H}_{29} \mathrm{NO}_{3}$ : C, 78.66; H, 6.84; N, 3.28. Found: C, 78.76; H, 6.89; N, 3.30.

The enantiomeric excess of $(S)-3 \mathbf{i}$ was determined to be $98 \%$ ee by HPLC analysis with Chiralpak AD-H (4.6 $\mathrm{mm} \phi \times 250 \mathrm{~mm}): 2 \%$ 2-propanol in hexane, $0.5 \mathrm{ml} / \mathrm{min}$ flow, at $35^{\circ} \mathrm{C}, \mathrm{UV} 305 \mathrm{~nm}$ detection, $(+) t_{1}=$ $11.7 \mathrm{~min},(-) t_{2}=18.0 \mathrm{~min}$.

\section{(-)-N-(tert-Butoxycarbonyl)-2-[4-(trifluoromethyl)phenyl]-3,5-diphenyl-4,5-dihydropyrrole (3j) (Table} 1 entry 9).

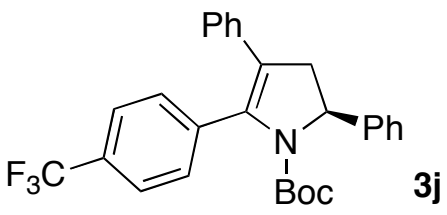

The general procedure was followed with use of pyrrole $\mathbf{1 j}(92.7 \mathrm{mg}, 0.20 \mathrm{mmol})$. The crude product was purified with a short silica gel column (EtOAc/hexane $=1 / 5)$ to give $\mathbf{3 j}(93.4 \mathrm{mg},>99 \%)$ as a colorless solid: $[\alpha]_{\mathrm{D}}{ }^{26}=-232.5\left(c 1.00, \mathrm{CHCl}_{3}\right) ;{ }^{1} \mathrm{H} \mathrm{NMR}\left(400 \mathrm{MHz}, \mathrm{CDCl}_{3}, \mathrm{TMS}\right) \delta 1.09(\mathrm{~s}, 9 \mathrm{H}), 2.75(\mathrm{dd}, J=2.4$, $15.9 \mathrm{~Hz}, 1 \mathrm{H}), 3.89$ (dd, $J=10.5,15.9 \mathrm{~Hz}, 1 \mathrm{H}), 5.43$ (dd, $J=2.4,10.5 \mathrm{~Hz}, 1 \mathrm{H}), 6.90-6.98(\mathrm{~m}, 2 \mathrm{H}), 7.06-7.15$ $(\mathrm{m}, 3 \mathrm{H}), 7.24-7.31(\mathrm{~m}, 1 \mathrm{H}), 7.34(\mathrm{t}, J=7.5 \mathrm{~Hz}, 2 \mathrm{H}), 7.41-7.47(\mathrm{~m}, 4 \mathrm{H}), 7.58(\mathrm{~d}, J=8.1 \mathrm{~Hz}, 2 \mathrm{H}) ;{ }^{13} \mathrm{C}\left\{{ }^{1} \mathrm{H}\right\}$ $\operatorname{NMR}\left(100 \mathrm{MHz}, \mathrm{CDCl}_{3}\right) \delta 27.8,42.1,61.6,80.7,121.0,124.1$ (q, $\left.J=272 \mathrm{~Hz}\right), 125.0$ (q, $\left.J=4 \mathrm{~Hz}\right), 125.4$, 126.6, 127.2, 127.4, 128.1, 128.8, 129.4, 129.7 (q, $J=32 \mathrm{~Hz}$ ), 135.3, 136.1, 138.3, 144.0, 152.7; IR (thin

film) 2978, 1698, 1378, 1327, $1165 \mathrm{~cm}^{-1}$; Anal. Calcd for $\mathrm{C}_{28} \mathrm{H}_{26} \mathrm{NO}_{2} \mathrm{~F}_{3}: \mathrm{C}, 72.24 ; \mathrm{H}, 5.63 ; \mathrm{N}, 3.01$. Found: C, 72.13; H, 5.69; N, 3.01 .

The enantiomeric excess of $(S)-3 \mathbf{j}$ was determined to be $99.6 \%$ ee by HPLC analysis with Chiralpak AD-H (4.6 $\mathrm{mm} \phi \times 250 \mathrm{~mm}$ ): 4\% 2-propanol in hexane, $0.5 \mathrm{ml} / \mathrm{min}$ flow, at $35^{\circ} \mathrm{C}$, UV $306 \mathrm{~nm}$ detection, $(+) t_{1}=$ $8.3 \mathrm{~min},(-) t_{2}=9.3 \mathrm{~min}$.

\section{(-)-N-(tert-Butoxycarbonyl)-2-(4-methoxyphenyl)-3,5-diphenyl-4,5-dihydropyrrole (3k) (Table 1 entry} 10).

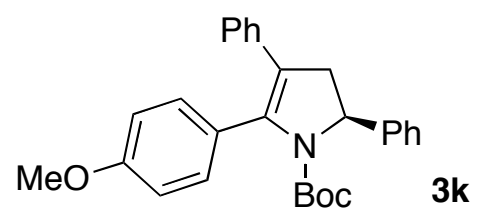

The general procedure was followed with use of pyrrole $1 \mathbf{k}(84.8 \mathrm{mg}, 0.20 \mathrm{mmol})$. The crude product was purified with a short silica gel column (EtOAc/hexane $=1 / 5)$ to give 3k $(82.3 \mathrm{mg}, 97 \%)$ as a colorless solid: $[\alpha]_{\mathrm{D}}{ }^{25}=-238.0\left(c 0.99, \mathrm{CHCl}_{3}\right) ;{ }^{1} \mathrm{H} \mathrm{NMR}\left(400 \mathrm{MHz}, \mathrm{CDCl}_{3}, \mathrm{TMS}\right) \delta 1.12(\mathrm{~s}, 9 \mathrm{H}), 2.69(\mathrm{dd}, J=2.4$, $15.5 \mathrm{~Hz}, 1 \mathrm{H}), 3.83(\mathrm{~s}, 3 \mathrm{H}), 3.85(\mathrm{dd}, J=10.5,15.5 \mathrm{~Hz}, 1 \mathrm{H}), 5.40(\mathrm{dd}, J=2.4,10.5 \mathrm{~Hz}, 1 \mathrm{H}), 6.87(\mathrm{~d}, J=8.7$ 
$\mathrm{Hz}, 2 \mathrm{H}), 6.93-6.97(\mathrm{~m}, 2 \mathrm{H}), 7.04(\mathrm{t}, J=7.2 \mathrm{~Hz}, 1 \mathrm{H}), 7.10(\mathrm{t}, J=7.3 \mathrm{~Hz}, 2 \mathrm{H}), 7.23-7.28(\mathrm{~m}, 3 \mathrm{H}), 7.35(\mathrm{t}, J=$ $7.6 \mathrm{~Hz}, 2 \mathrm{H}), 7.44(\mathrm{~d}, J=7.3 \mathrm{~Hz}, 2 \mathrm{H}) ;{ }^{13} \mathrm{C}\left\{{ }^{1} \mathrm{H}\right\} \mathrm{NMR}\left(100 \mathrm{MHz}, \mathrm{CDCl}_{3}\right) \delta$ 27.9, 41.7, 55.2, 61.4, 80.1, 113.6, $118.4,125.5,125.9,126.8,127.0,127.1,127.9,128.6,130.2,136.2,137.6,144.4,152.7,159.2$; IR (thin film) 2974, 1690, 1387, 1247, $1173 \mathrm{~cm}^{-1}$; HRMS (FAB) Calcd for $\mathrm{C}_{28} \mathrm{H}_{29} \mathrm{NO}_{3}: 427.2147$. Found: $m / z=$ 427.2181 $\mathrm{M}^{+}$.

The enantiomeric excess of $(S)$-3k was determined to be $99.2 \%$ ee by HPLC analysis with Chiralpak AD-H (4.6 $\mathrm{mm} \phi \times 250 \mathrm{~mm}$ ): 4\% 2-propanol in hexane, $0.5 \mathrm{ml} / \mathrm{min}$ flow, at $35^{\circ} \mathrm{C}, \mathrm{UV} 305 \mathrm{~nm}$ detection, $(+)$ $t_{1}=12.7 \mathrm{~min},(-) t_{2}=16.3 \mathrm{~min}$.

\section{Evaluation of Various Chiral Ligands on the Asymmetric Hydrogenation of 1a. (note 15)}

Asymmetric induction of each chiral ligand was evaluated by following the procedure for eq 1 . Chiral ligands $(5.5 \mathrm{mmol})$ were used in place of $(S, S)-(R, R)$-PhTRAP. The result of the ligand screening was summarized in Table S-1.

Table S-1. Screening of Chiral Ligands.

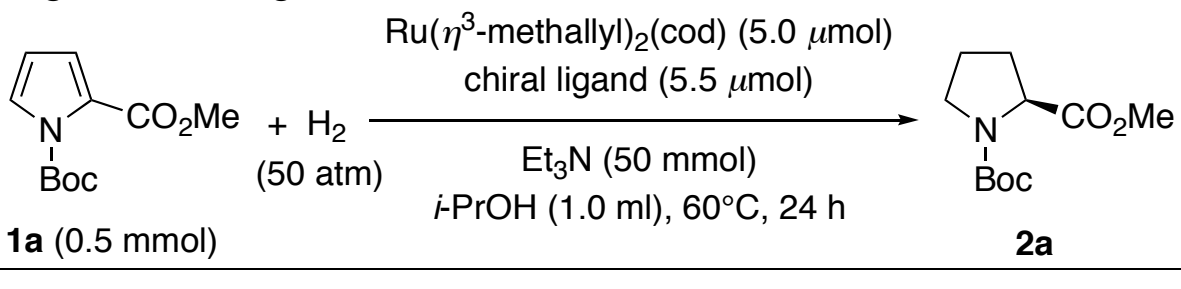

\begin{tabular}{|c|c|c|c|c|c|c|c|}
\hline entry & ligand & convn, $\%$ & ee, $\%$ & entry & ligand & convn, $\%$ & ee, $\%$ \\
\hline 1 & $(S, S)-(R, R)$-PhTRAP & 100 & $79(S)$ & 9 & $\mathbf{L 2}$ & 100 & $2(R)$ \\
\hline 2 & $(2 S, 3 S)-\mathrm{DIOP}$ & 100 & $1(S)$ & 10 & $\mathbf{L 3}$ & 35 & $3(R)$ \\
\hline 3 & $(R)-(S)$-BPPFA & 100 & 0 & 11 & L4 & 100 & $2(R)$ \\
\hline 4 & $(R)$-PHANEPHOS & 100 & 0 & 12 & $\mathbf{L 5}$ & 7 & $3(R)$ \\
\hline 5 & $(2 S, 3 S)$-CHIRAPHOS & 100 & 0 & 13 & L6 & 0 & - \\
\hline 6 & $(R)$-BINAP & 57 & $1(S)$ & 14 & L7 & 7 & $1(S)$ \\
\hline 7 & $(R, R)$-Me-DuPHOS & 48 & $39(S)$ & 15 & L8 & 34 & $2(S)$ \\
\hline 8 & $\mathbf{L 1}$ & 5 & $3(S)$ & & & & \\
\hline
\end{tabular}




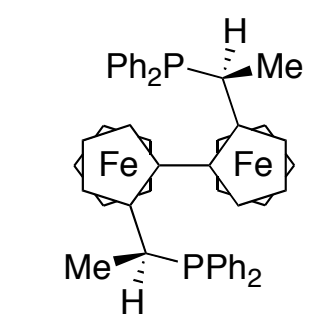

$(S, S)-(R, R)$-PhTRAP

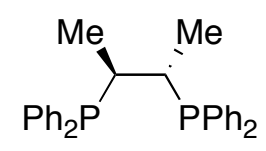

(2S,3S)-CHIRAPHOS

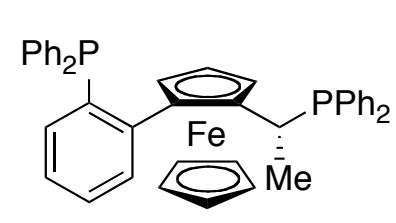

L5

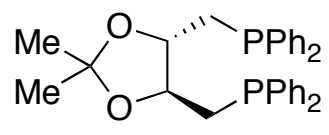

(2S,3S)-DIOP<smiles>c1ccc(-c2ccc3ccccc3c2-c2c(P(c3ccccc3)c3ccccc3)ccc3ccccc23)cc1</smiles>

(R)-BINAP

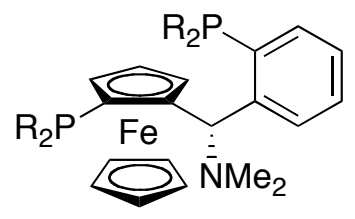

L6: $\mathrm{R}=\mathrm{Ph}$

L7: $\mathrm{R}=c-\mathrm{C}_{6} \mathrm{H}_{11}$

L8: $\mathrm{R}=3,5-\mathrm{Me}_{2}-4-\mathrm{MeOC}_{6} \mathrm{H}_{2}$

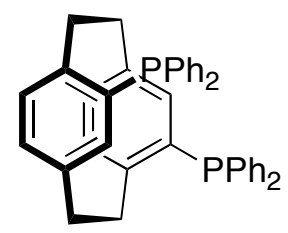

(R)-PHANEPHOS

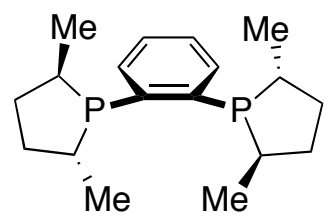

$(R, R)$-Me-DuPHOS

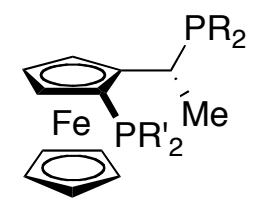

L1: $\mathrm{R}=\mathrm{R}^{\prime}=c-\mathrm{C}_{6} \mathrm{H}_{11}$

L2: $\mathrm{R}=c-\mathrm{C}_{6} \mathrm{H}_{11}, \mathrm{R}^{\prime}=\mathrm{Ph}$

L3: $\mathrm{R}=t-\mathrm{Bu}, \mathrm{R}^{\prime}=\mathrm{Ph}$

L4: $\mathrm{R}=3,5-\mathrm{Me}_{2} \mathrm{C}_{6} \mathrm{H}_{3^{-}}, \mathrm{R}^{\prime}=\mathrm{Ph}$

\section{Estimation of the Enantioselelctivity in the Transformation of $1 \mathrm{~b}$ into $3 \mathrm{~b}$. (note 15)}

The net enantioselectivity was estimated as follows. Compositions of $\mathbf{1 b}, \mathbf{2} \mathbf{b}$, and $\mathbf{3} \mathbf{b}$ in the reaction mixtures at 6 and $24 \mathrm{~h}$ were calculated from eq 2 and summarized in Table S-2. The stereoselectivity in the first transformation of $\mathbf{1 b}$ into $\mathbf{3 b}$ would equal $\{(a+c)-(b+d)\} /\{(a+c)+(b+d)\} \times 100=41 \%$ ee $(-)$ (average) when (-)-3b was presumed to give (-)-2b through the second hydrogenation (path A, Scheme S-1). Alternatively, it would be $\{(a+d)-(b+c)\} /\{(a+d)+(b+c)\} \times 100=28 \%$ ee $(-)$ (average) when $(-)-2 \mathbf{b}$ was obtained from (+)-3b (path B). In the former case, the enantiomeric excess of $\mathbf{2 b}$ must be close to $41 \%$ ee $(-)$ as the fully hydrogenated product increased. The ee value of $\mathbf{2} \mathbf{b}$, however, got away from $41 \%$ ee $(-)$ over time according to our observation. Consequently, the formation of $\mathbf{2} \mathbf{b}$ from $\mathbf{3 b}$ proceeded through path B. The virtual stereoselectivity of the first step was estimated to be $28 \%$ ee (-).

Table S-2. Compositions of each compound.

\begin{tabular}{rrcccc}
\hline \multicolumn{6}{c}{ composition, $\%^{a}$} \\
time & $\mathbf{1 b}$ & $(-)-\mathbf{3 b}(a)$ & $(+)-\mathbf{3 b}(b)$ & $(-)-\mathbf{2 b}(c)$ & $(+)-\mathbf{2 b}(d)$ \\
\hline $6 \mathrm{~h}$ & 27 & 38.7 & 13.3 & 13.2 & 7.8 \\
$24 \mathrm{~h}$ & 0 & 40.3 & 5.7 & 30.0 & 24.0 \\
\hline
\end{tabular}

${ }^{a}$ Compositions of each compound were determined by ${ }^{1} \mathrm{H}$ NMR spectra of the reaction mixture. 


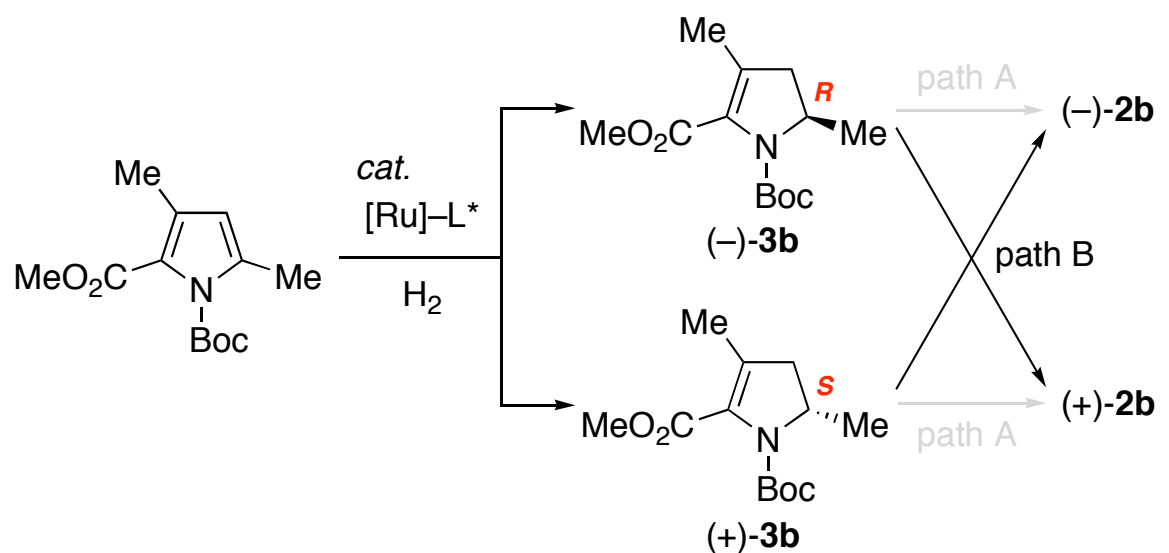

Scheme S-1. Two possible pathways to the formation of $\mathbf{2} \mathbf{b}$.

\section{References}

(1) Schrock, R. R.; Johnson, B. F. G.; Lewis, J. J. Chem. Soc., Dalton Trans. 1974, 951-959.

(2) Sawamura, M.; Hamashima, H.; Sugawara, M.; Kuwano, R.; Ito, Y. Organometallics 1995, 14, 4549-4558; Kuwano, R.; Sawamura, M. In Catalysts for Fine Chemical Synthesis, Volume 5: Regioand Stereo- Controlled Oxidations and Reductions, Roberts, S. M.; Whittall, J., Eds.; John Wiley \& Sons: West Sussex, 2007; pp 73-86.

(3) Schieweck, F.; Altenbach, H.-J. J. Chem. Soc., Perkin Trans. 1 2001, 3409-3414; Donohoe, T. J.; Guyo, P. M. J. Org. Chem. 1996, 61, 7664-7665.

(4) Boiadjiev, S. E.; Lightner, D. A. Tetrahedron: Asymmetry 2002, 13, 1721-1732.

(5) Koshiyama, T.; Shinmi, H. Jpn. Kokai Tokkyo Koho, JP2004339176, Dec 2, 2004.

(6) Dalton, C. R.; Kane, J. M.; Rampe, D. Tetrahedron Lett. 1992, 33, 5713-5716.

(7) Roomi, M. W.; MacDonald, S. F. Can. J. Chem. 1970, 48, 1689-1697.

(8) Wallace, M. PCT Int. Appl., WO2005042484, May 12, 2005.

(9) Genet, J. P.; Pinel, C.; Mallart, S.; Juge, S.; Thorimbert, S.; Laffitte, J. A. Tetrahedron: Asymmetry 1991, 2, 555-567.

(10) Mattson, A. E.; Bharadwaj, A. R.; Zuhl, A. M.; Scheidt, K. A. J. Org. Chem. 2006, 71, 5715-5724.

(11) Yuste, F.; Ortiz, B.; Carrasco, A.; Peralta, M.; Quintero, L.; Sánchez-Obregón, R.; Walls, F.; Ruano, J. L. G. Tetrahedron: Asymmetry 2000, 11, 3079-3090.

(12) Belvisia, L.; Colombo, L.; Colomboa, M.; Giacomob, M. D.; Manzonia, L.; Vodopivecc, B.; Scolastico, C. Tetrahedron 2001, 57, 6453-6473. 


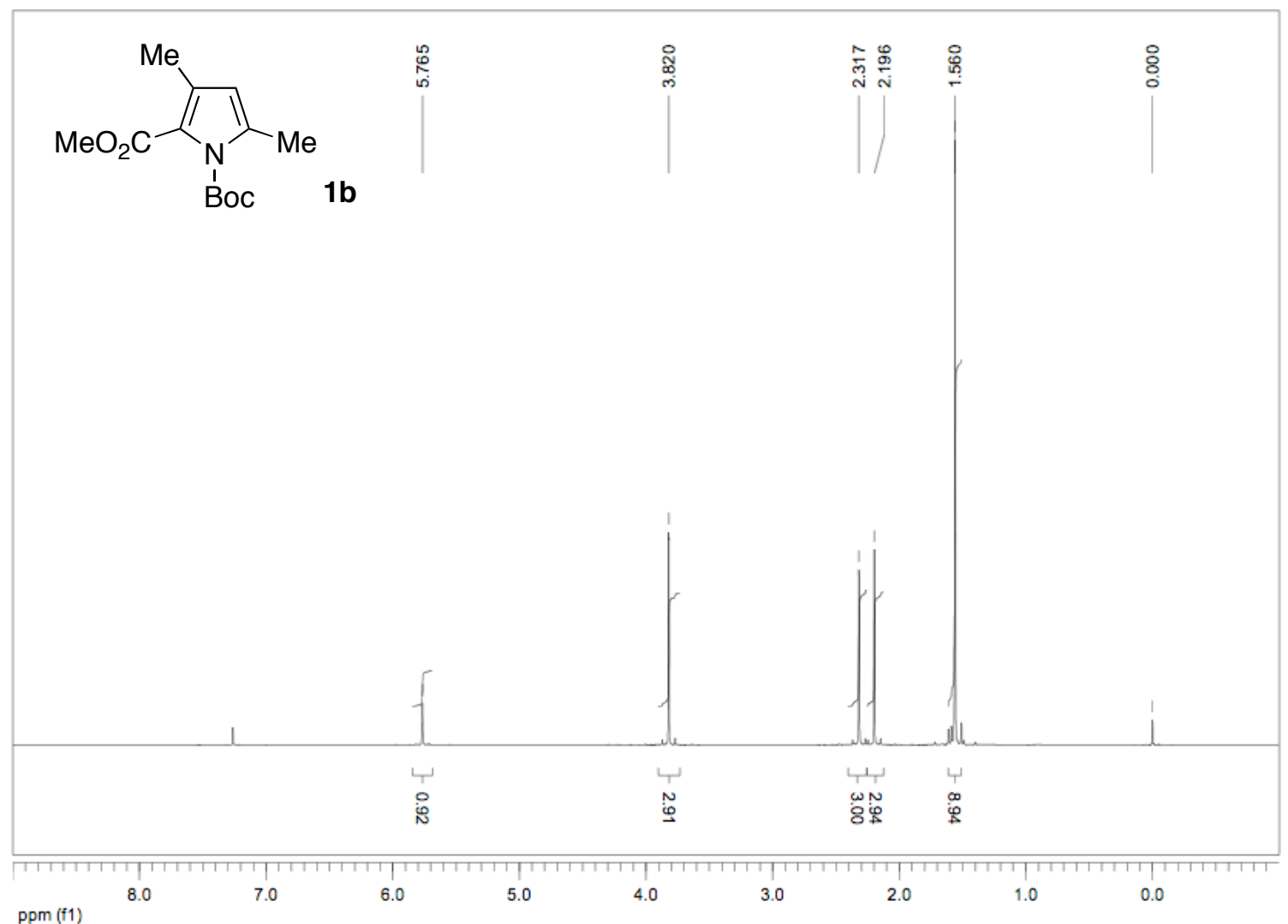

Figure S-3. $\quad{ }^{1}$ H NMR spectrum of $\mathbf{1 b}$.

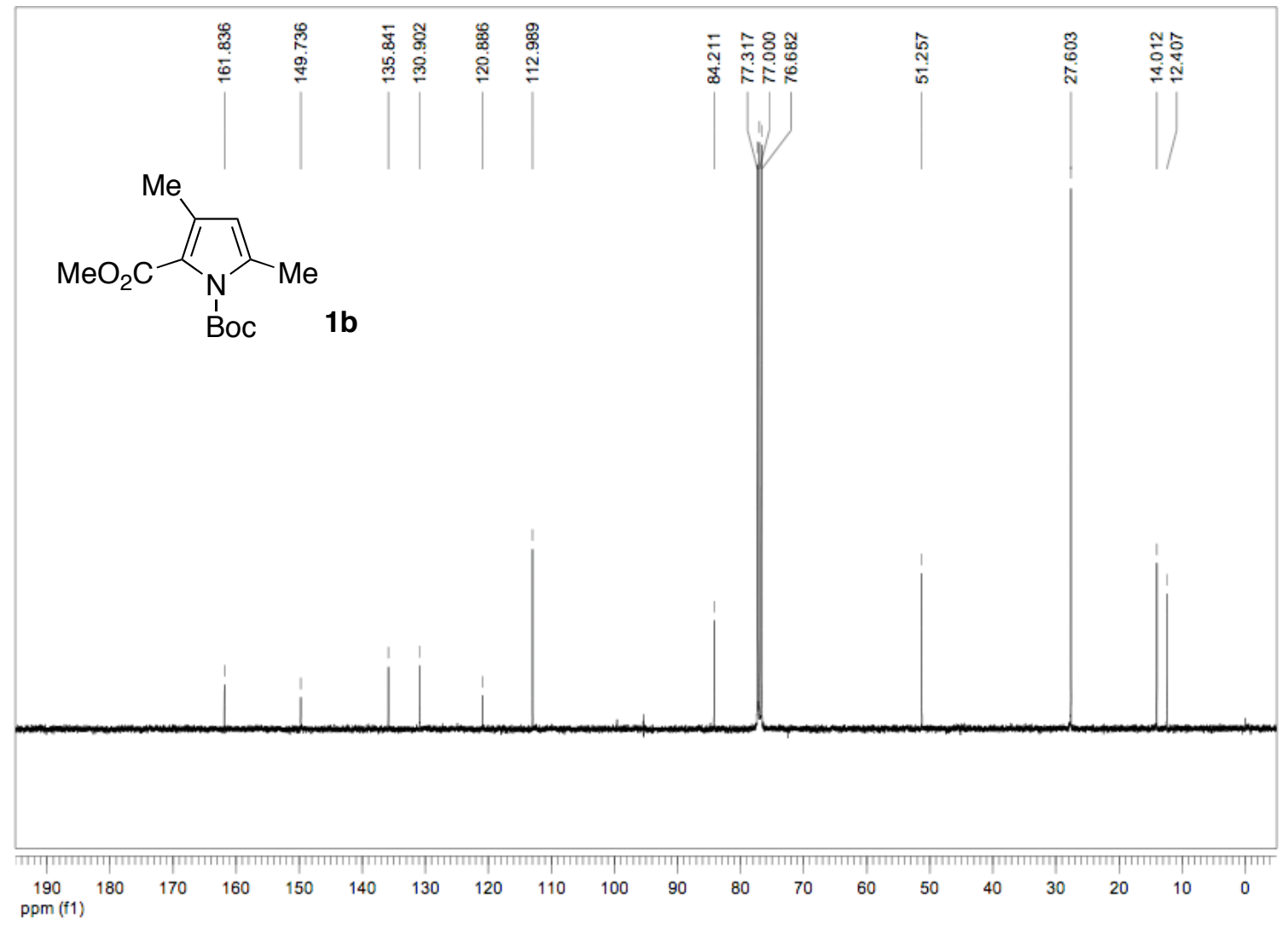

Figure S-4. ${ }^{13} \mathrm{C}\left\{{ }^{1} \mathrm{H}\right\}$ NMR spectrum of $\mathbf{1 b}$. 


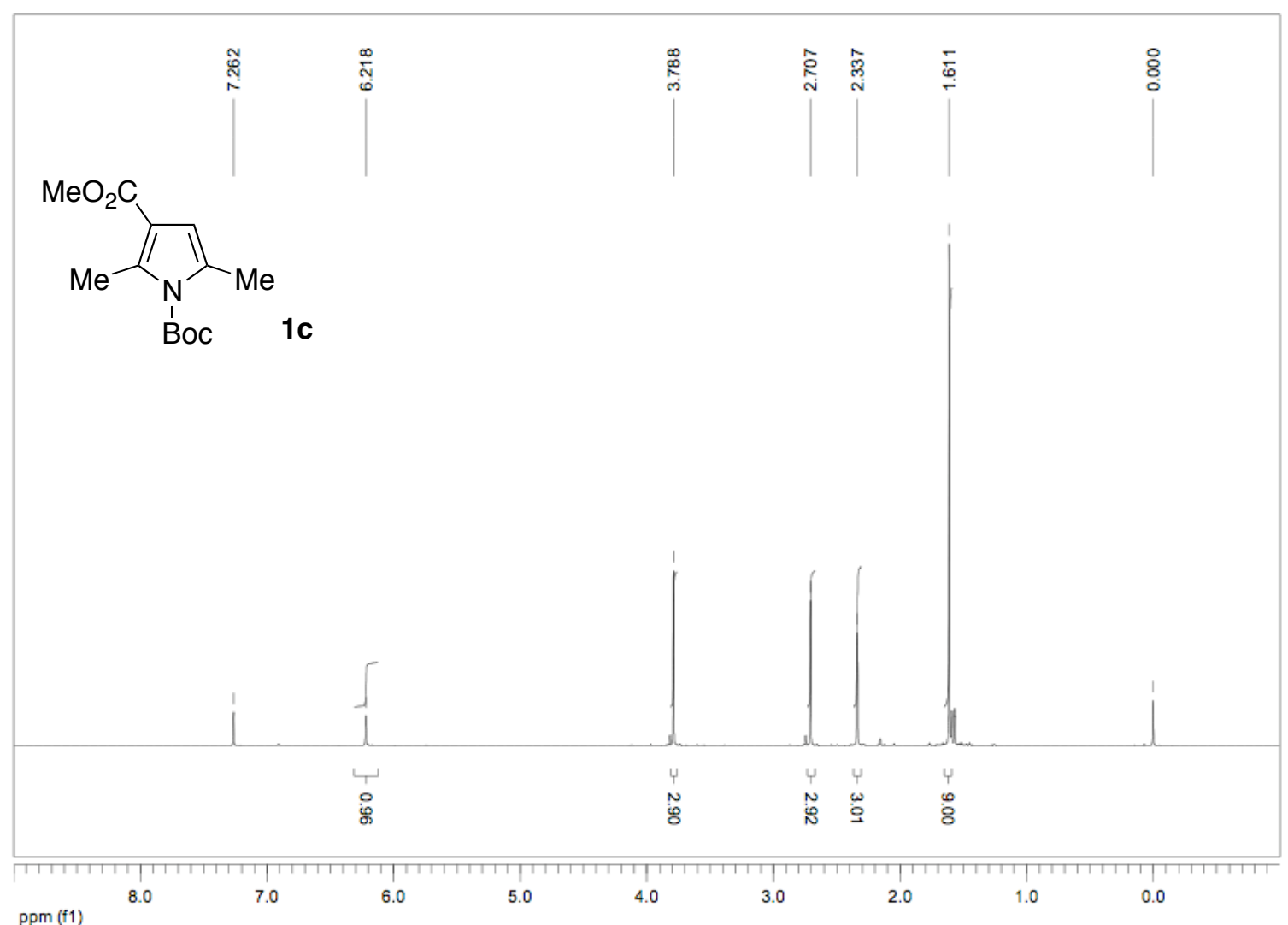

Figure S-5. ${ }^{1} \mathrm{H}$ NMR spectrum of 1 c.

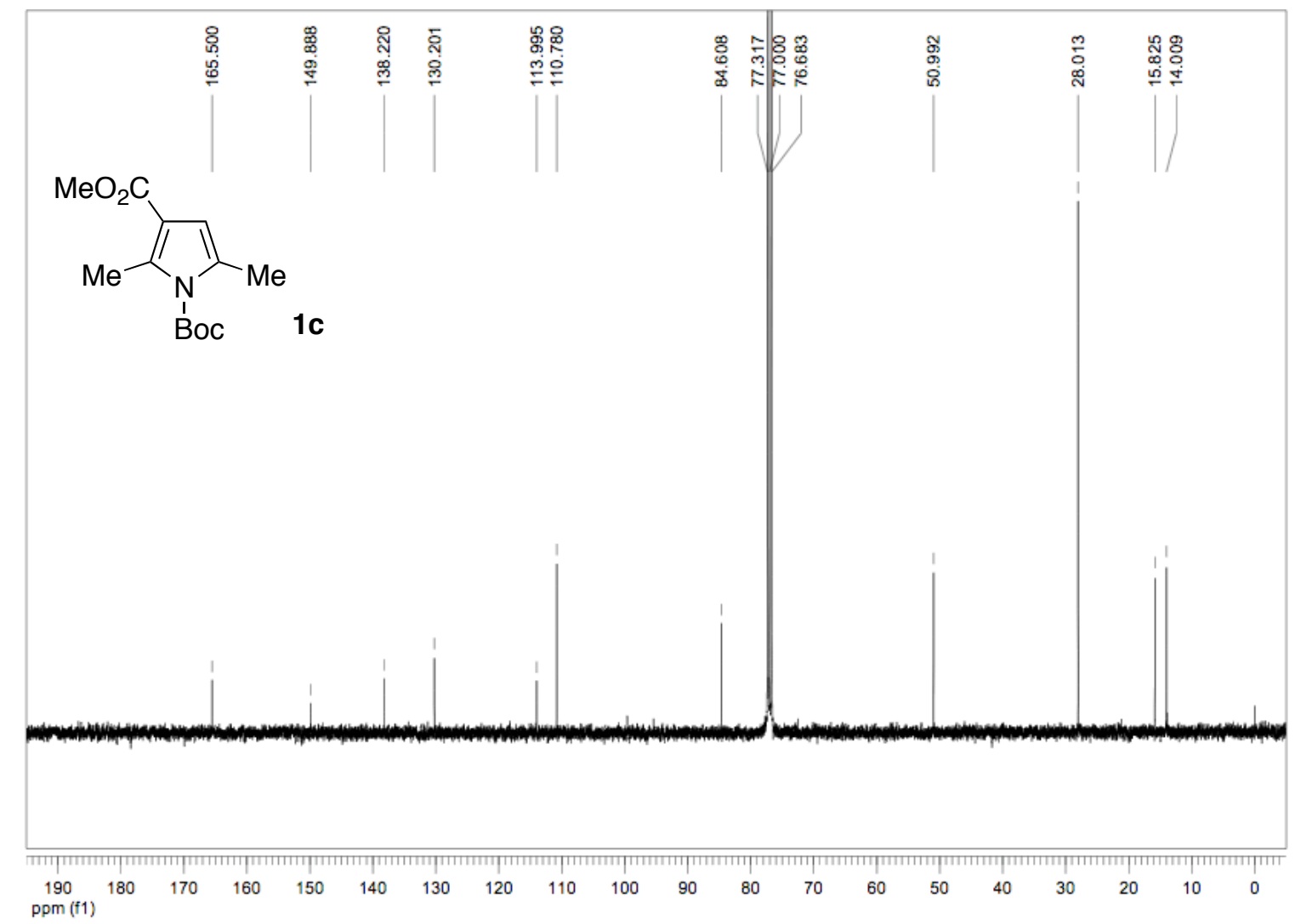

Figure S-6. ${ }^{13} \mathrm{C}\left\{{ }^{1} \mathrm{H}\right\}$ NMR spectrum of 1 c. 


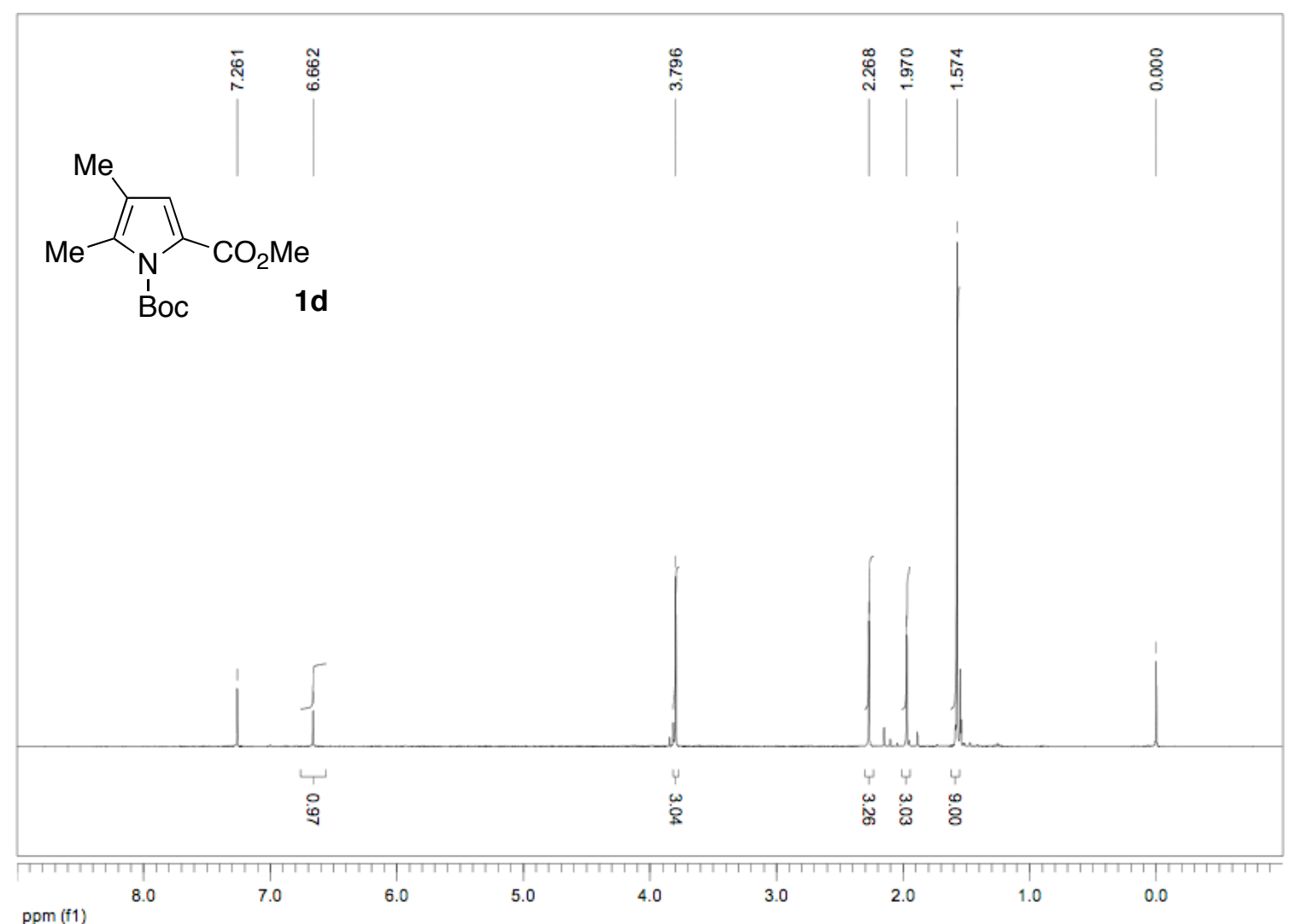

Figure S-7. $\quad{ }^{1}$ H NMR spectrum of $1 d$.

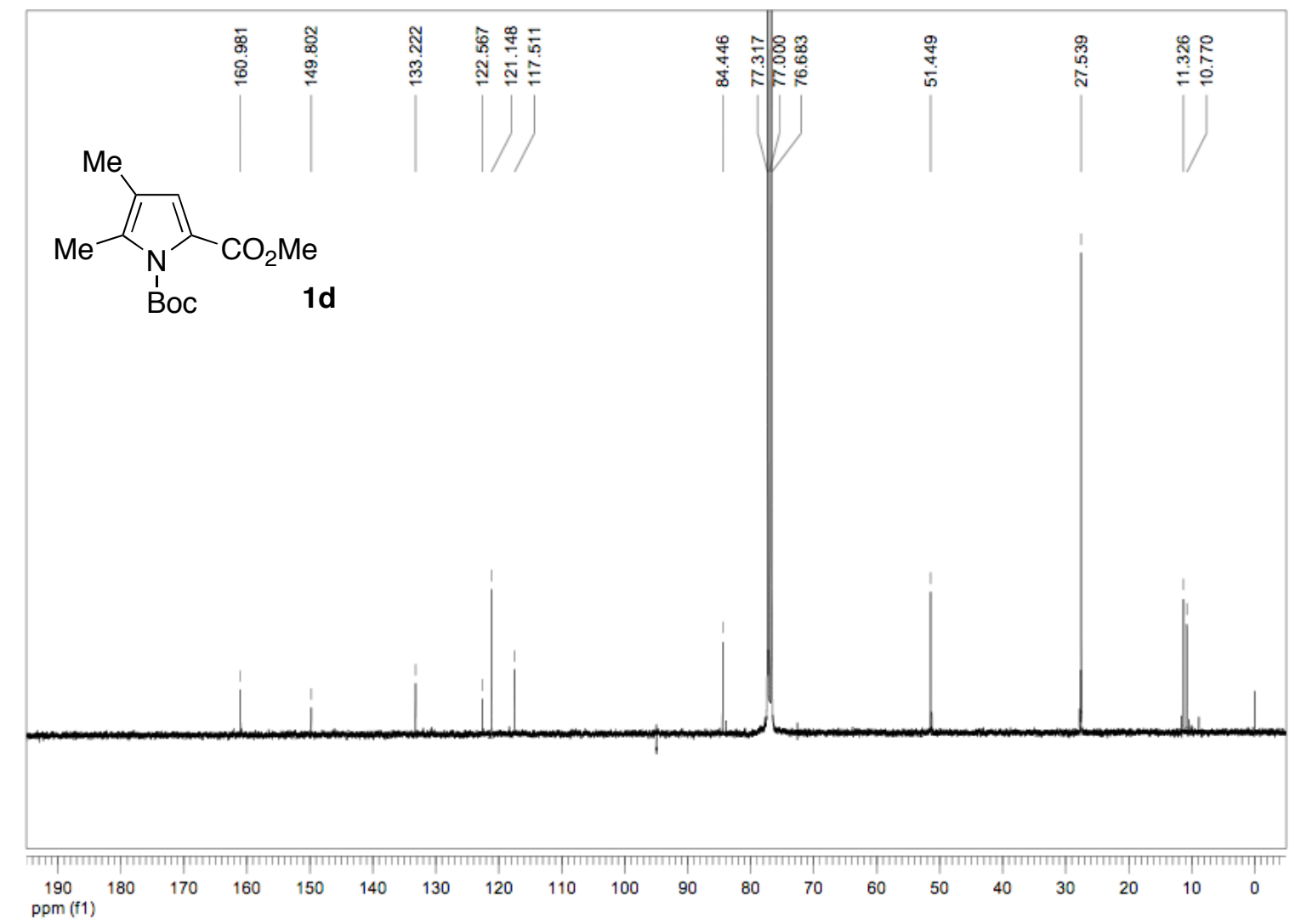

Figure S-8. ${ }^{13} \mathrm{C}\left\{{ }^{1} \mathrm{H}\right\}$ NMR spectrum of $\mathbf{1 d}$. 


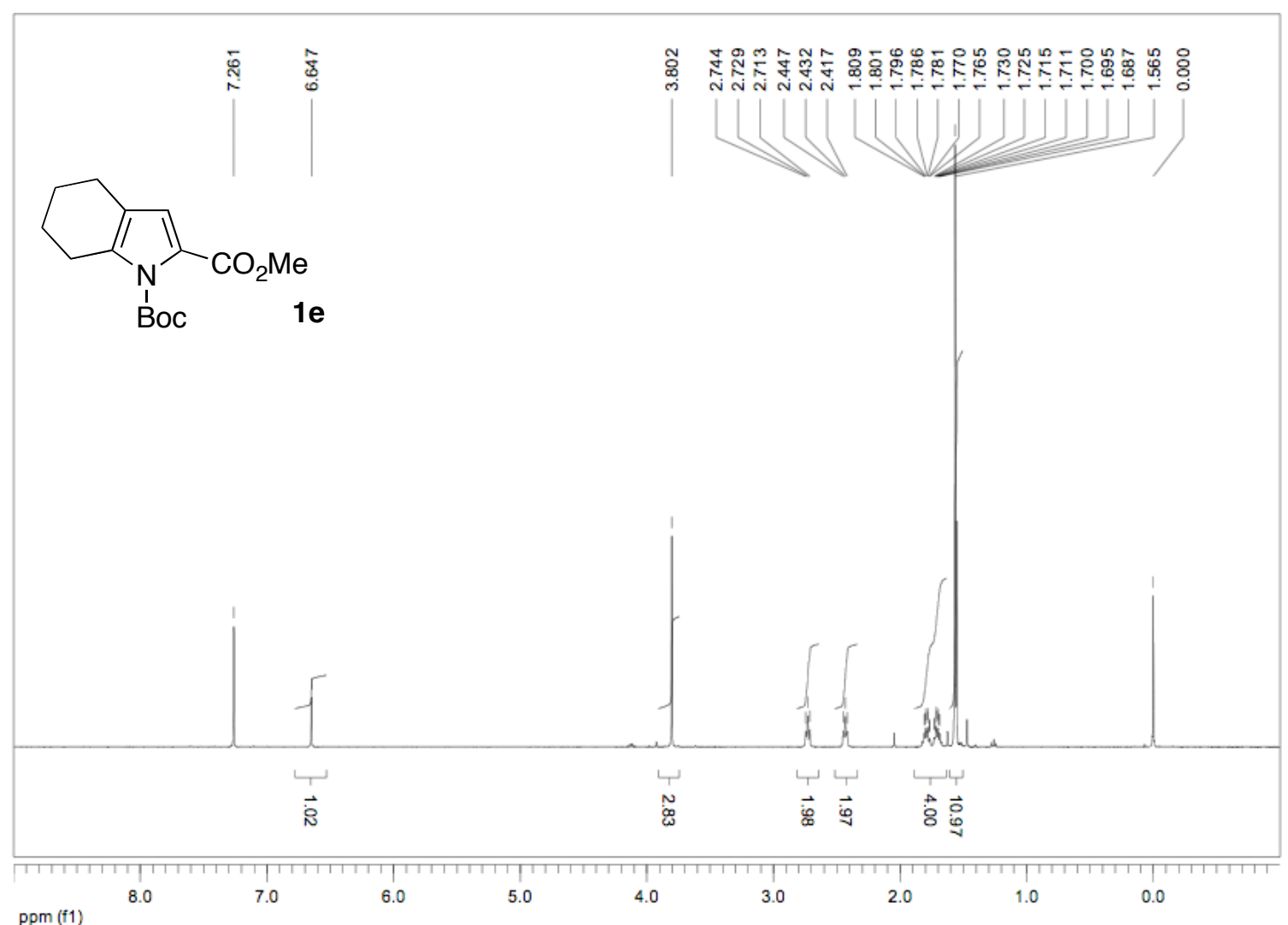

Figure S-9. ${ }^{1}$ H NMR spectrum of $1 \mathbf{e}$.

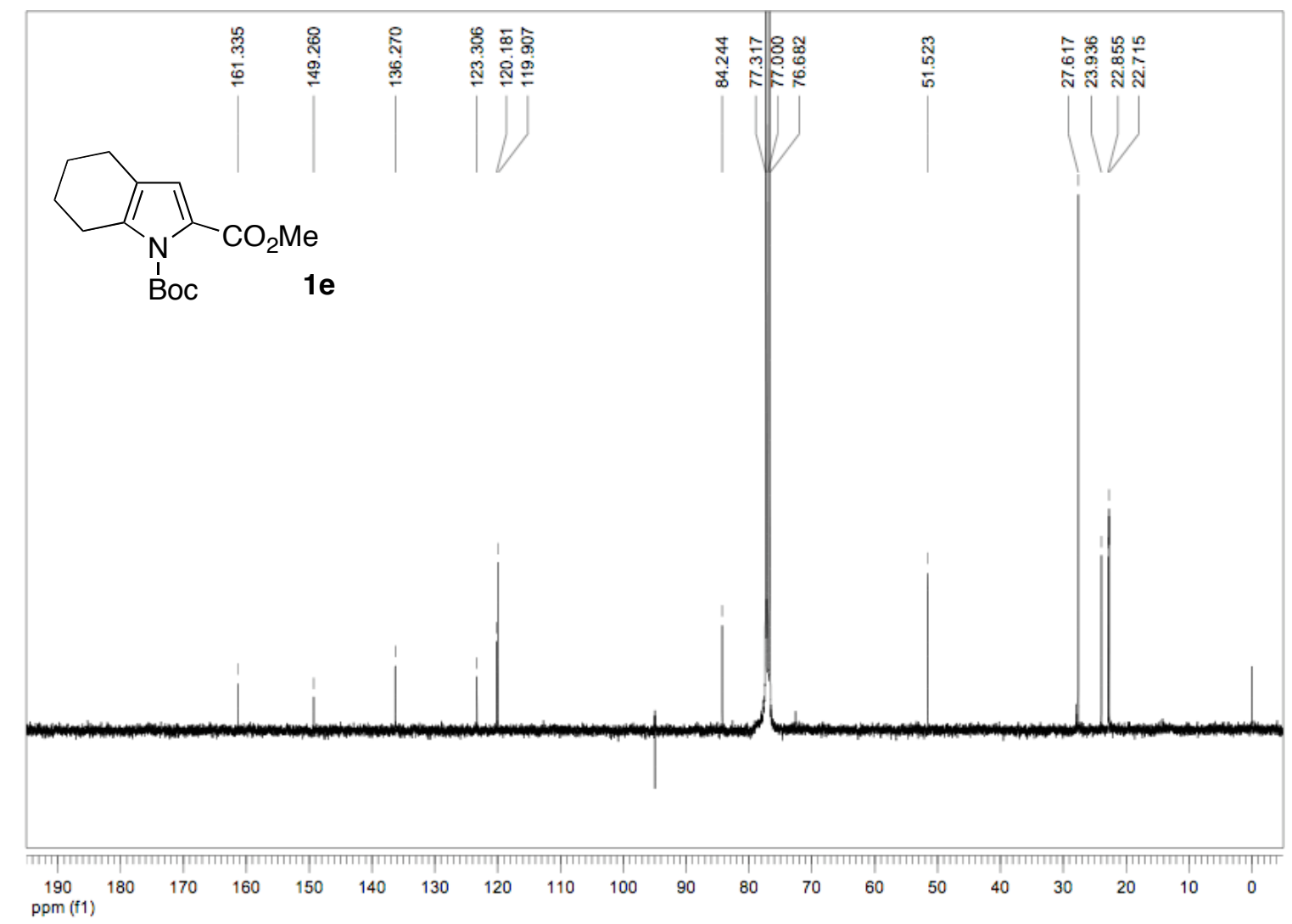

Figure S-10. ${ }^{13} \mathrm{C}\left\{{ }^{1} \mathrm{H}\right\}$ NMR spectrum of $\mathbf{1 e}$. 


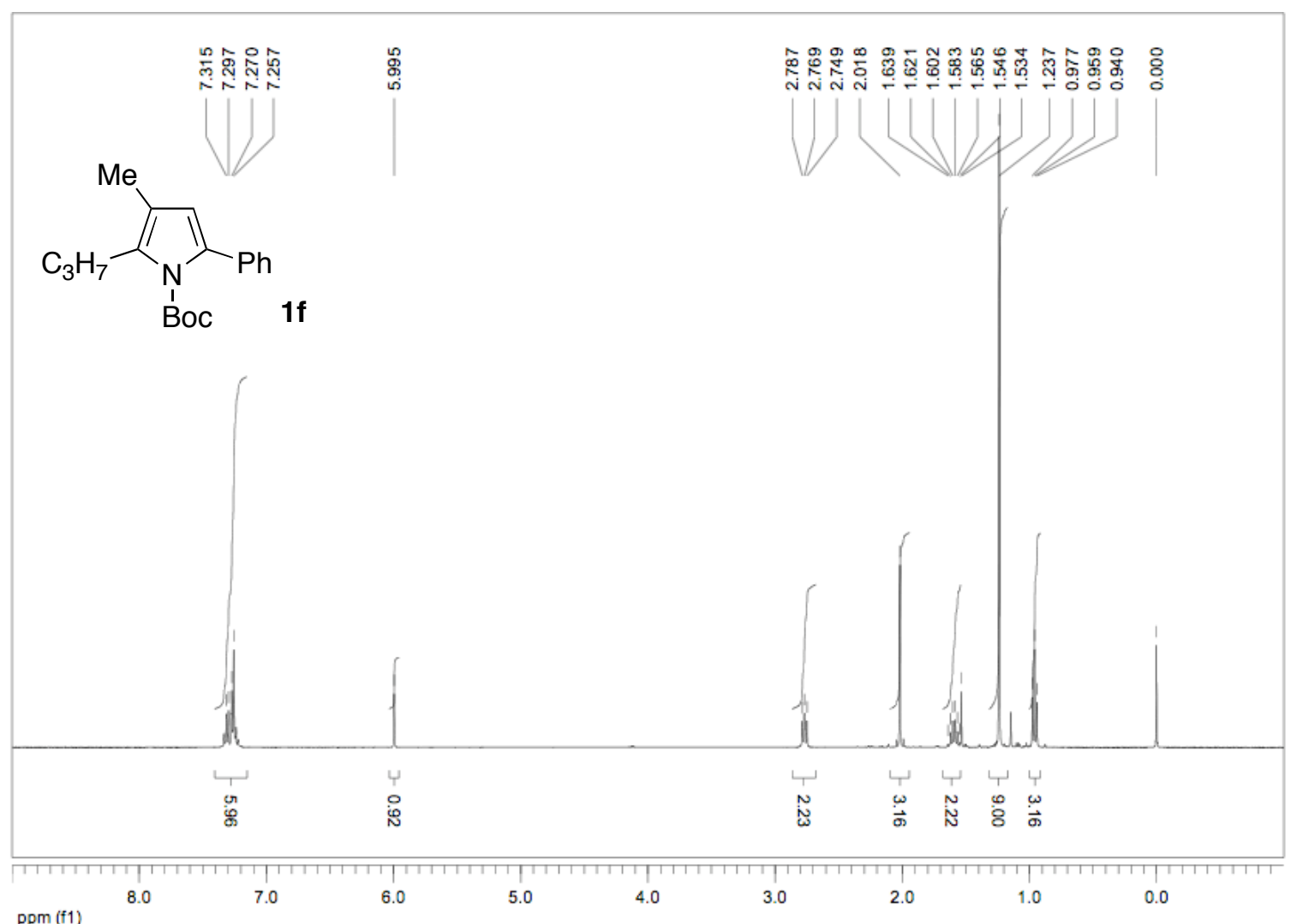

Figure S-11. $\quad{ }^{1} \mathrm{H}$ NMR spectrum of $\mathbf{1 f}$.

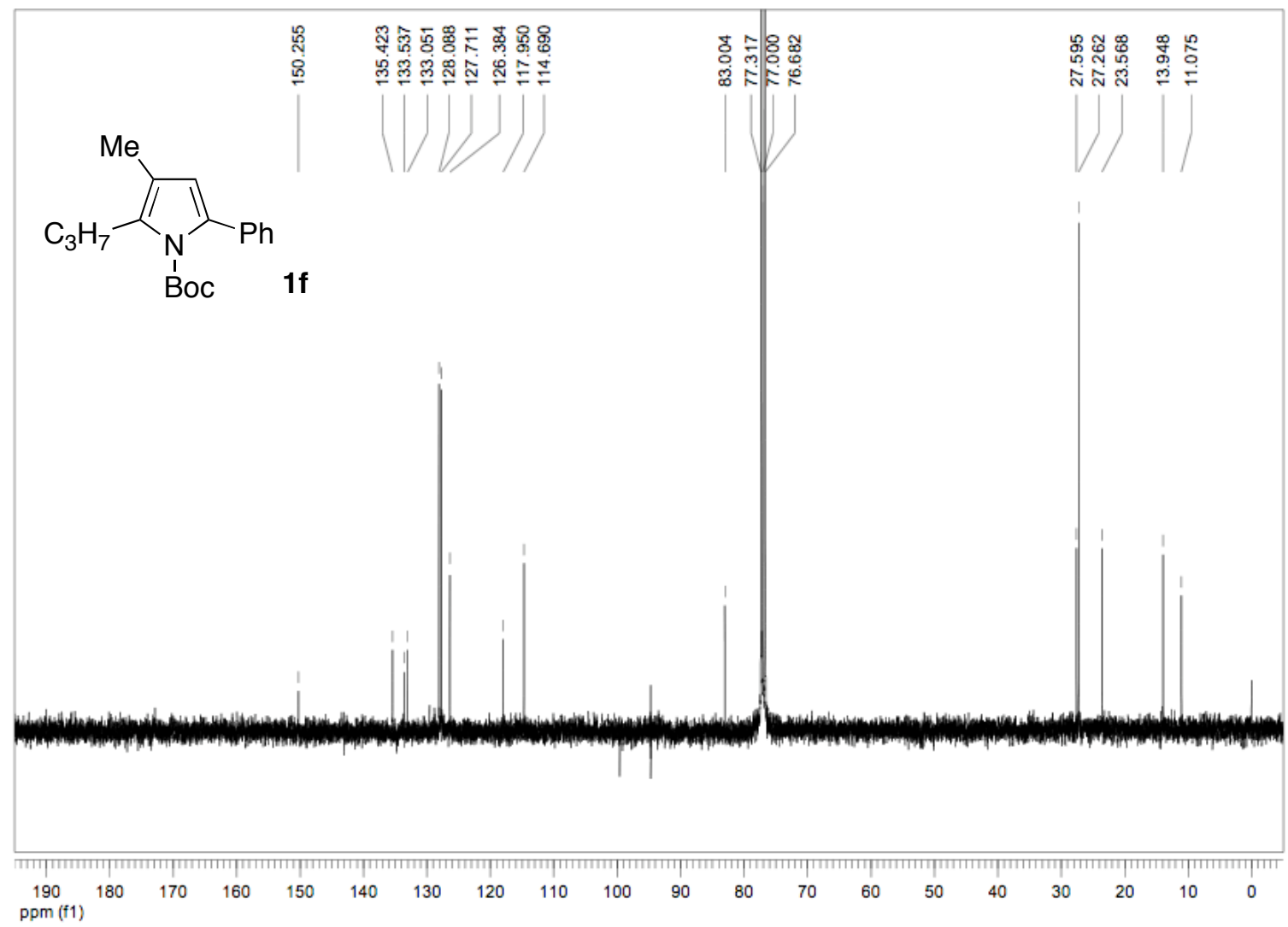

Figure S-12. ${ }^{13} \mathrm{C}\left\{{ }^{1} \mathrm{H}\right\}$ NMR spectrum of $\mathbf{1 f}$. 


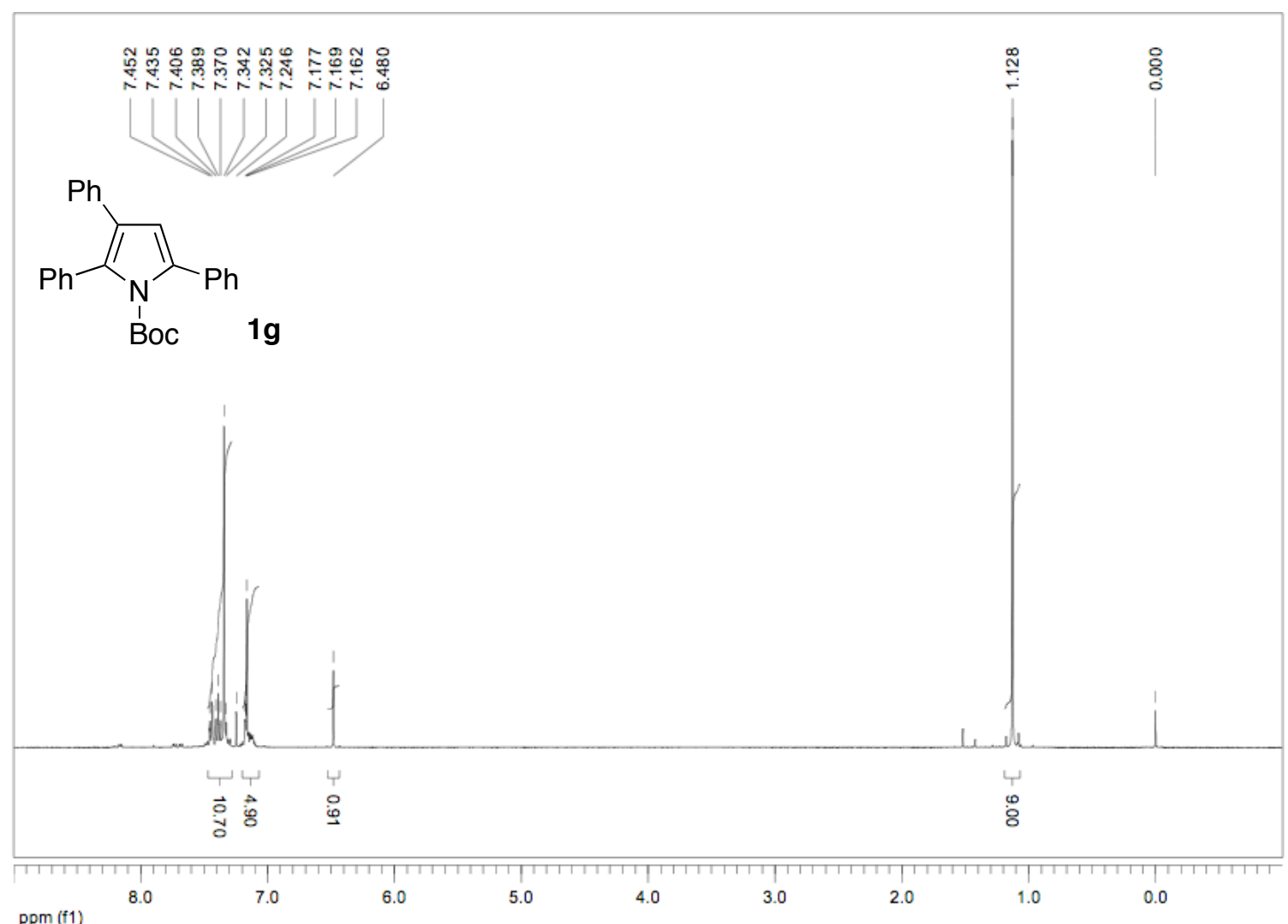

Figure S-13. $\quad{ }^{1} \mathrm{H}$ NMR spectrum of $\mathbf{1 g}$.

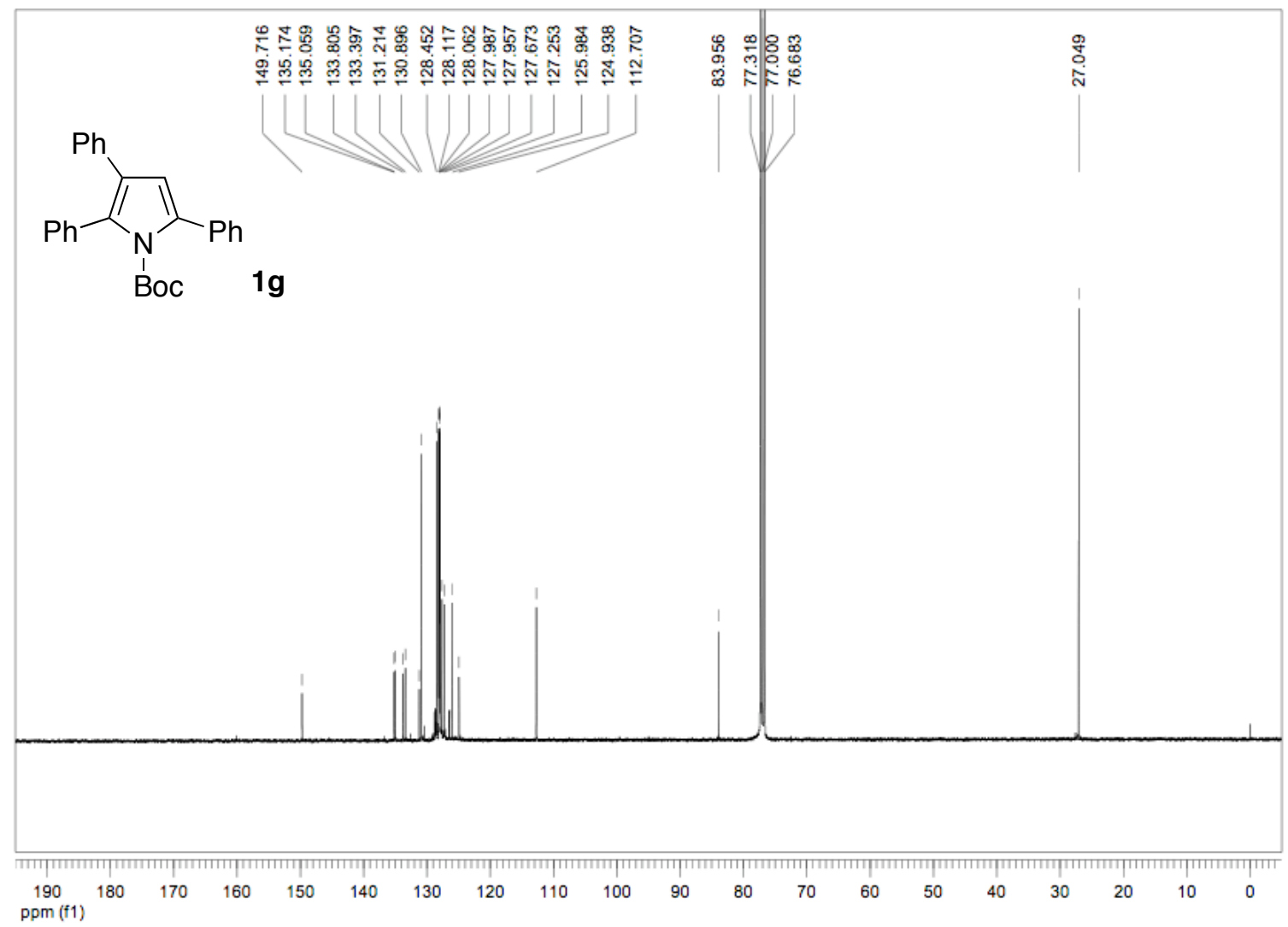

Figure S-14. ${ }^{13} \mathrm{C}\left\{{ }^{1} \mathrm{H}\right\}$ NMR spectrum of $\mathbf{1 g}$. 


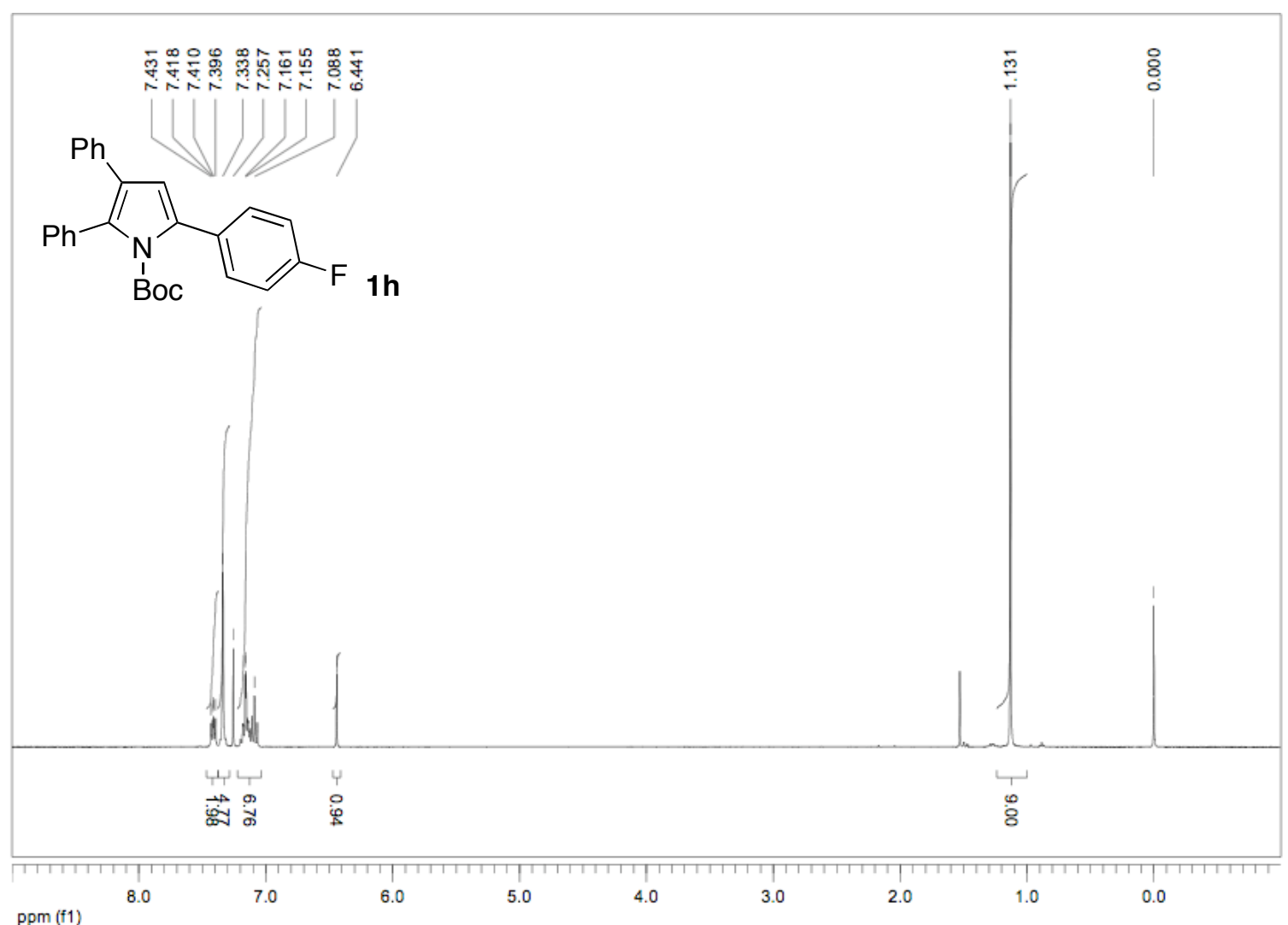

Figure S-15. $\quad{ }^{1} \mathrm{H}$ NMR spectrum of $\mathbf{1 h}$.
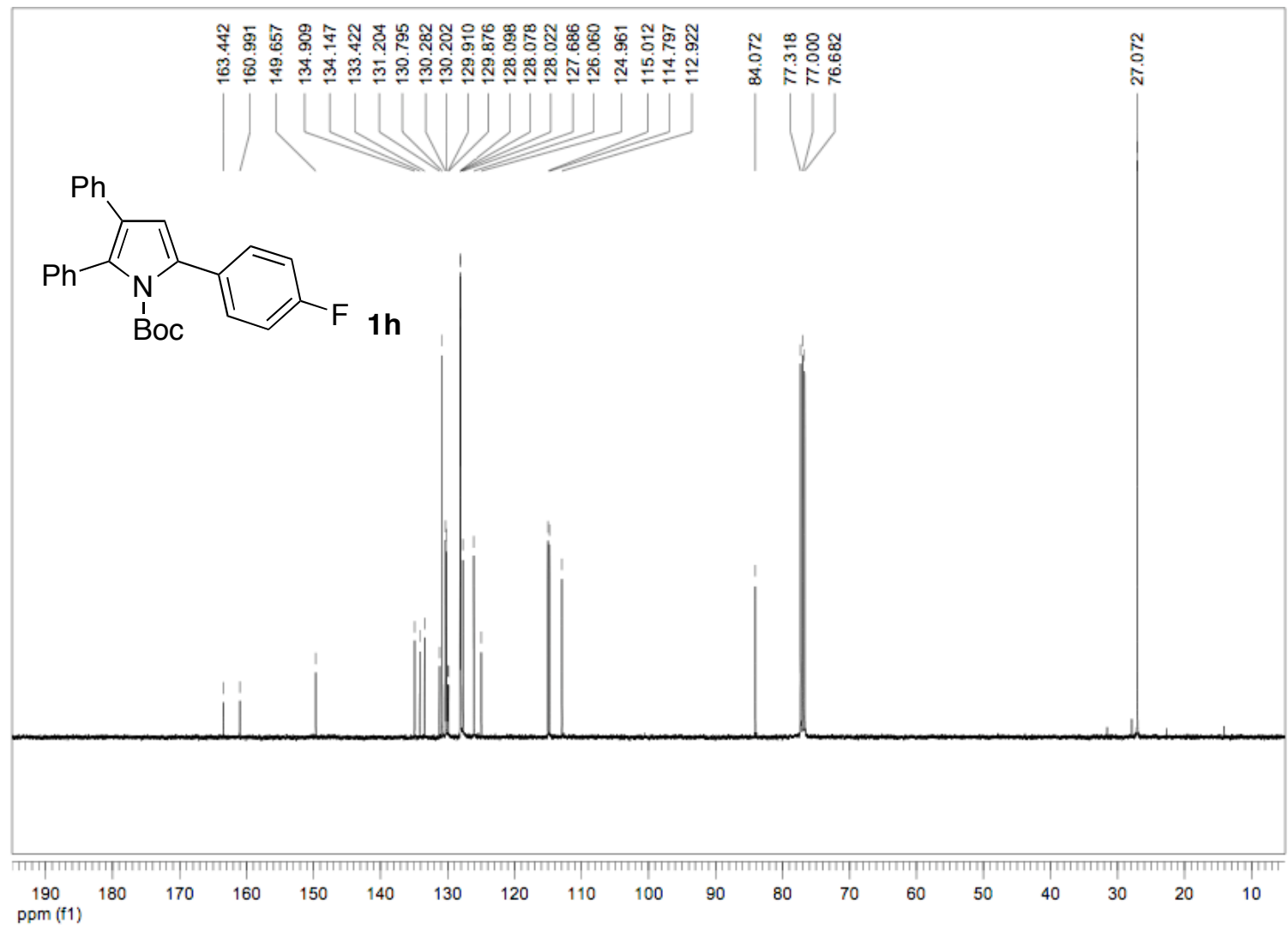

Figure S-16. ${ }^{13} \mathrm{C}\left\{{ }^{1} \mathrm{H}\right\}$ NMR spectrum of $\mathbf{1 h}$. 


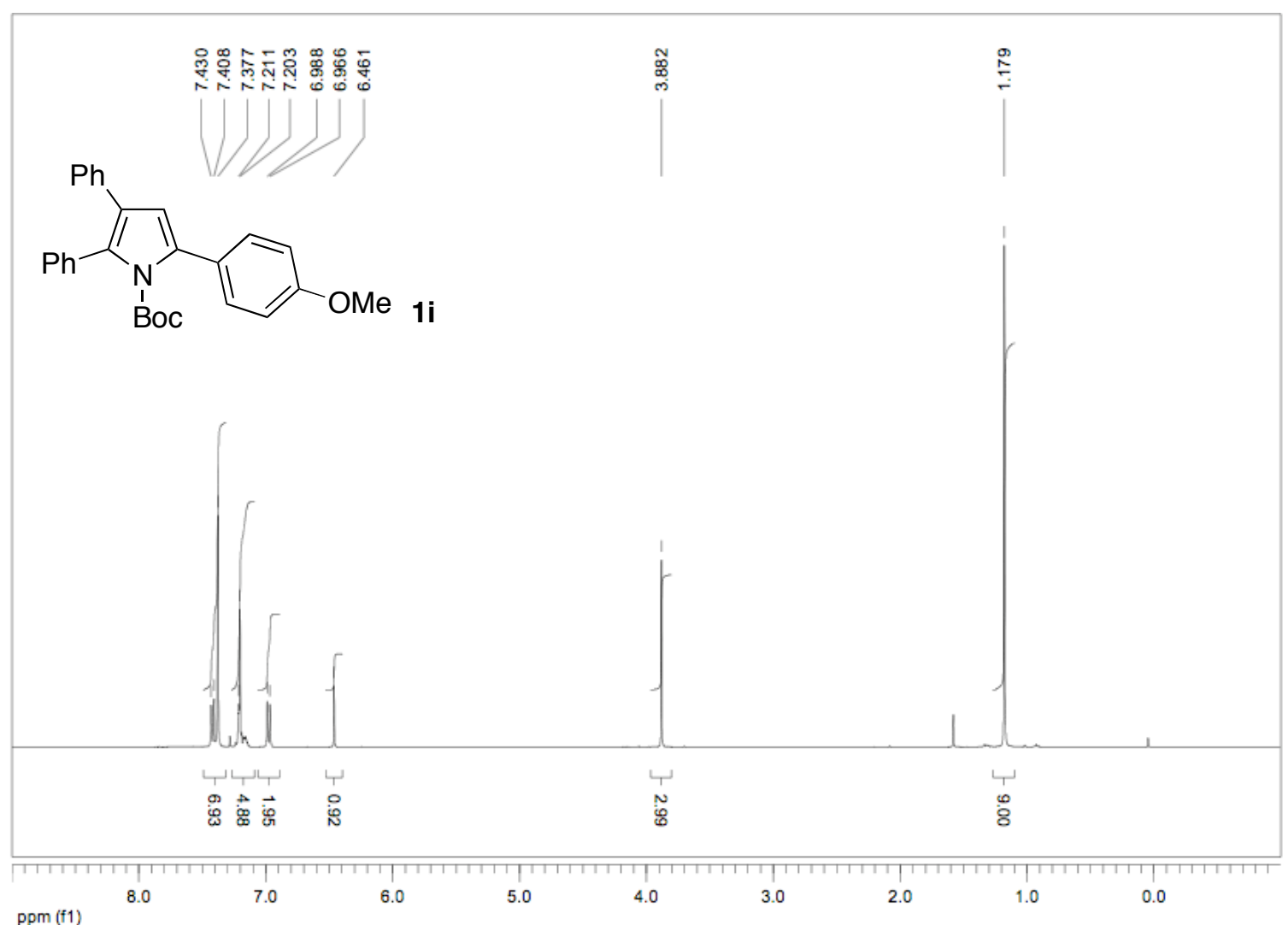

Figure S-17. $\quad{ }^{1}$ H NMR spectrum of $\mathbf{1 i}$.

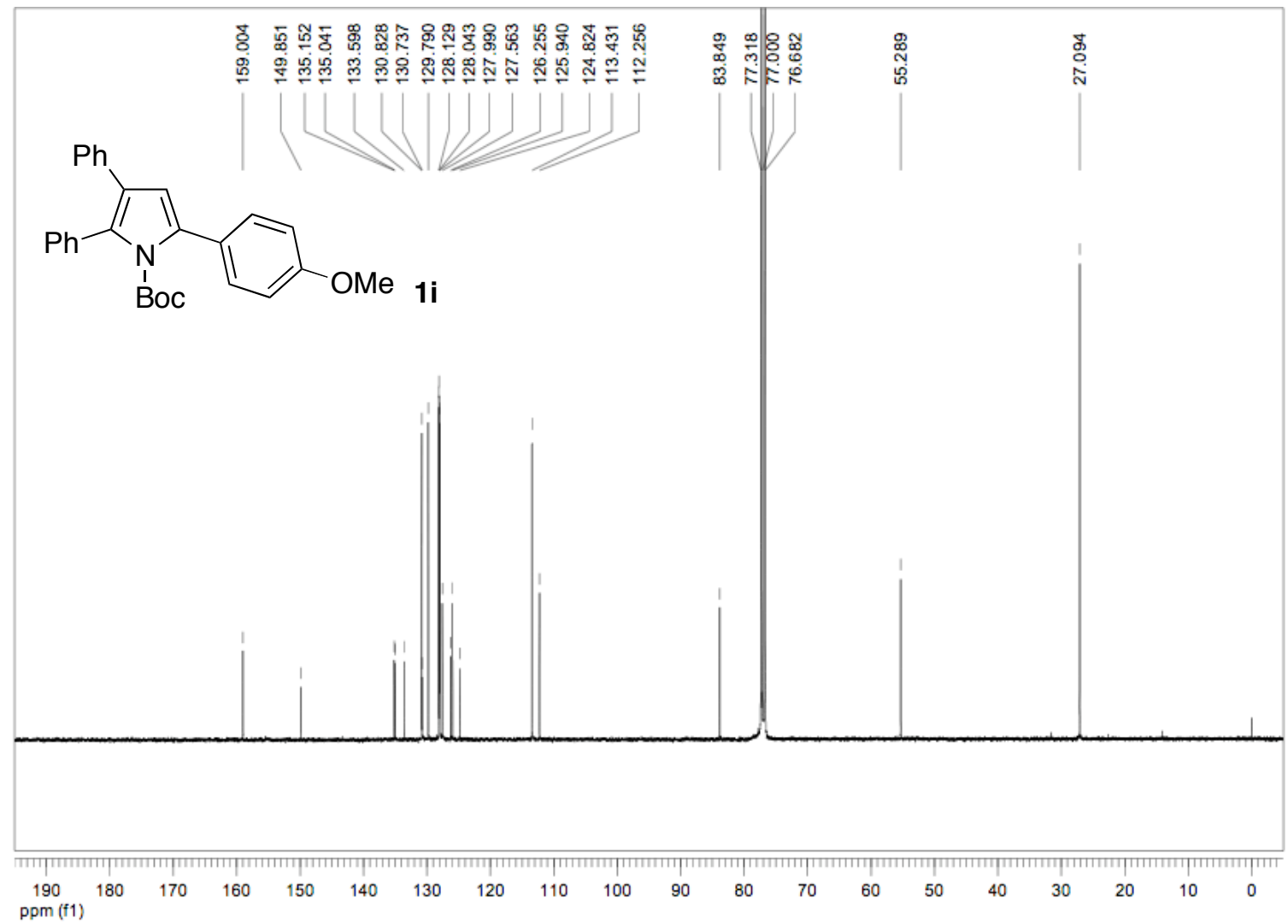

Figure S-18. ${ }^{13} \mathrm{C}\left\{{ }^{1} \mathrm{H}\right\}$ NMR spectrum of $\mathbf{1 i}$. 


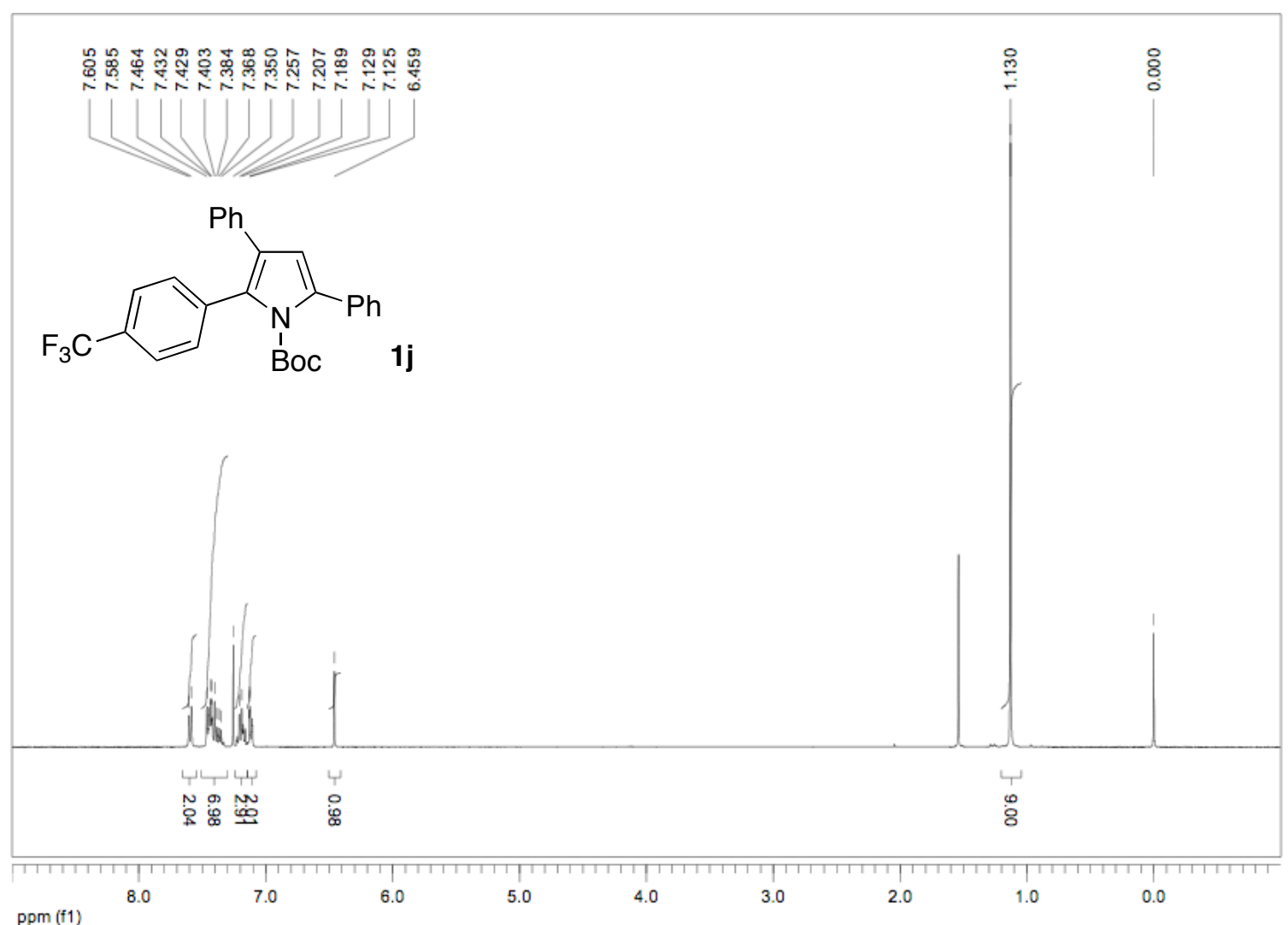

Figure S-19. ${ }^{1}$ H NMR spectrum of $\mathbf{1 j}$.

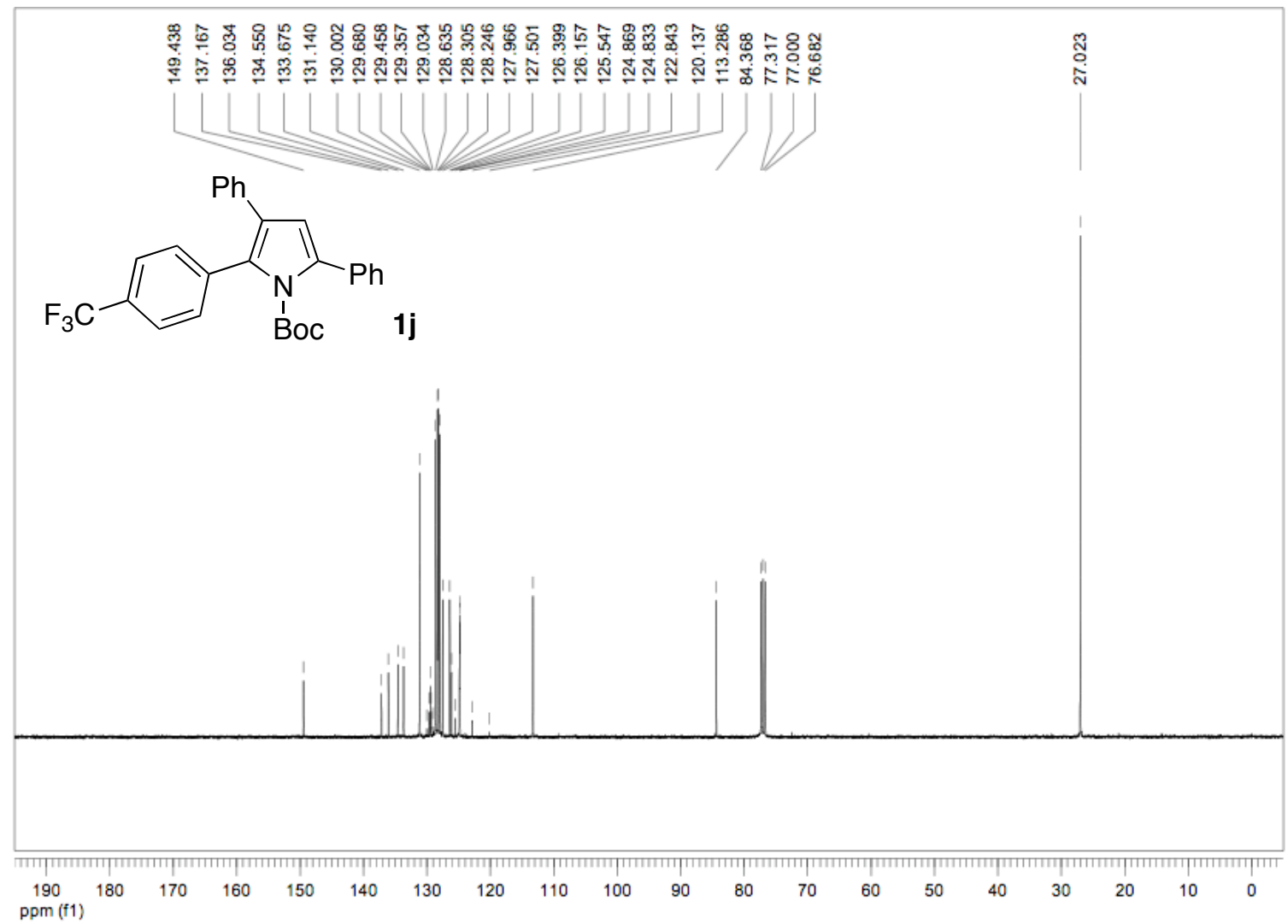

Figure S-20. ${ }^{13} \mathrm{C}\left\{{ }^{1} \mathrm{H}\right\}$ NMR spectrum of $\mathbf{1 j}$. 


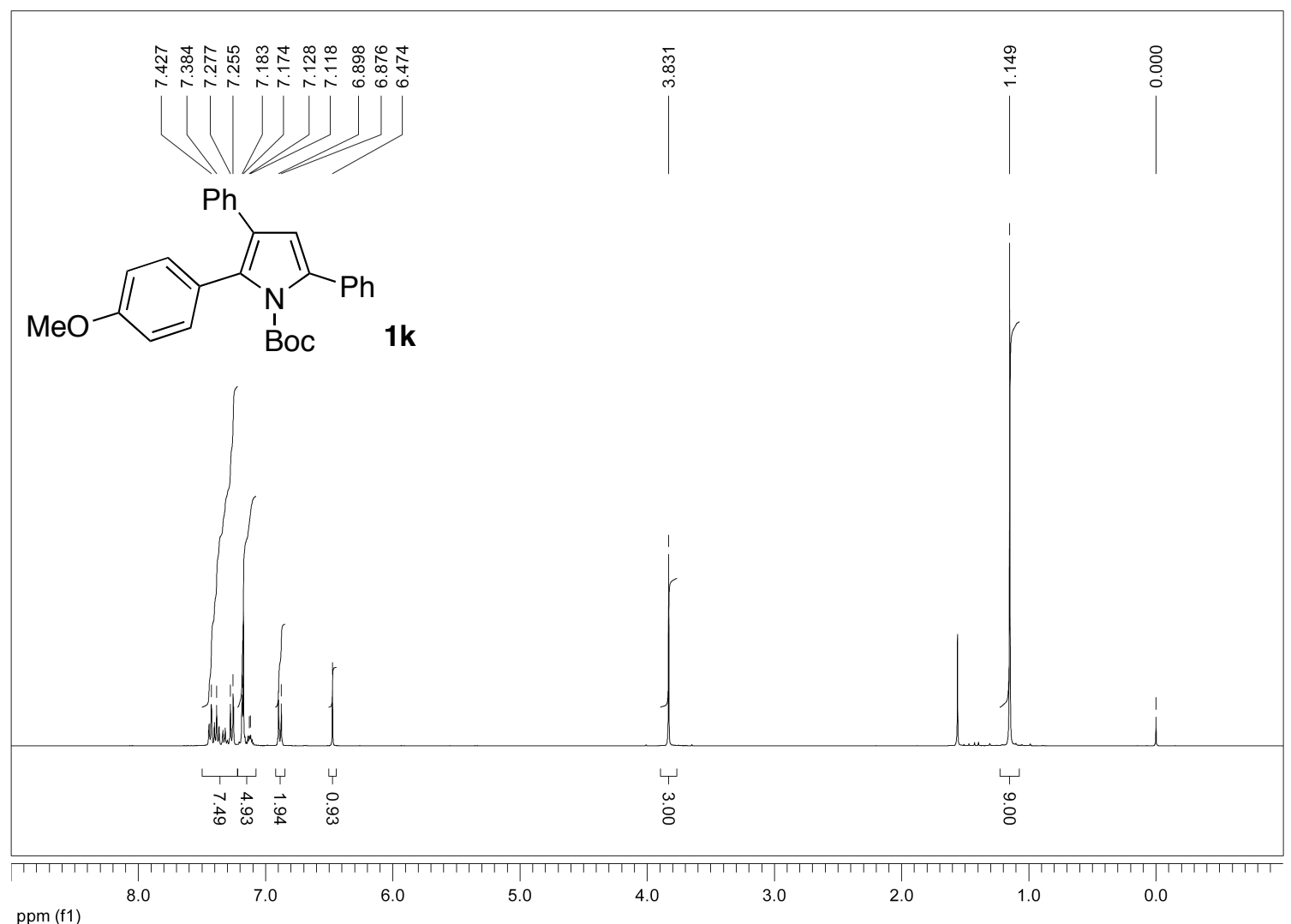

Figure S-21. ${ }^{1}$ H NMR spectrum of $\mathbf{1 k}$.

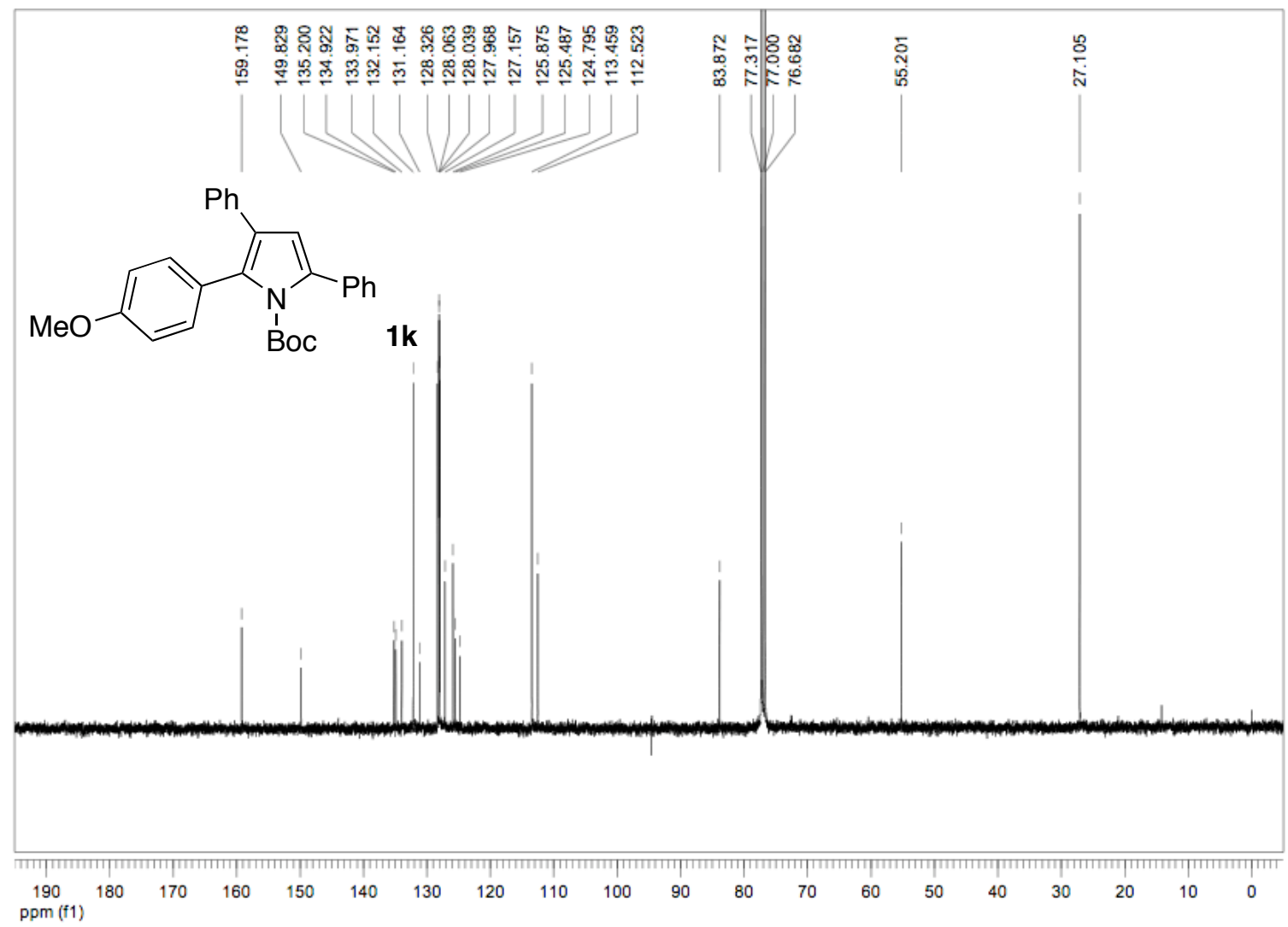

Figure S-22. ${ }^{13} \mathrm{C}\left\{{ }^{1} \mathrm{H}\right\}$ NMR spectrum of $\mathbf{1 k}$. 


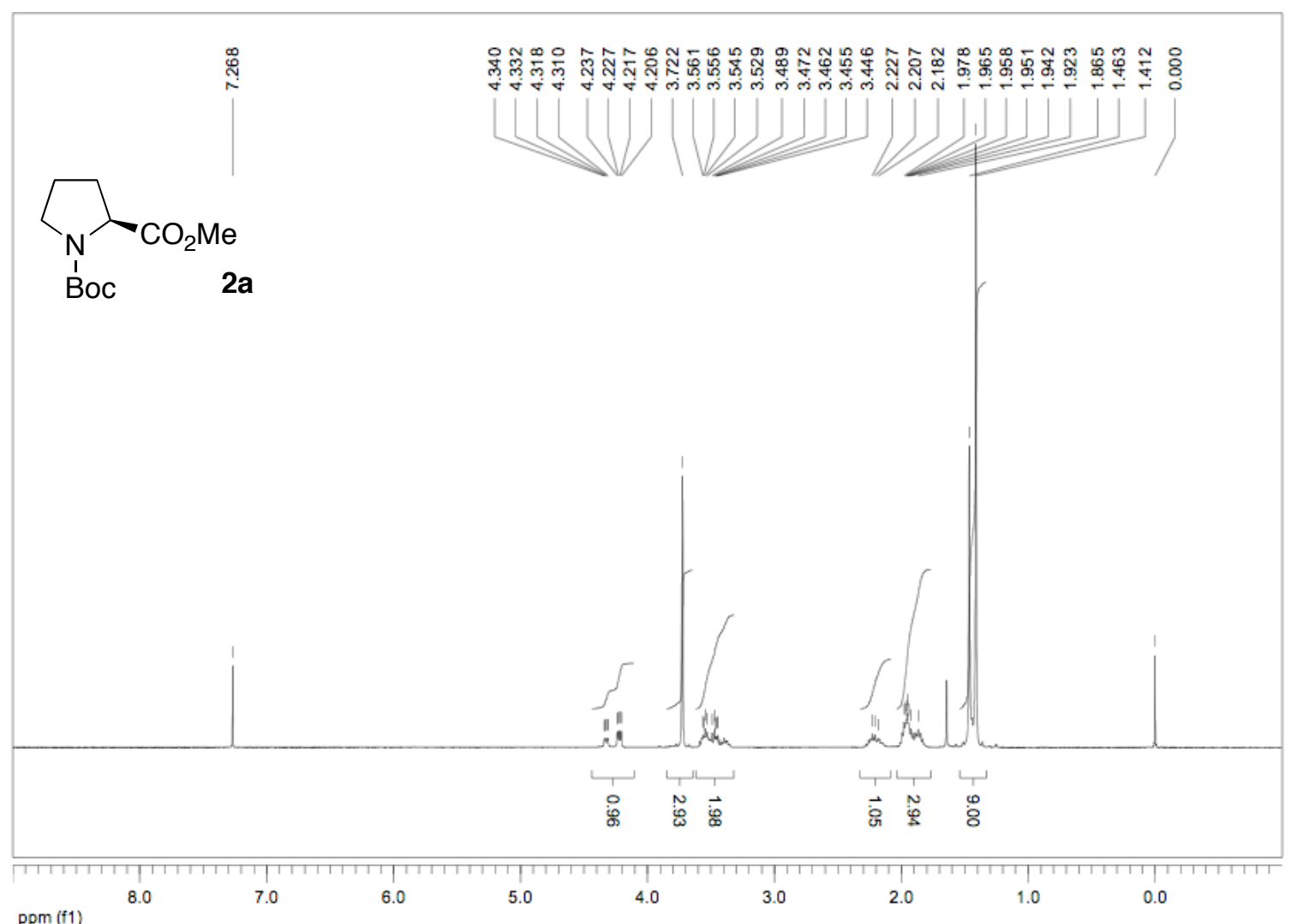

Figure S-23. $\quad{ }^{1} \mathrm{H}$ NMR spectrum of $\mathbf{2 a}$.

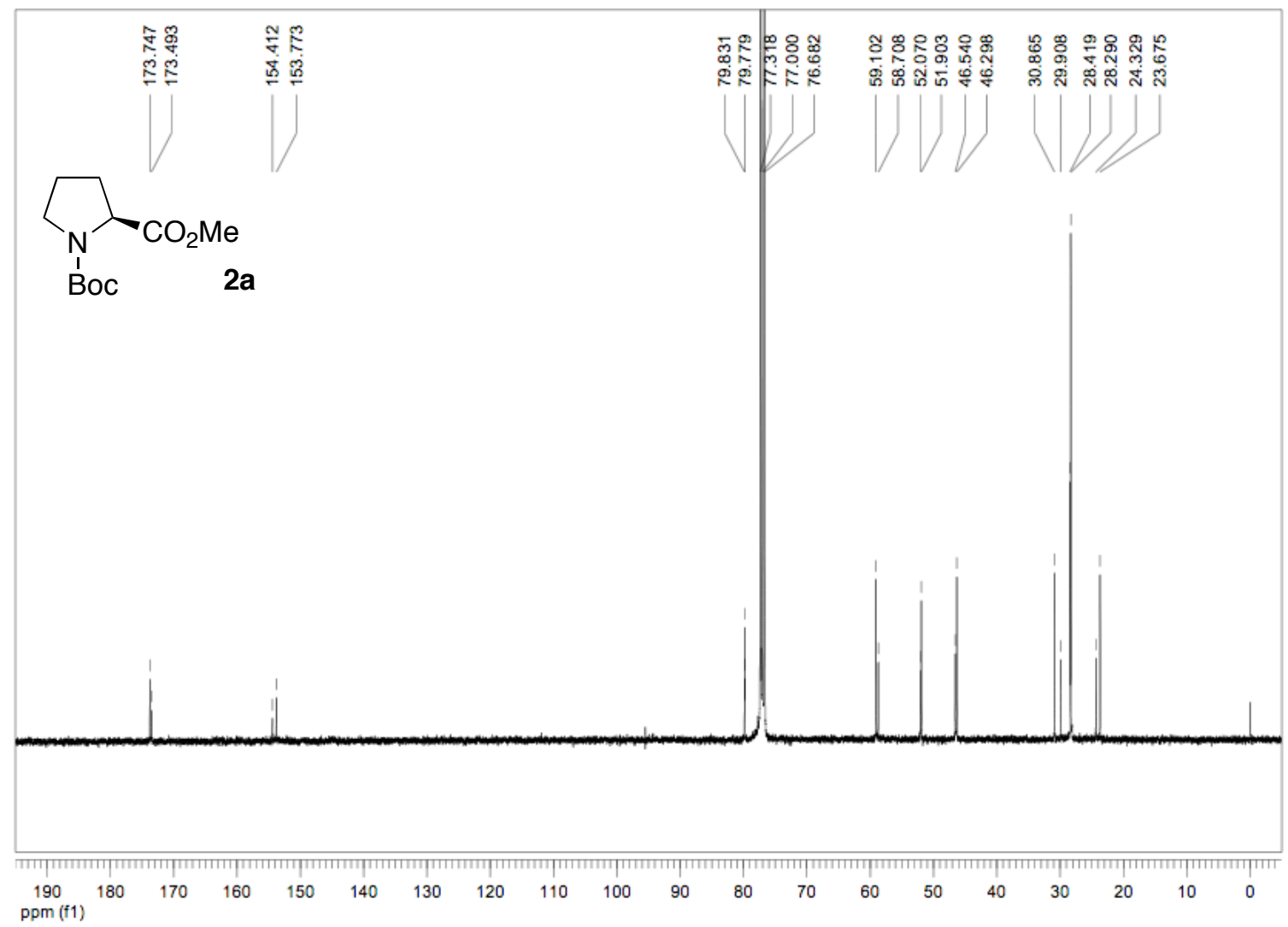

Figure S-24. ${ }^{13} \mathrm{C}\left\{{ }^{1} \mathrm{H}\right\}$ NMR spectrum of $\mathbf{2 a}$. 


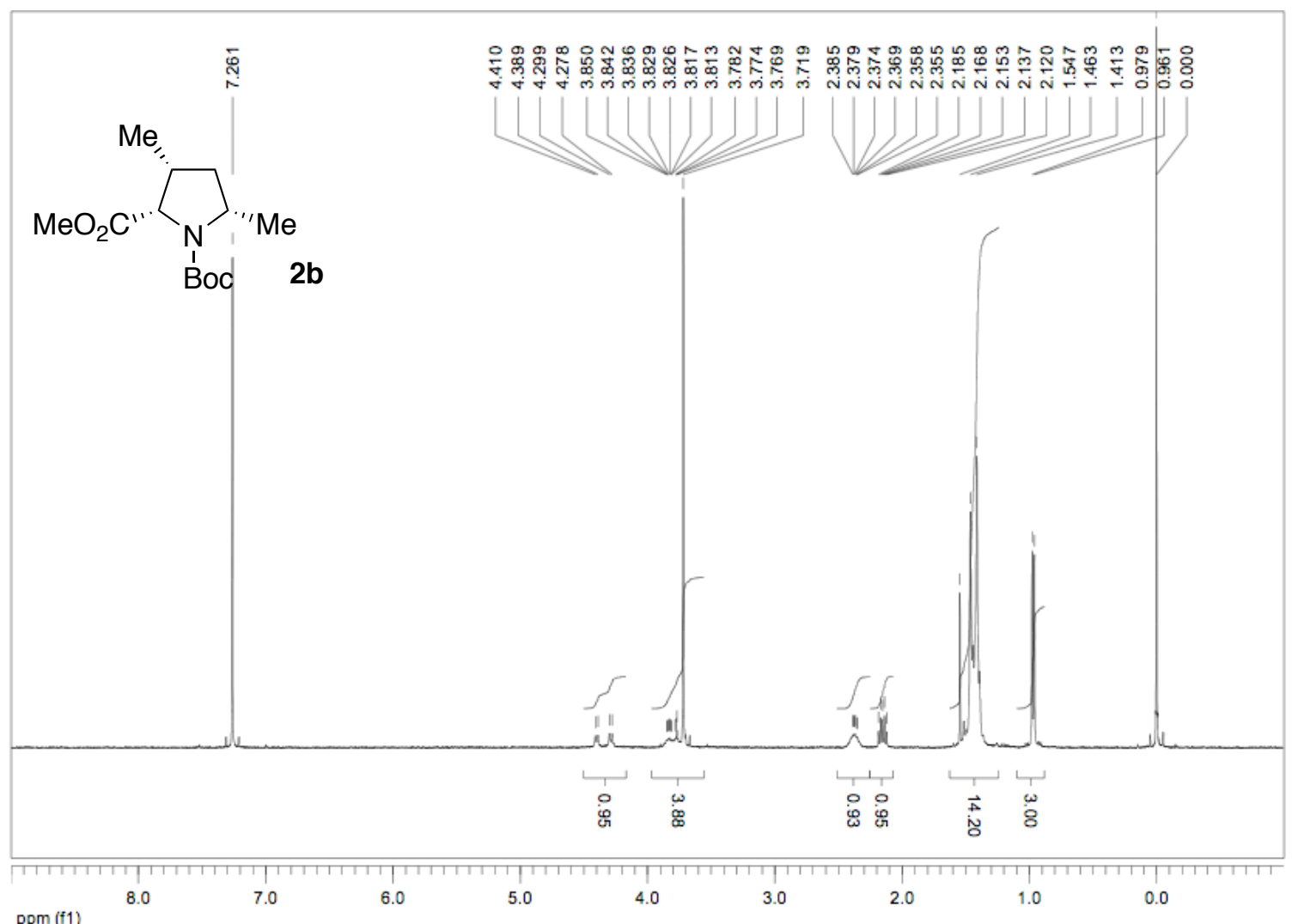

Figure S-25. $\quad{ }^{1} \mathrm{H}$ NMR spectrum of $\mathbf{2 b}$.

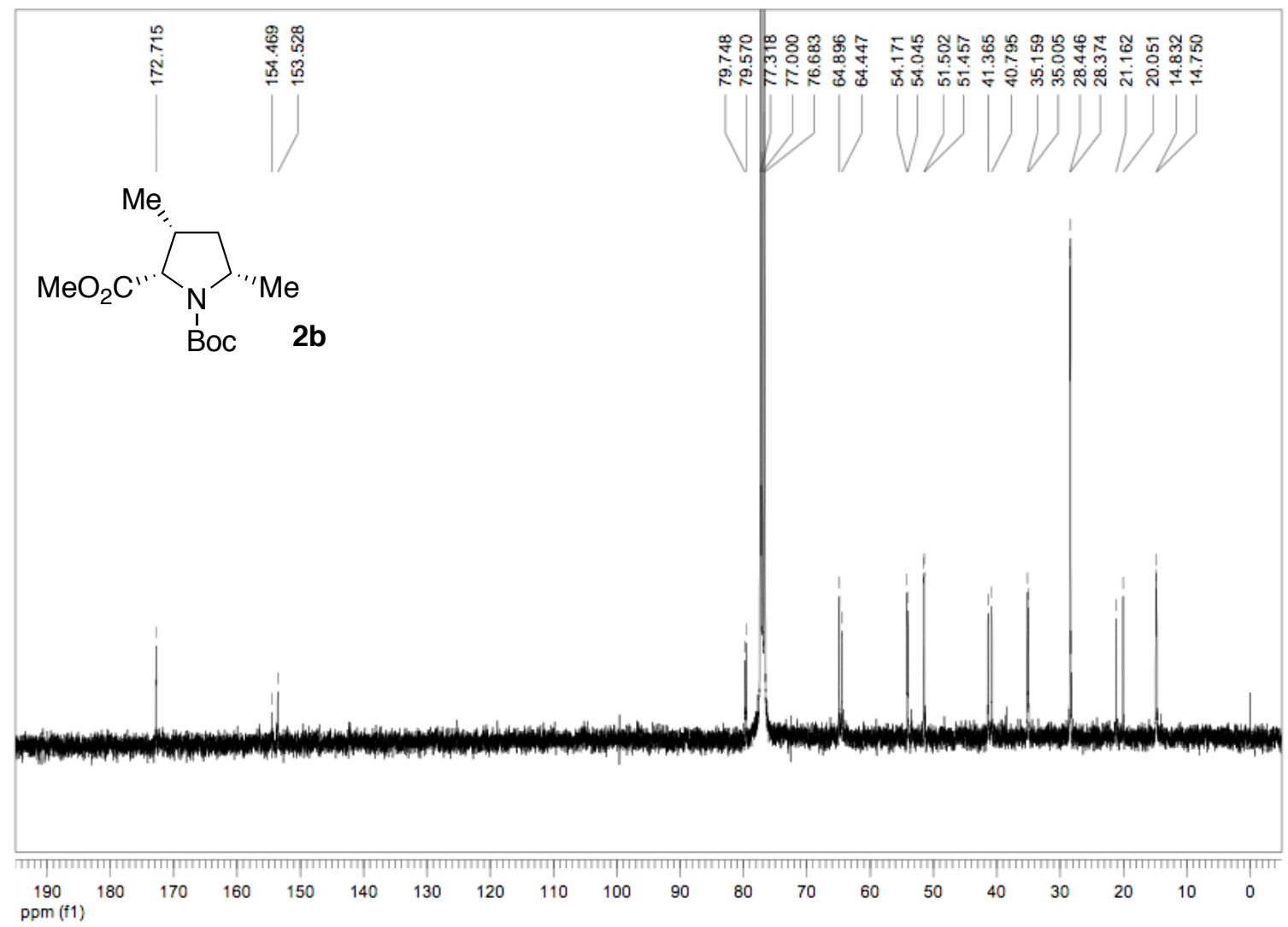

Figure S-26. ${ }^{13} \mathrm{C}\left\{{ }^{1} \mathrm{H}\right\}$ NMR spectrum of $\mathbf{2 b}$. 


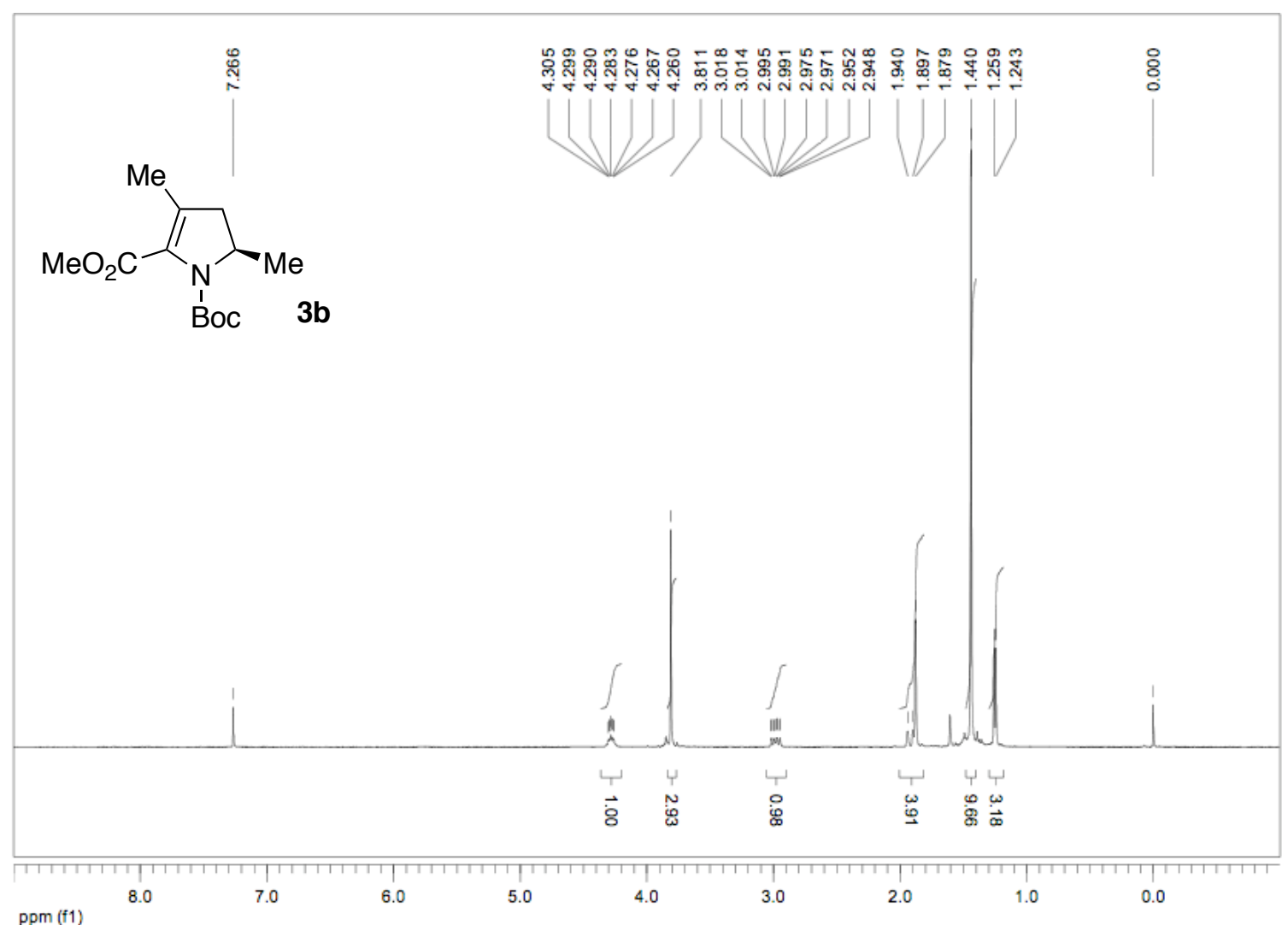

Figure S-27. ${ }^{1} \mathrm{H}$ NMR spectrum of $\mathbf{3 b}$.

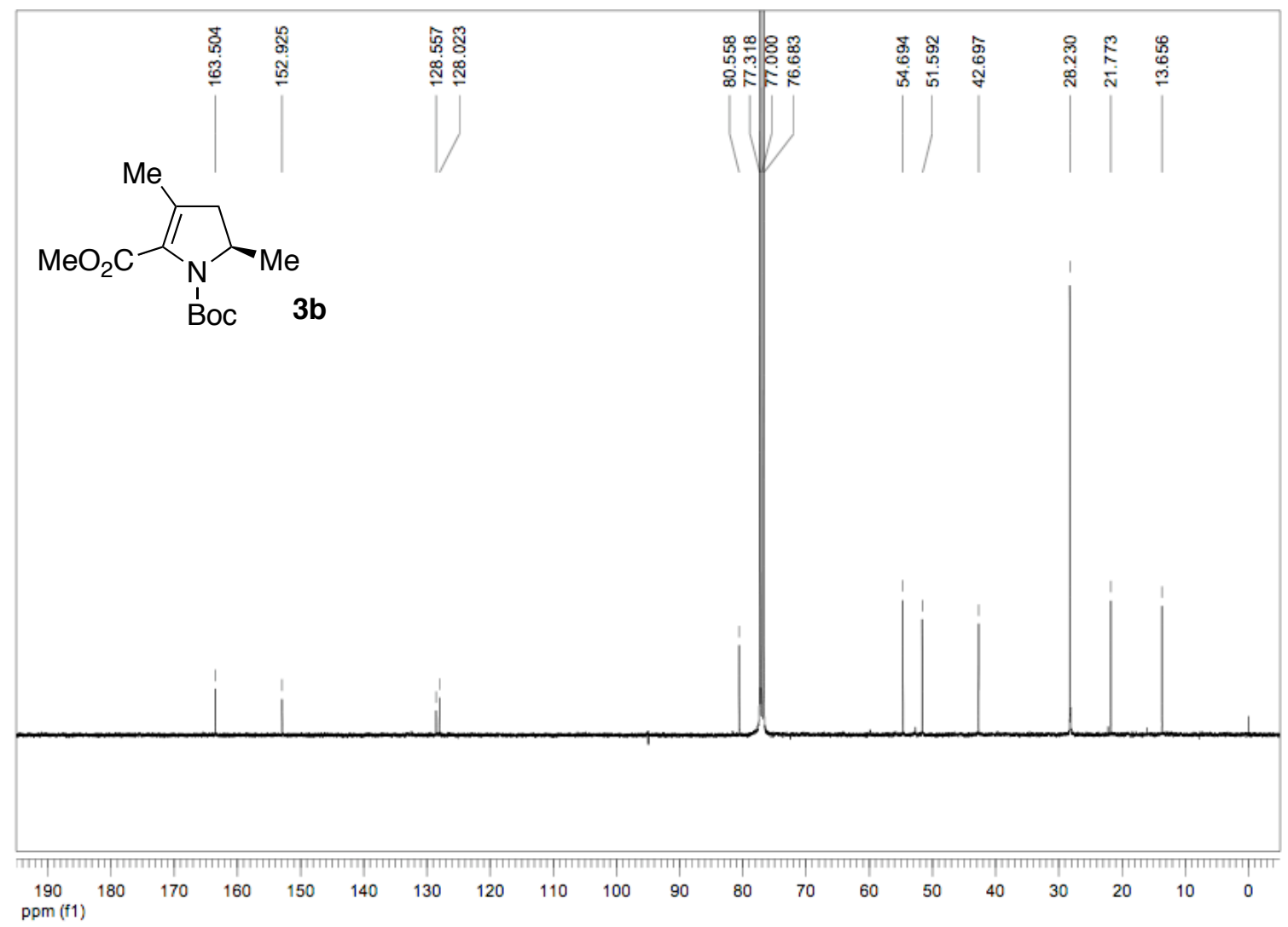

Figure S-28. ${ }^{13} \mathrm{C}\left\{{ }^{1} \mathrm{H}\right\}$ NMR spectrum of $\mathbf{3 b}$. 


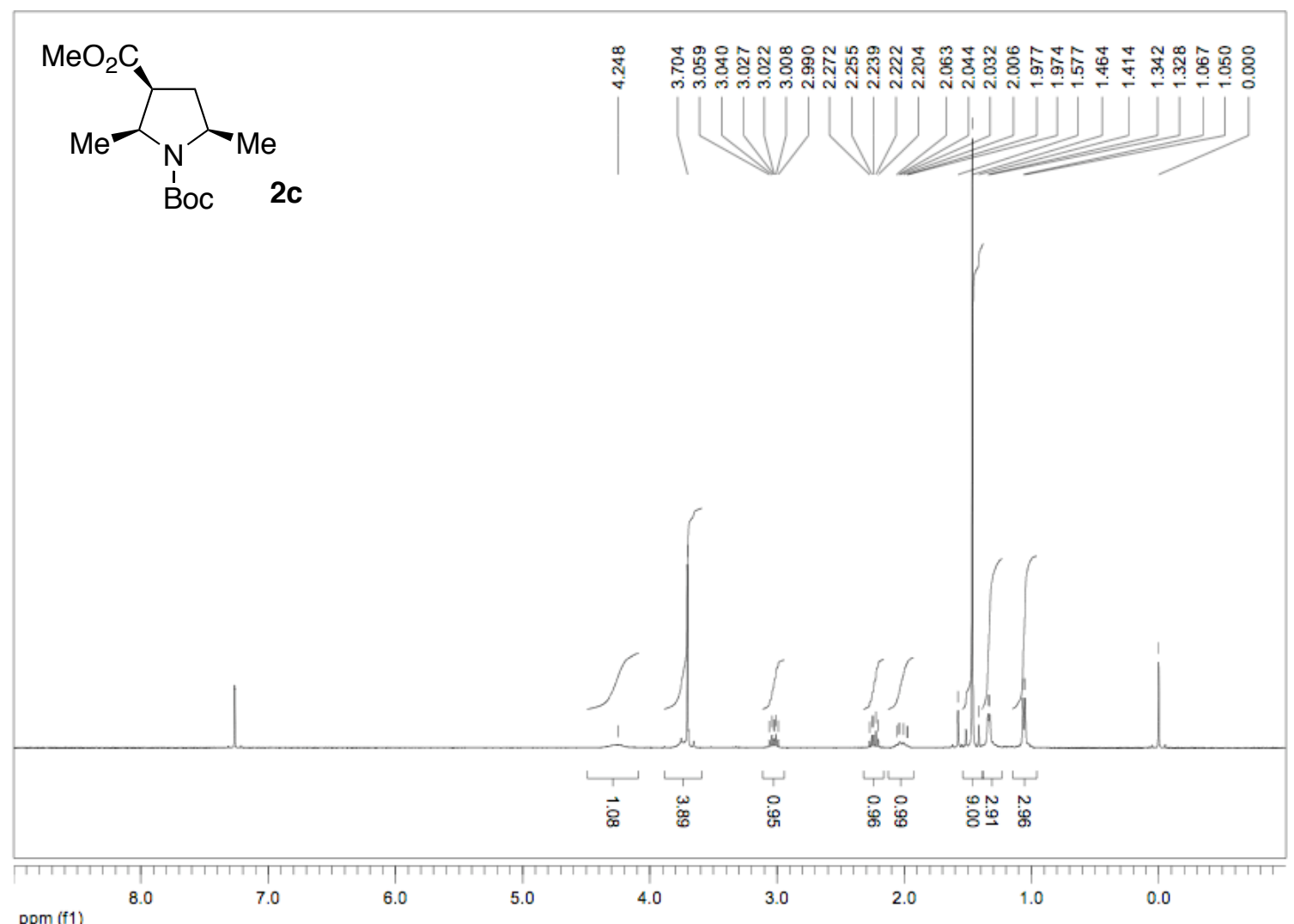

Figure S-29. $\quad{ }^{1} \mathrm{H}$ NMR spectrum of $\mathbf{2 c}$.

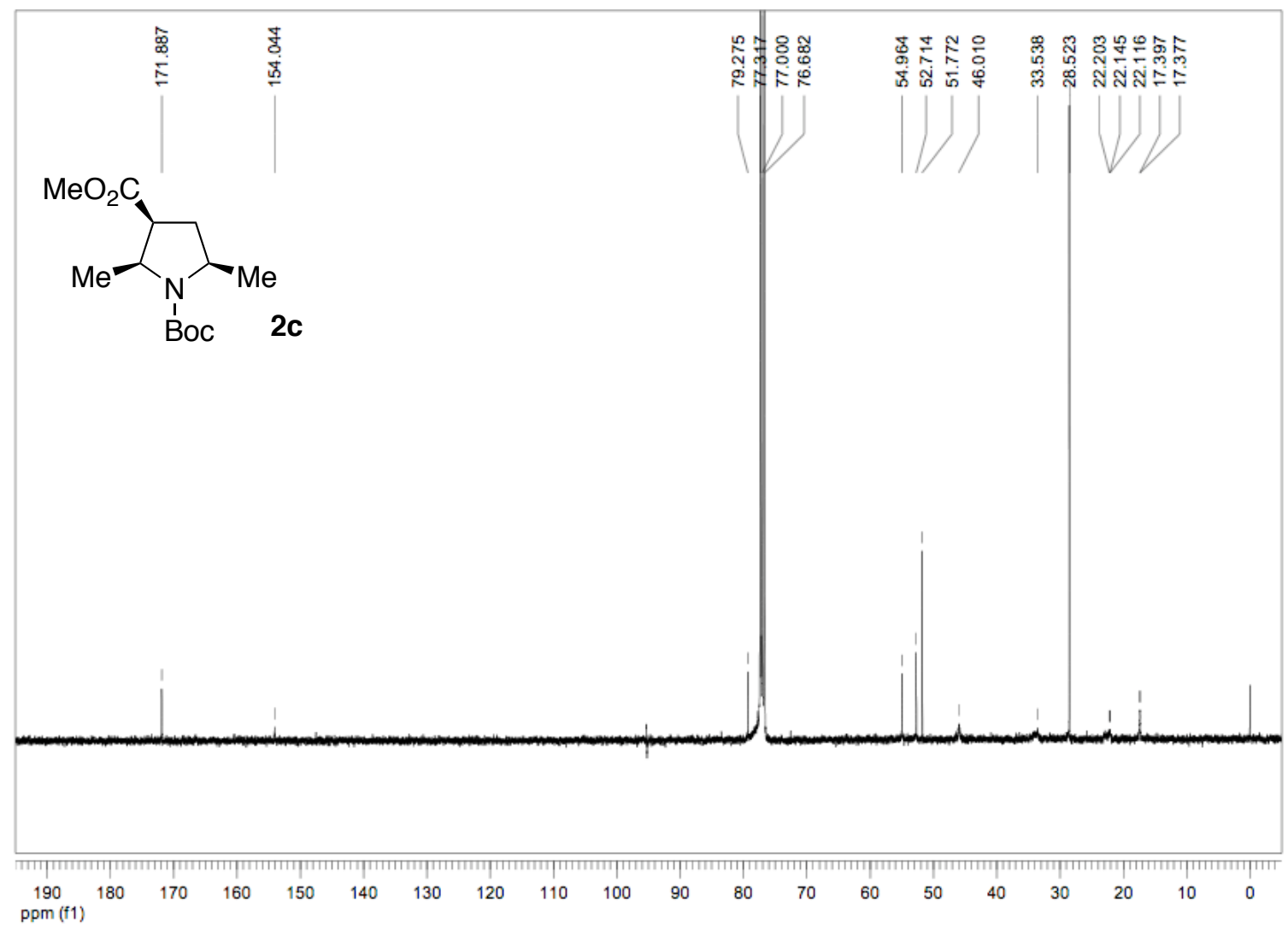

Figure S-30. ${ }^{13} \mathrm{C}\left\{{ }^{1} \mathrm{H}\right\}$ NMR spectrum of 2c. 


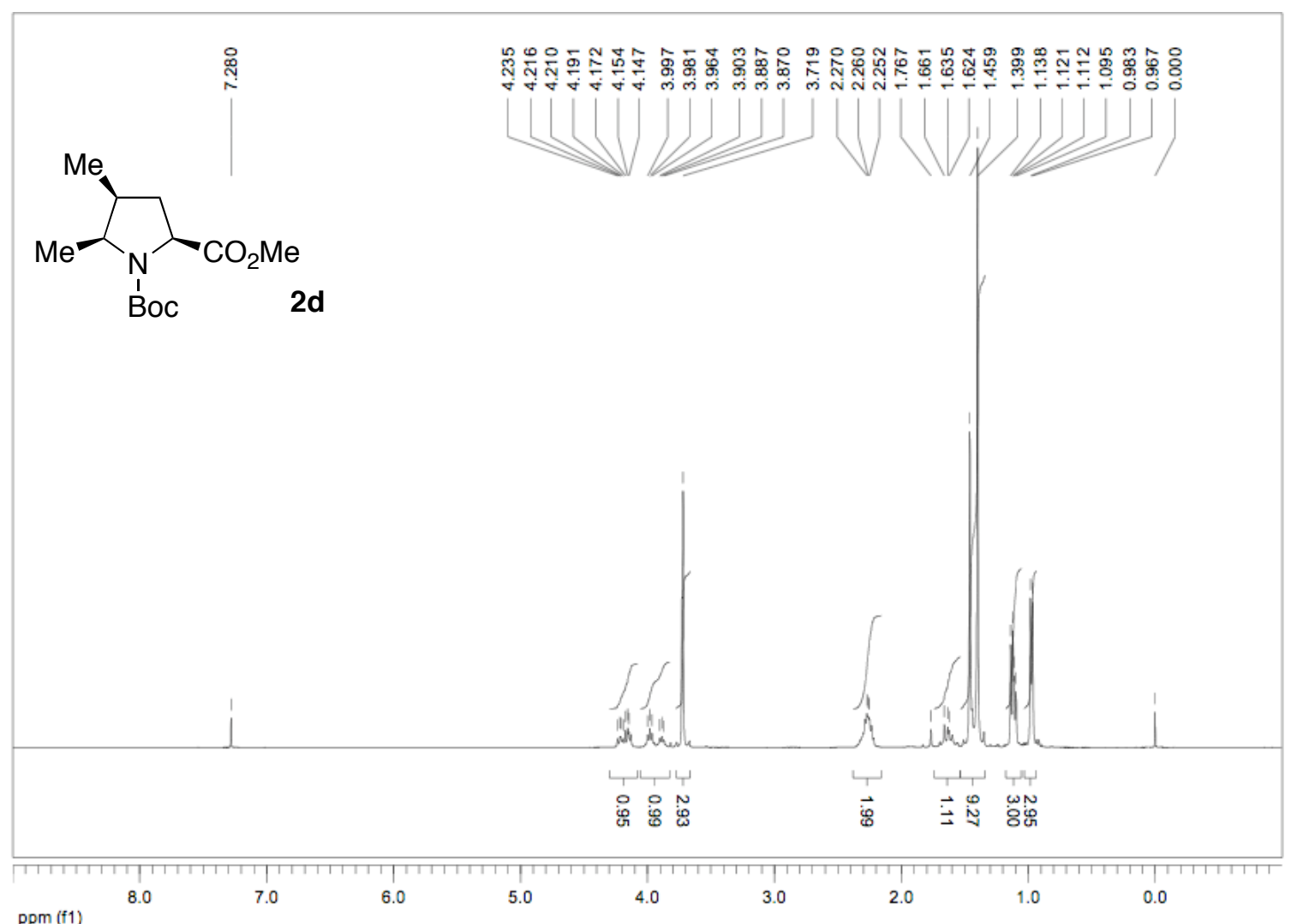

Figure S-31. $\quad{ }^{1}$ H NMR spectrum of $\mathbf{2 d}$.

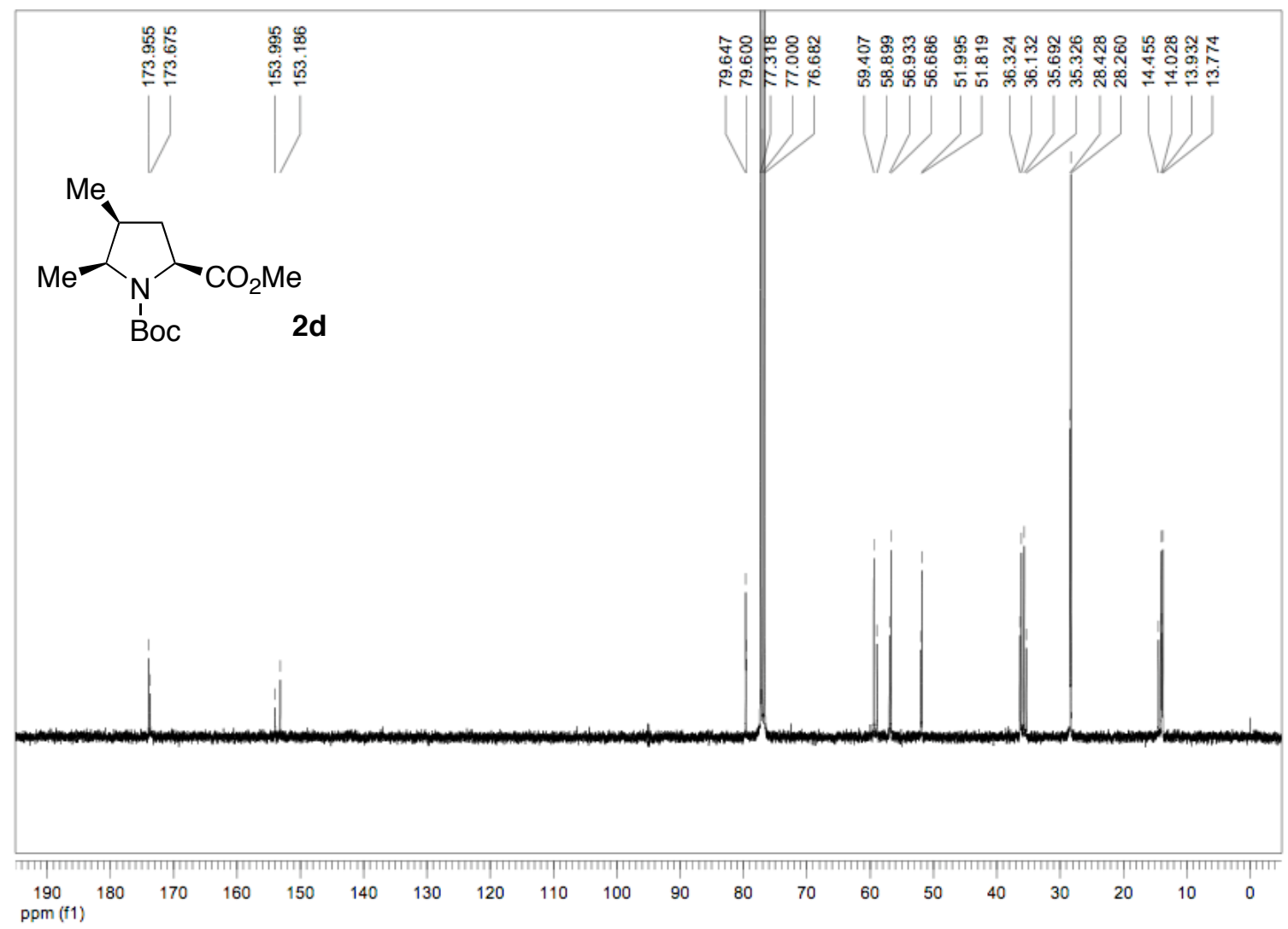

Figure S-32. ${ }^{13} \mathrm{C}\left\{{ }^{1} \mathrm{H}\right\}$ NMR spectrum of 2d. 


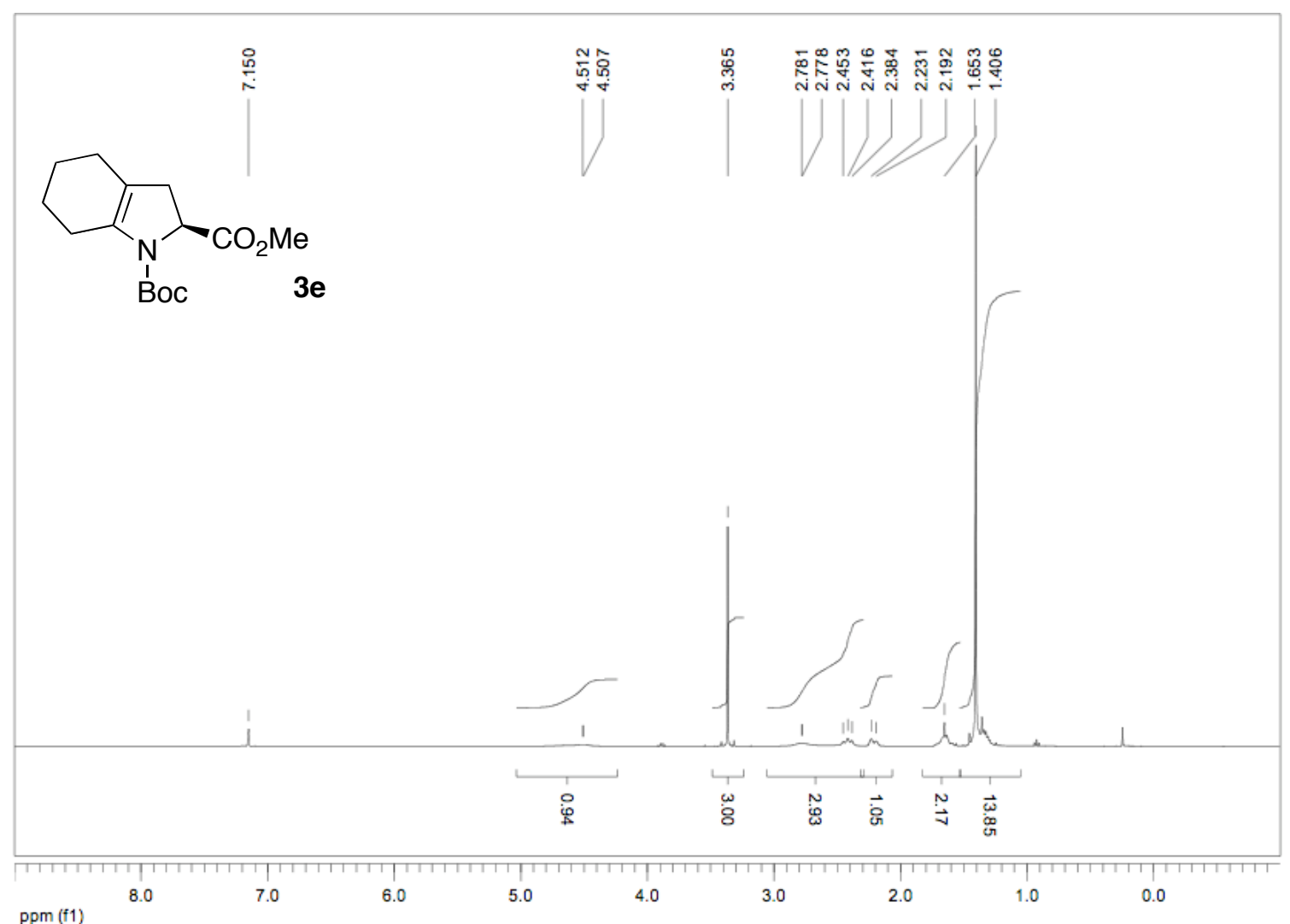

Figure S-33. $\quad{ }^{1} \mathrm{H}$ NMR spectrum of $\mathbf{3 e}$.

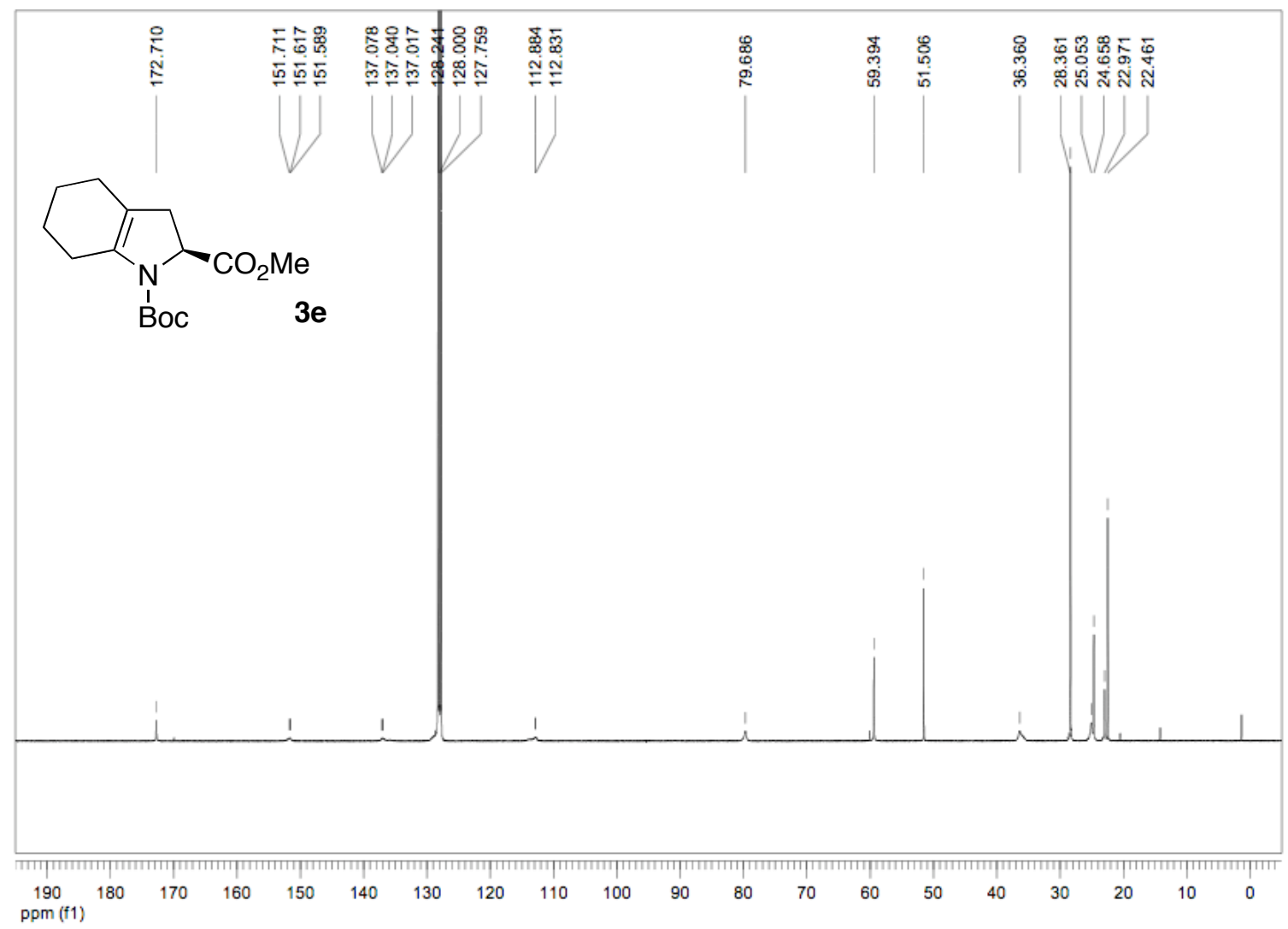

Figure S-34. ${ }^{13} \mathrm{C}\left\{{ }^{1} \mathrm{H}\right\}$ NMR spectrum of $\mathbf{3 e}$. 


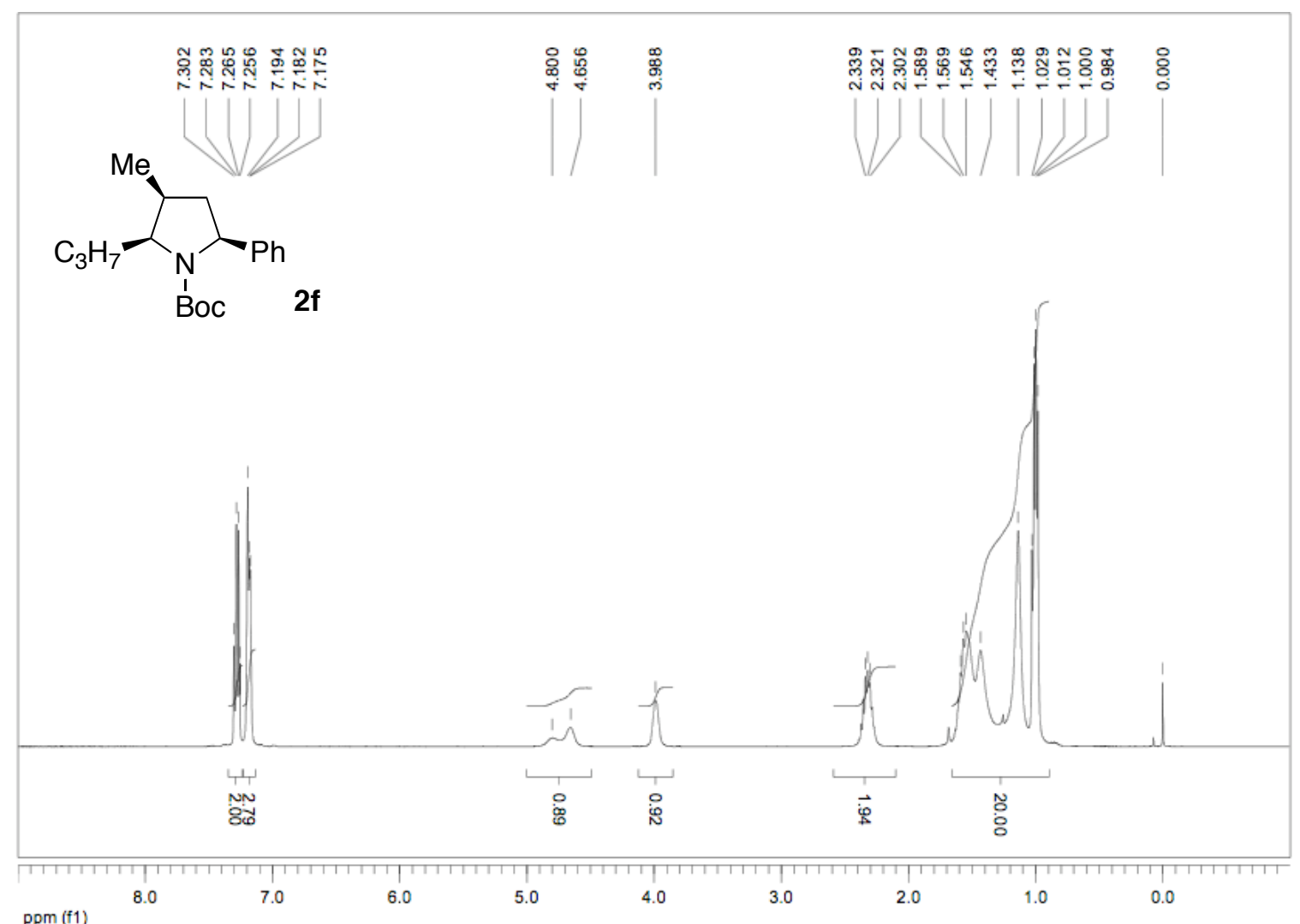

Figure S-35. $\quad{ }^{1} \mathrm{H}$ NMR spectrum of $\mathbf{2 f}$.

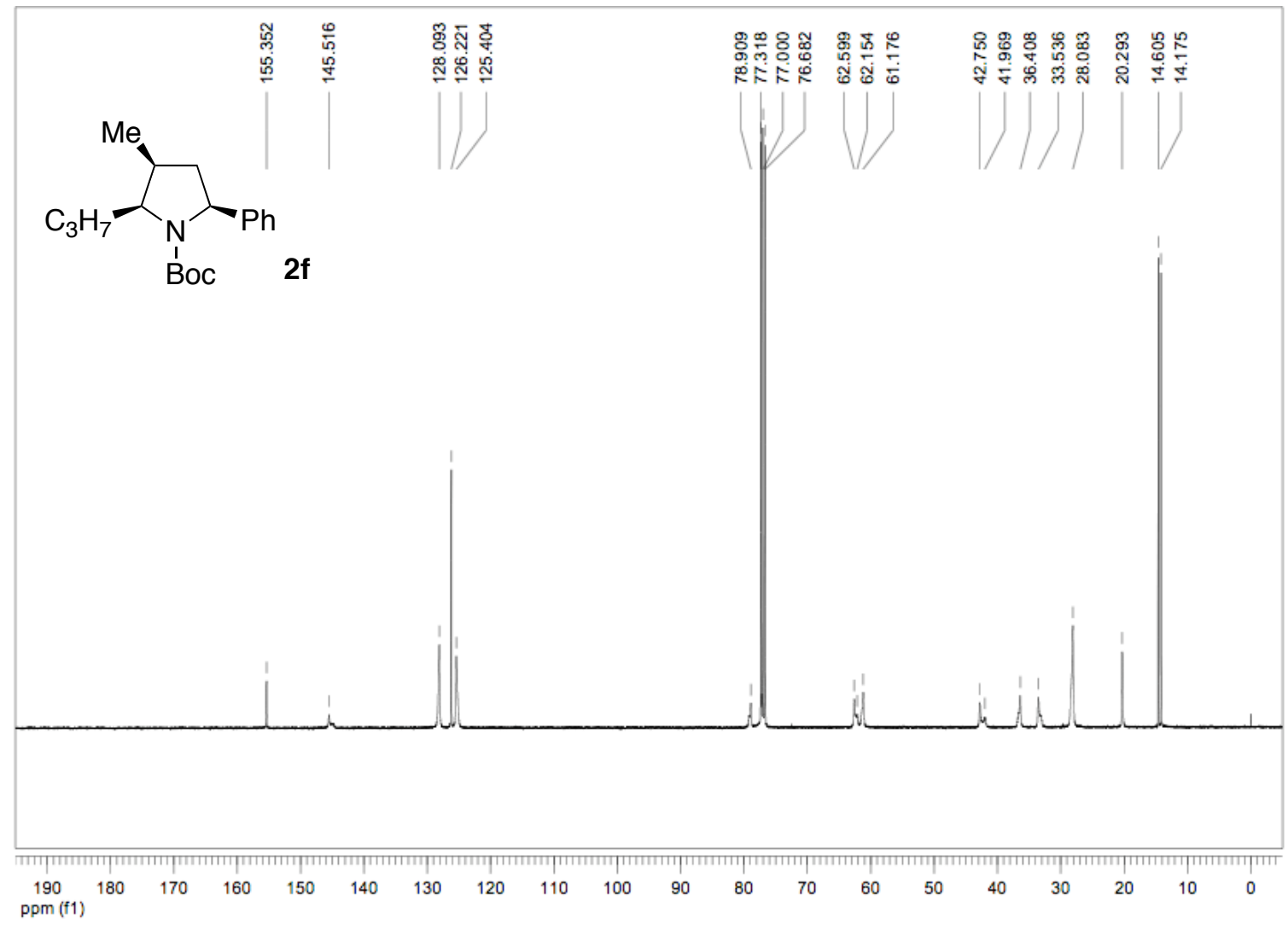

Figure S-36. ${ }^{13} \mathrm{C}\left\{{ }^{1} \mathrm{H}\right\}$ NMR spectrum of $\mathbf{2 f}$. 


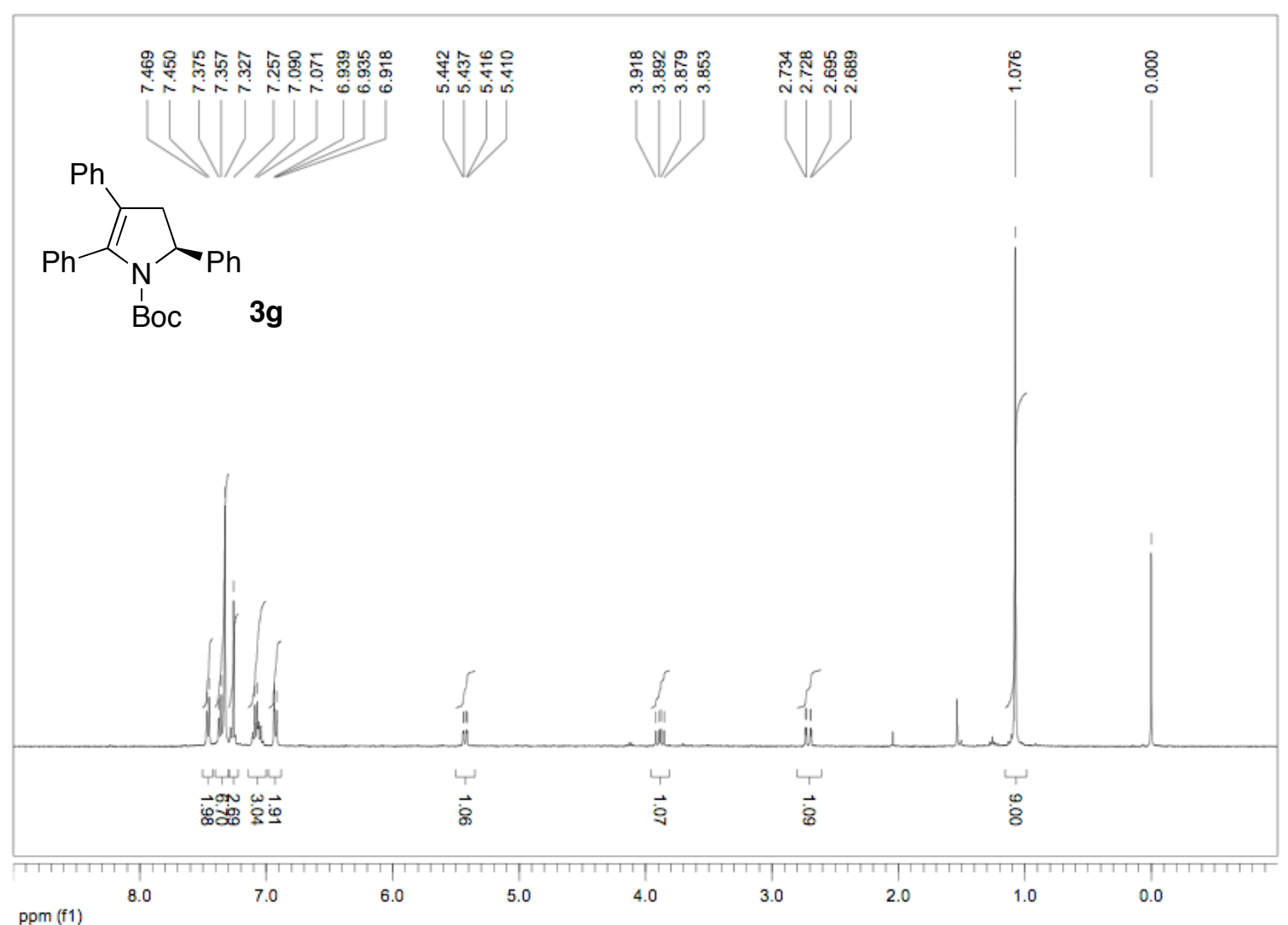

Figure S-37. ${ }^{1} \mathrm{H}$ NMR spectrum of $\mathbf{3 g}$.

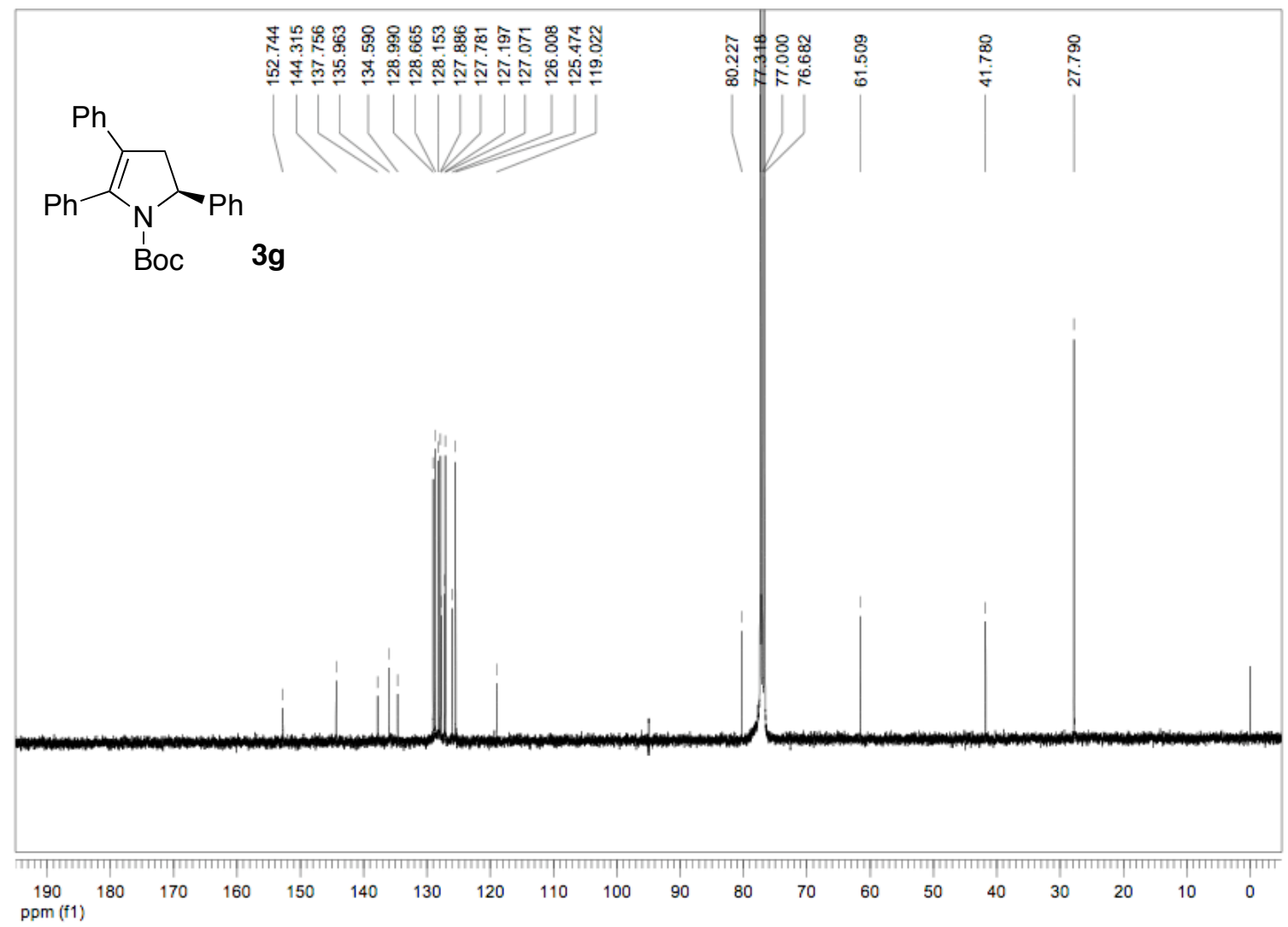

Figure S-38. ${ }^{13} \mathrm{C}\left\{{ }^{1} \mathrm{H}\right\}$ NMR spectrum of $\mathbf{3 g}$. 


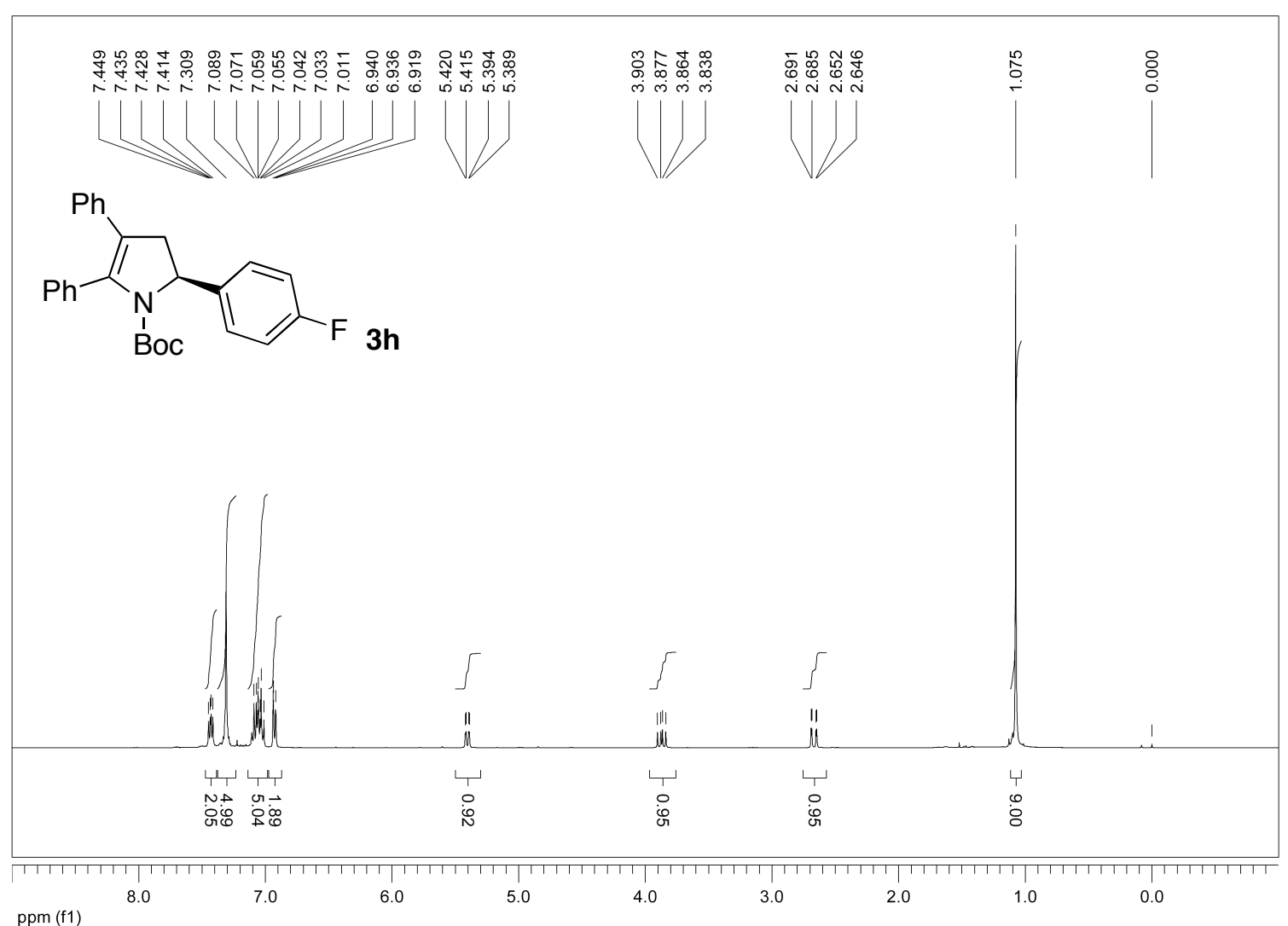

Figure S-39. ${ }^{1}$ H NMR spectrum of $\mathbf{3 h}$.

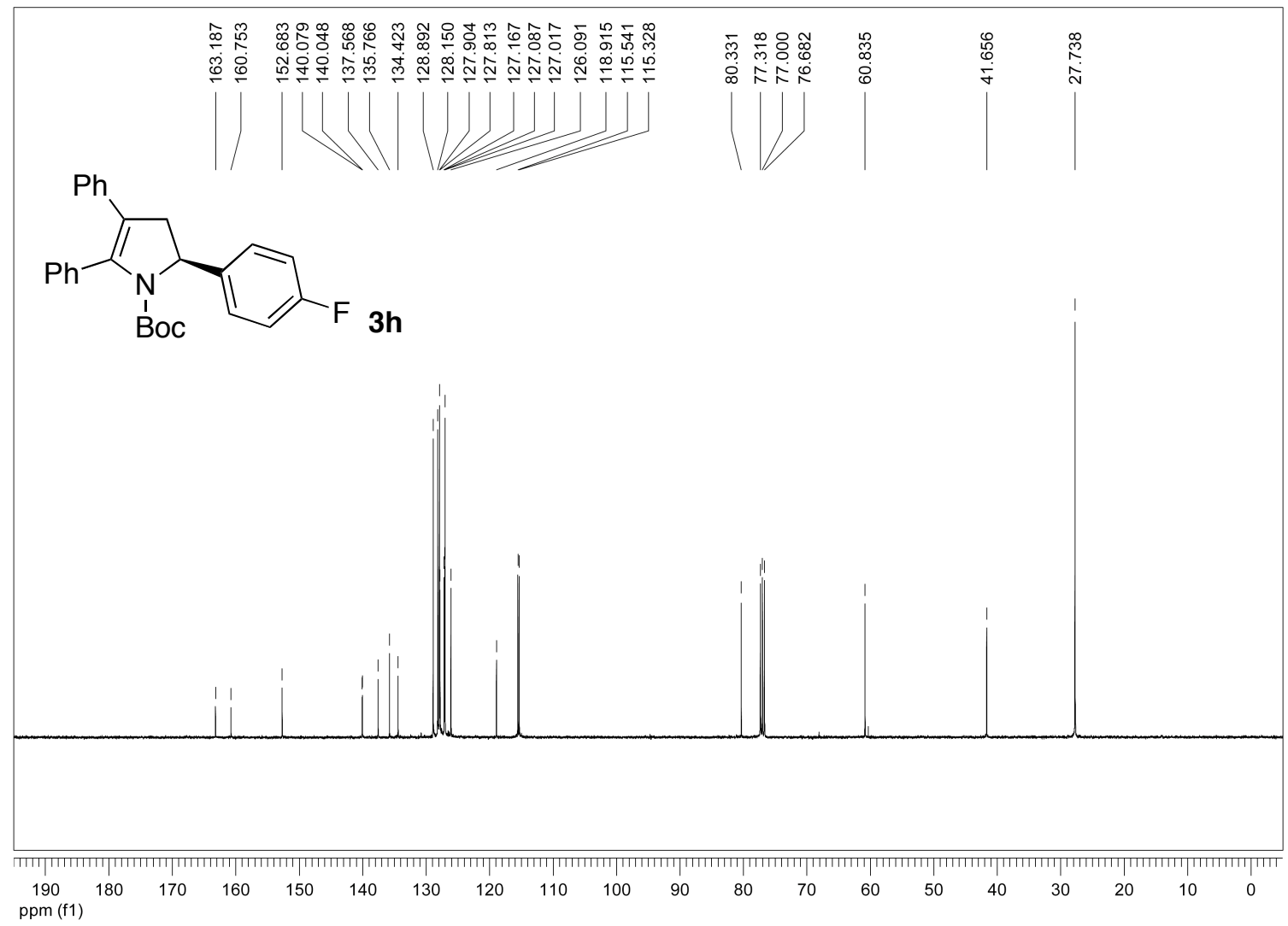

Figure S-40. ${ }^{13} \mathrm{C}\left\{{ }^{1} \mathrm{H}\right\}$ NMR spectrum of $\mathbf{3 h}$. 


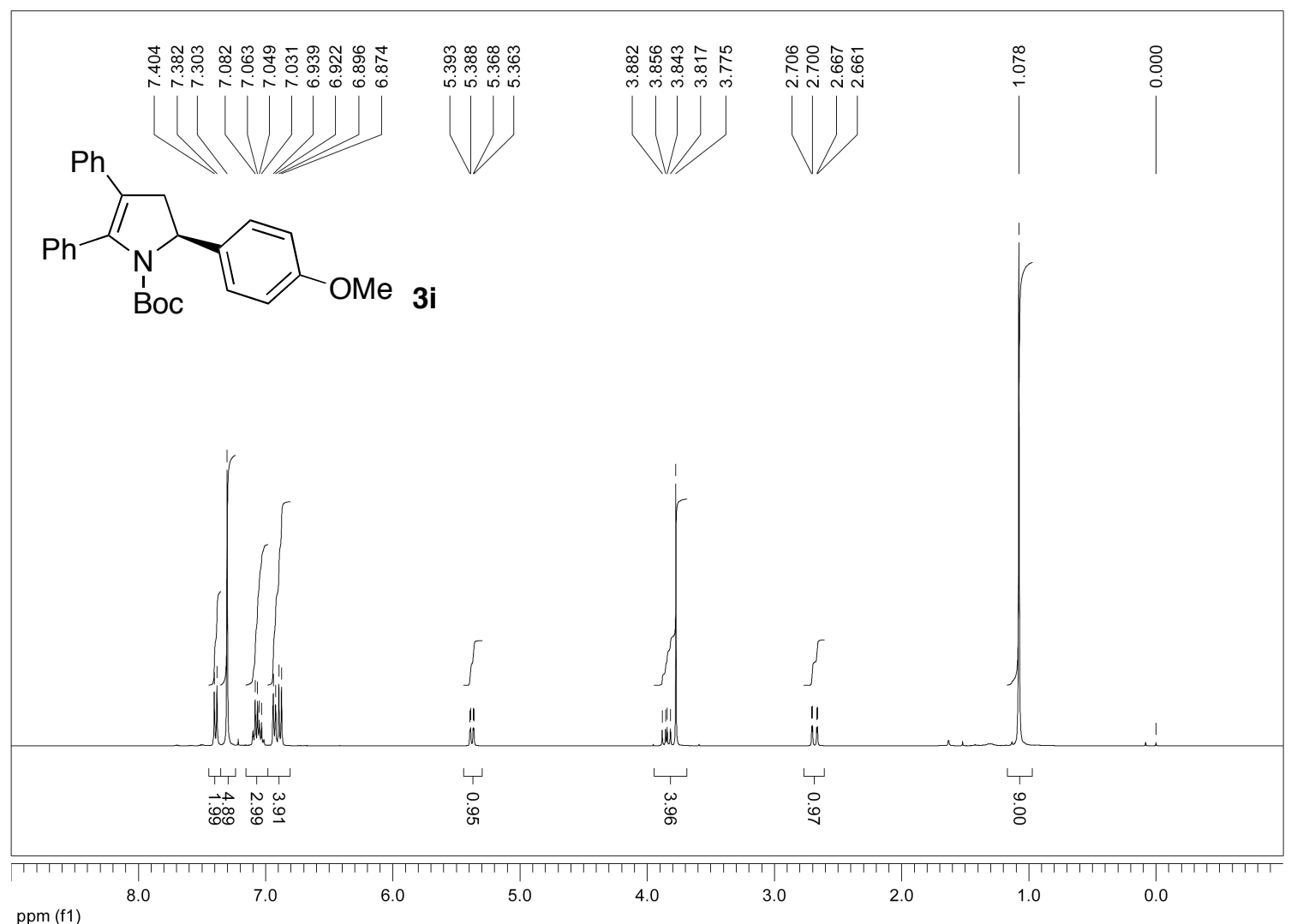

Figure S-41. ${ }^{1}$ H NMR spectrum of $3 \mathbf{3}$.

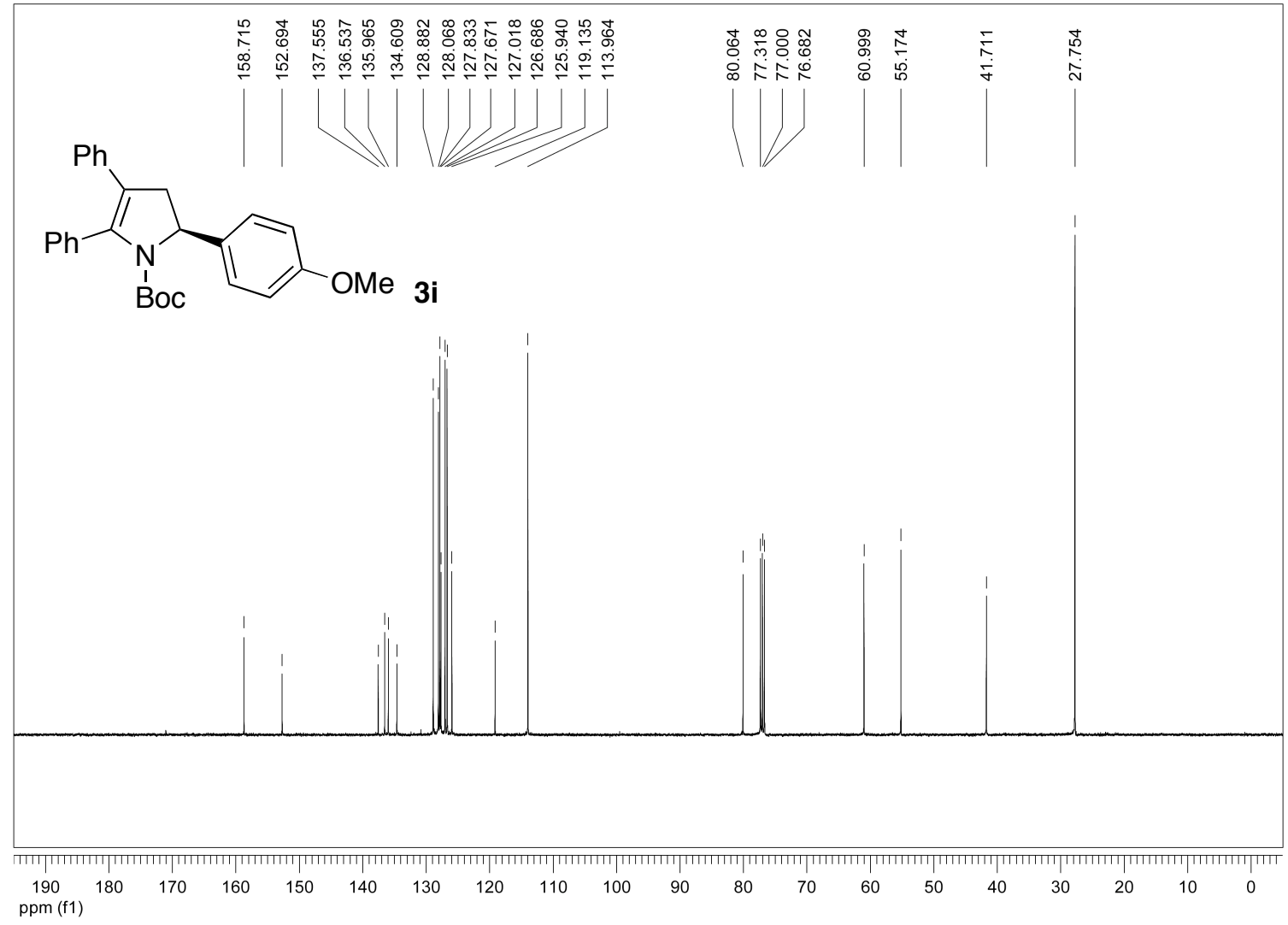

Figure S-42. ${ }^{13} \mathrm{C}\left\{{ }^{1} \mathrm{H}\right\}$ NMR spectrum of $3 \mathbf{i}$. 


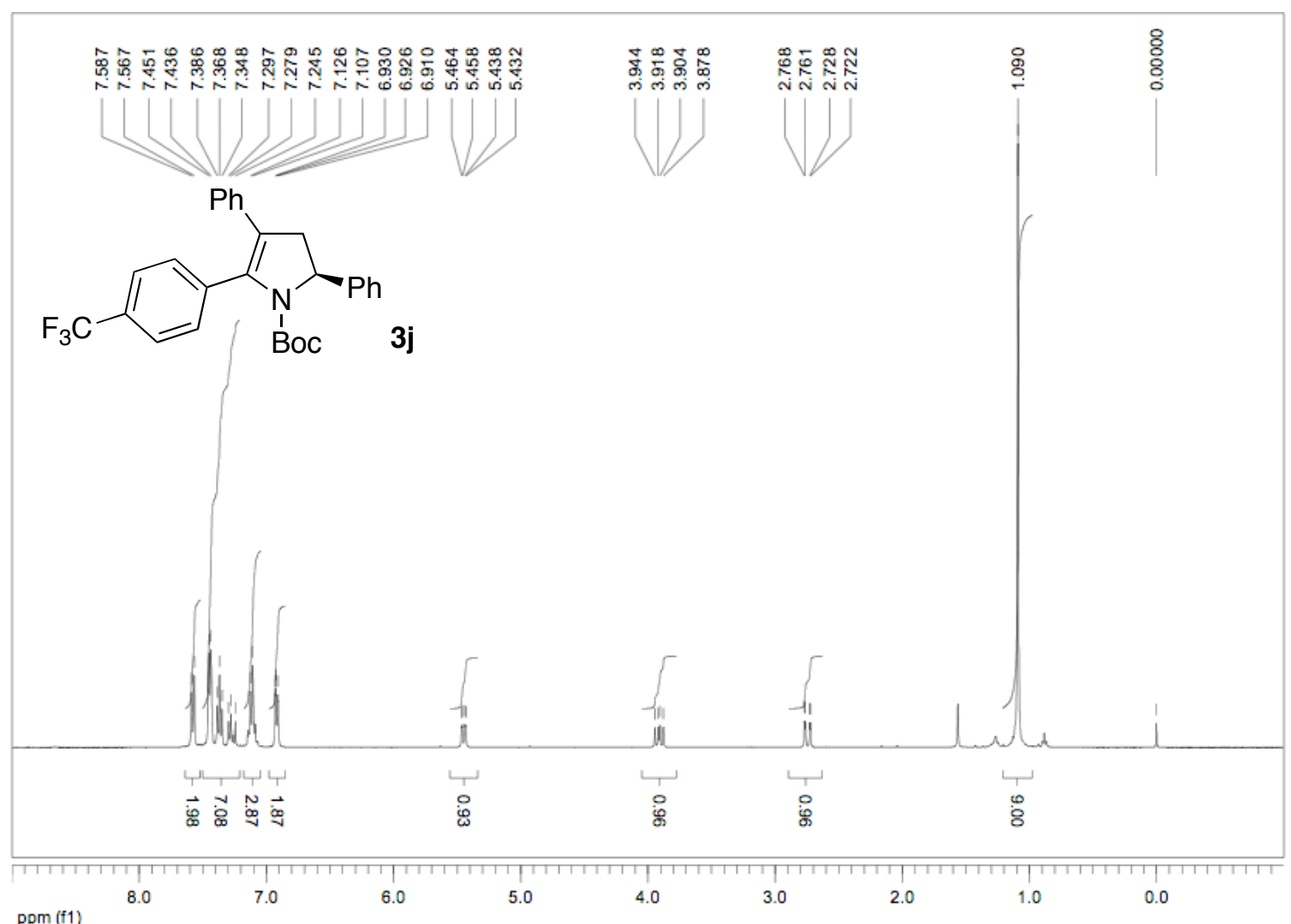

Figure S-43. $\quad{ }^{1}$ H NMR spectrum of $\mathbf{3 j}$.

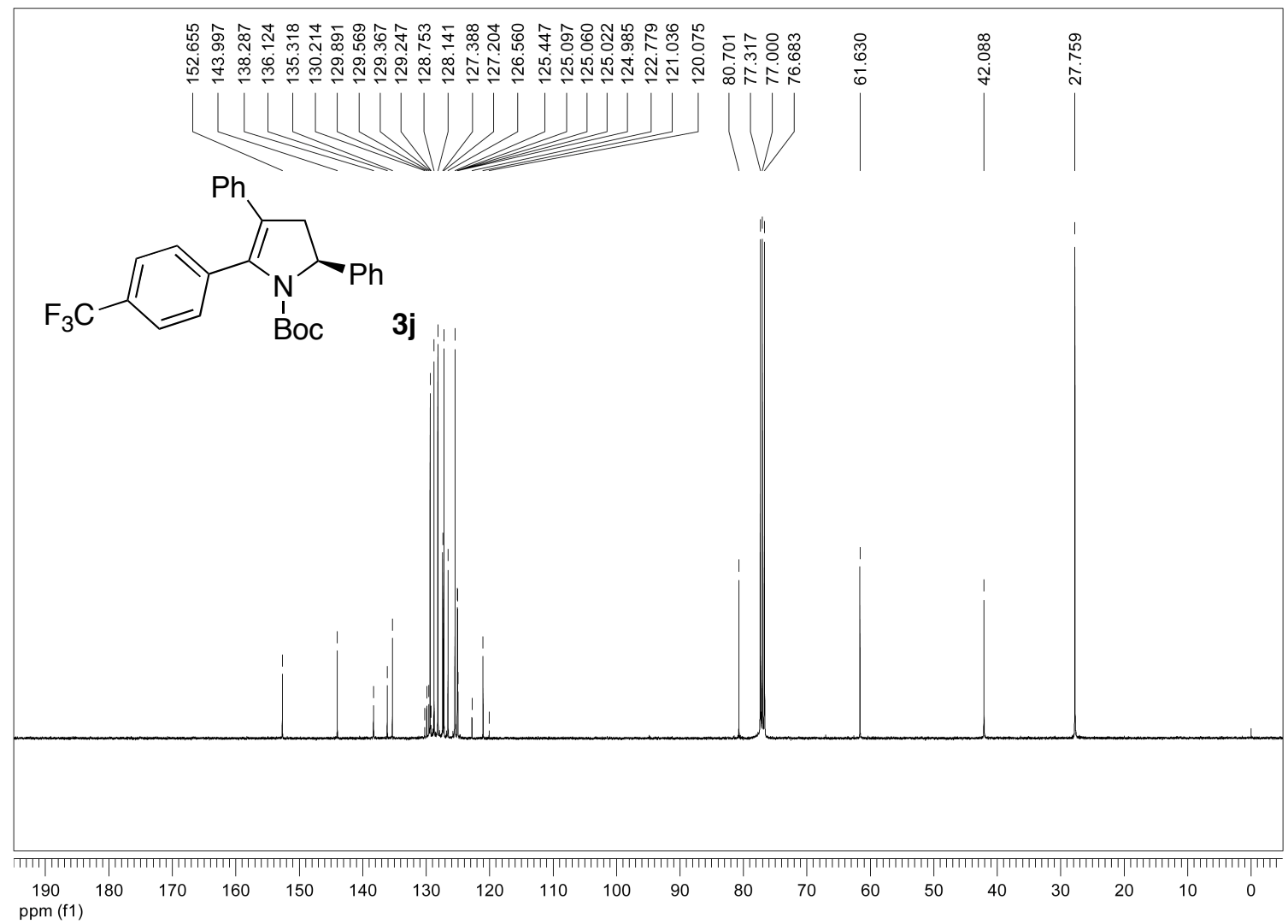

Figure S-44. ${ }^{13} \mathrm{C}\left\{{ }^{1} \mathrm{H}\right\}$ NMR spectrum of $\mathbf{3 j}$. 


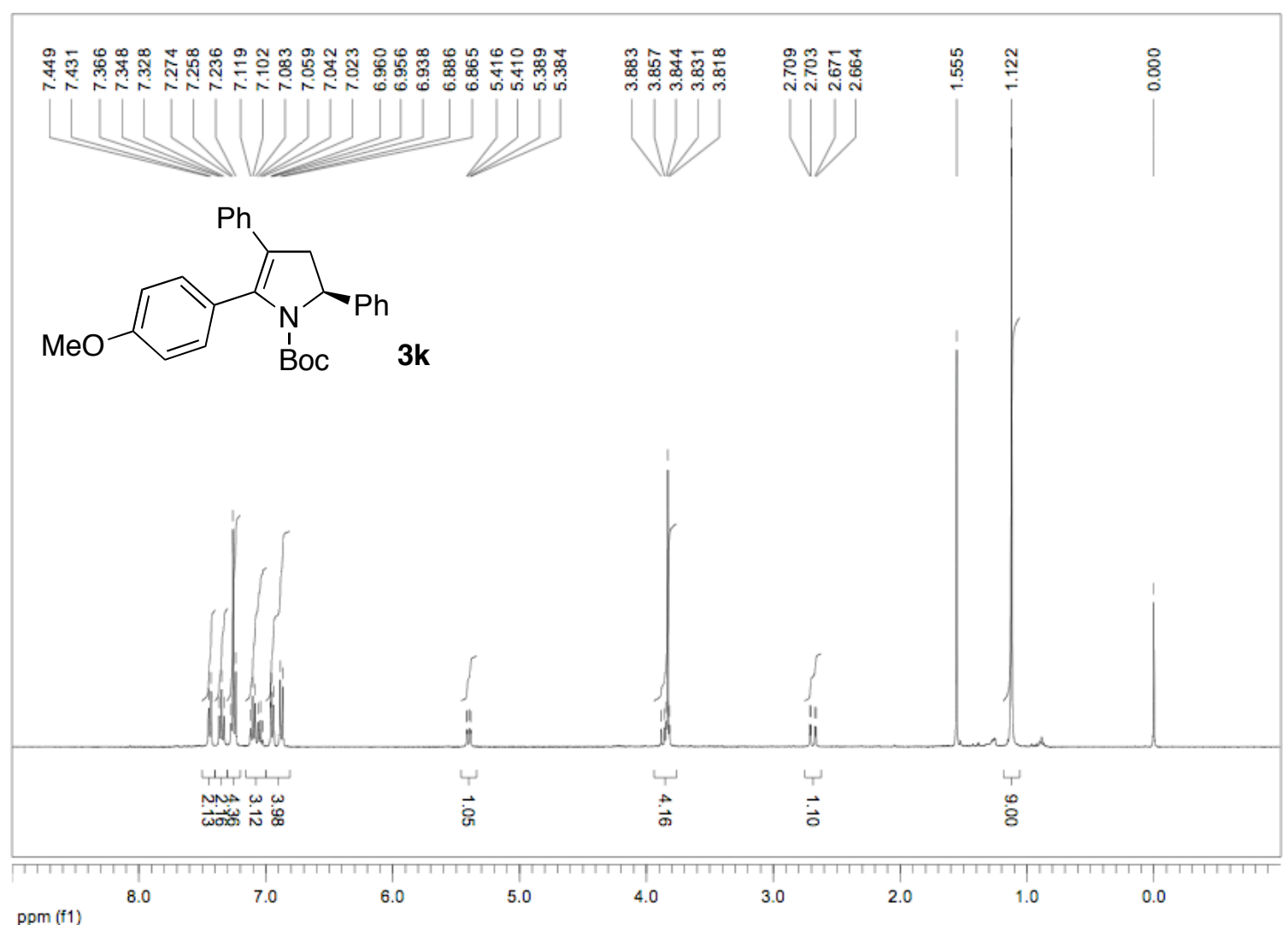

Figure S-45. $\quad{ }^{1} \mathrm{H}$ NMR spectrum of $\mathbf{3 k}$.

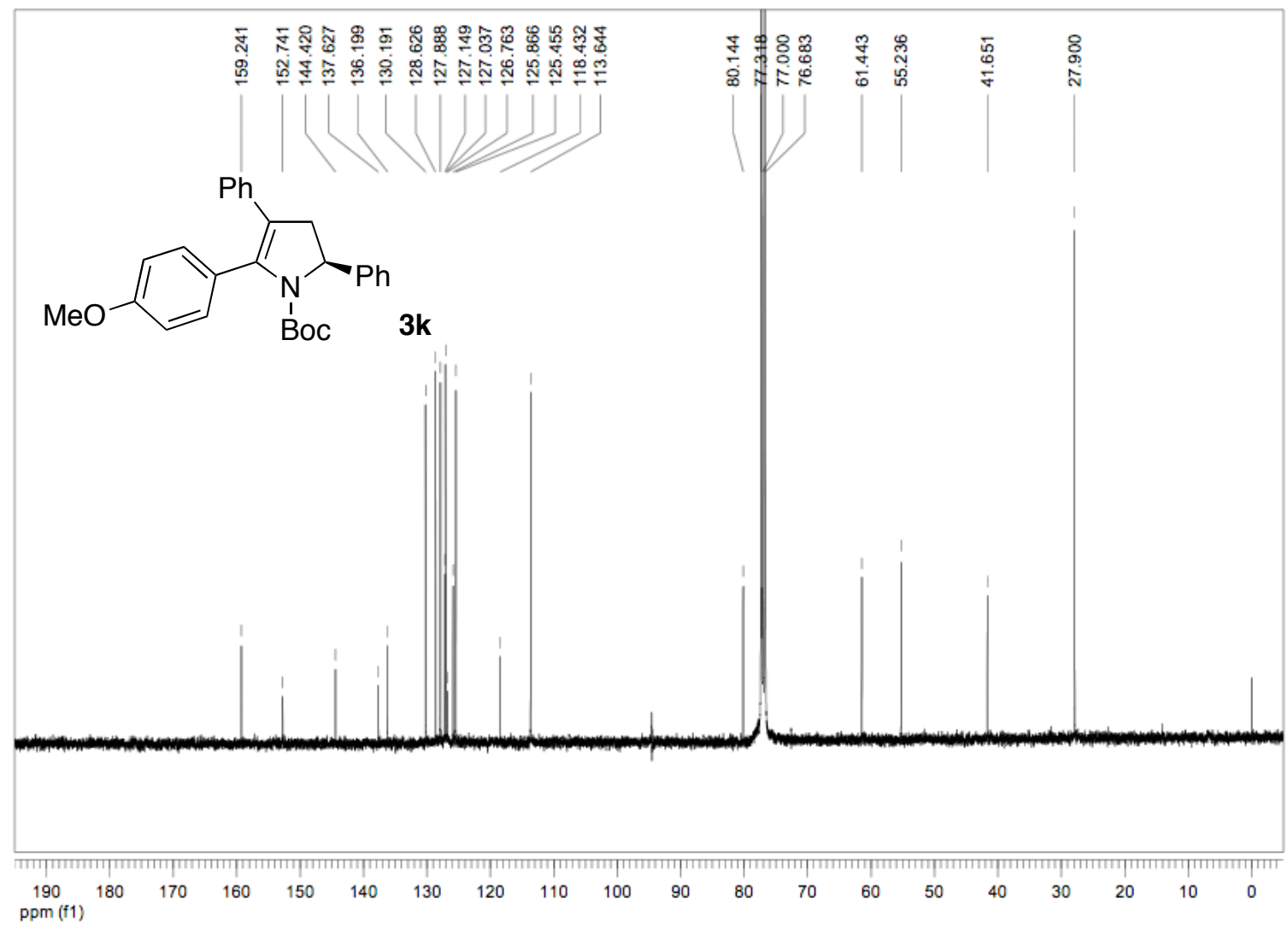

Figure S-46. ${ }^{13} \mathrm{C}\left\{{ }^{1} \mathrm{H}\right\}$ NMR spectrum of $\mathbf{3 k}$. 